\title{
Modular transcriptional repertoire and MicroRNA target analyses characterize genomic dysregulation in the thymus of Down syndrome infants
}

\author{
Carlos Alberto Moreira-Filho', Silvia Yumi Bando², Fernanda Bernardi Bertonha ${ }^{3}$, \\ Filipi Nascimento Silva ${ }^{4}$, Luciano da Fontoura Costa ${ }^{5}$, Leandro Rodrigues Ferreira ${ }^{6}$, \\ Glaucio Furlanetto7, Paulo Chacur ${ }^{8}$, Maria Claudia Nogueira Zerbini ${ }^{9}$ and Magda \\ Carneiro-Sampaio ${ }^{10}$ \\ ${ }^{1}$ Departamento de Pediatria, Faculdade de Medicina da Universidade de São Paulo, São Paulo, SP, Brasil \\ 2 Departamento de Pediatria, Faculdade de Medicina da Universidade de São Paulo, São Paulo, SP, Brasil \\ ${ }^{3}$ Departamento de Pediatria, Faculdade de Medicina da Universidade de São Paulo, São Paulo, SP, Brasil \\ ${ }^{4}$ Instituto de Física de São Carlos, Universidade de São Paulo, São Carlos, SP, Brasil \\ ${ }^{5}$ Instituto de Física de São Carlos, Universidade de São Paulo, São Carlos, SP, Brasil \\ ${ }^{6}$ Departamento de Pediatria, Faculdade de Medicina da Universidade de São Paulo, São Paulo, SP, Brasil \\ 7 Instituto Dante Pazzanese de Cardiologia, São Paulo, SP, Brasil \\ ${ }^{8}$ Instituto Dante Pazzanese de Cardiologia, São Paulo, SP, Brasil \\ 9 Departamento de Patologia, Faculdade de Medicina da Universidade de São Paulo, São Paulo, SP, Brasil \\ ${ }^{10}$ Departamento de Pediatria, Faculdade de Medicina da Universidade de São Paulo, São Paulo, SP, Brasil \\ Correspondence to: Carlos Alberto Moreira-Filho, email: carlos.moreira@hc.fm.usp.br \\ Keywords: thymus, Down syndrome, gene coexpression network, modular transcriptional repertoire, microRNA, Pathology Section \\ Received: October 02, $2015 \quad$ Accepted: January 23, 2016 \\ Published: February 01, 2016
}

\section{ABSTRACT}

Trisomy 21-driven transcriptional alterations in human thymus were characterized through gene coexpression network (GCN) and miRNA-target analyses. We used whole thymic tissue - obtained at heart surgery from Down syndrome (DS) and karyotipically normal subjects (CT) - and a network-based approach for GCN analysis that allows the identification of modular transcriptional repertoires (communities) and the interactions between all the system's constituents through community detection. Changes in the degree of connections observed for hierarchically important hubs/genes in CT and DS networks corresponded to community changes. Distinct communities of highly interconnected genes were topologically identified in these networks. The role of miRNAs in modulating the expression of highly connected genes in CT and DS was revealed through miRNA-target analysis. Trisomy 21 gene dysregulation in thymus may be depicted as the breakdown and altered reorganization of transcriptional modules. Leading networks acting in normal or disease states were identified. CT networks would depict the "canonical" way of thymus functioning. Conversely, DS networks represent a "non-canonical" way, i.e., thymic tissue adaptation under trisomy $\mathbf{2 1}$ genomic dysregulation. This adaptation is probably driven by epigenetic mechanisms acting at chromatin level and through the miRNA control of transcriptional programs involving the networks' high-hierarchy genes.

\section{INTRODUCTION}

Thymus provides the specialized microenvironment for the proliferation, differentiation, T-cell antigen receptor (TCR) gene rearrangement and T-cell repertoire selection [1]. The thymic microenvironment encompasses thymic epithelial cells (TEC), fibroblasts, thymic myoid cells, and bone marrow-derived accessory cells such as B lymphocytes, macrophages and dendritic cells [2]. Therefore, T-cell developmental program involves cellular 
processes driven by coordinate changes in the expression of hundreds of genes in the thymus $[3,4,5,6]$.

In Down syndrome (DS) [7] the gene imbalance dosage involving the Down syndrome critical region in chromosome $21[8,9,10]$ determines a global genomic dysregulation and gene expression dysregulation domains (GEDDs) are found in discrete clusters along all chromosomes [11]. Thymic structural and functional abnormalities are among the phenotypic effects of such genomic dysregulation: DS patients present abnormal thymuses, characterized by lymphocyte depletion, cortical atrophy, and loss of corticomedullary limits. This long time recognized DS thymic abnormalities $[12,13]$ are not related to DS precocious senescence: DS immune system is intrinsically deficient from the very beginning [14]. This was recently confirmed by imaging studies. Sonographic thymic measurements showed that the majority of DS fetuses have smaller thymus than control [15]. Thymicthoracic ratio (TT-ratio) evaluations obtained through ultrasound examinations showed that fetuses with trisomy 21 have a small thymus, suggesting accelerated thymic involution in utero [16].

Measuring the total number of signal joint TCR excision circles per ml blood, Bloemers et al. [17] found out that DS thymus has a decreased thymic output, concluding that "reduced thymic output, but not reduced peripheral generation nor increased loss of naive T-cells, results in the low naive T-cell numbers found in DS". Studying the Ts65DN mouse model of DS, Lorenzo et al. [18] showed that immature thymocyte defects underlie immune dysfunction in DS and that increased oxidative stress and reduced cytokine signaling impair T-cell development. Since DS autoimmune diseases are more represented in DS, Pellegrini et al. [19] investigated phenotypic and functional alterations of natural $T$ regulatory cells (nTreg) in DS subjects and found an over-expressed peripheral nTreg population with a defective inhibitory activity, what may be correlated with autoimmunity in DS. On the other hand, insufficient thymic expression of AIRE and peripheral antigens has been reported in DS patients [20,21].

Global genomic dysregulation in DS also involves epigenetic mechanisms, as evidenced by the study of global changes and chromosome distribution characteristics of microRNA (miRNA) expression in lymphocytes and cord blood cells from DS children by high-throughput sequencing technology $[22,23]$. It was discovered that most of the overexpressed miRNAs in DS were not Hsa21-derived. Therefore, miRNA abnormal expression in DS should be probably associated with the dysregulation of disomic genes caused by trisomy 21 . Altogether, these works clearly show the importance of performing comparative global transcriptome and miRNAtarget analyses in the thymic tissue of DS and karyotypic normal (CT) subjects. Such analyses are mandatory to characterize gene coexpression network (GCN) changes that could better explain the mechanisms involved in DS thymic hypofunction.

In the present work we conducted GCN and miRNA studies in thymic tissue obtained at cardiac surgery from DS and CT subjects. We constructed GCNs for DS and CT groups, separately, obtaining the networks for differentially expressed genes (DS versus CT) and also for global gene expression in each group. We adopted a network-based approach for GCN analysis - fully described in the Material and Methods section - that allows the categorization of network nodes according to distinct hierarchical levels of gene-gene connections, or node degree, and of interconnection between node neighbors, or concentric node degree $[24,25]$. In a summarized way, there are three categories of high-hierarchy $(\mathrm{HH})$ genes: hubs are highly connected nodes, VIPs (or Very Important Persons) have low number of connections but connect only with hubs, and high-hubs have high number of connections with highly connected nodes [24]. Moreover, we were able to identify - by using network community detection and coarse-grained community structure methods [26] - all the transcriptional modules, i.e. the distinct gene communities, present in each GCN. The use of whole tissue coupled with community structure analysis of gene interaction networks is a strategy that has been adopted for circumventing tissue microdissection [26, 27].

The integration of the above mentioned methodologies permitted: i) the visualization and analysis of GCNs for differentially expressed GO annotated genes (DE networks) and for all valid annotated transcripts (CO networks); ii) the study of interactions between all the system's constituents based on community detection, that is, on modular transcriptional repertoire analysis [reviewed in 27 and 28], leading to the identification of co-dependent gene sets involved in common functional pathways; iii) miRNA target analyses for differentially expressed miRNAs, serving to investigate epigenetic mechanisms associated to thymic GCNs and, particularly, DS genomic dysregulation.

\section{RESULTS}

\section{GCN analyses}

In the DS versus CT comparison (SAM) all differentially expressed genes (538 genes) were found to be upregulated in the DS group. Coexpression networks for differentially expressed $\mathrm{GO}$ annotated genes (DE networks) were constructed for CT and DS groups based on gene-gene Pearson's correlation method. A 0.968 link-strength cut-off was adopted for CT-DE network and a 0.960 link-strength cut-off was adopted for DS-DE network. The resulting DE networks had 236 genes and 908 links for CT group and 300 genes and 629 links for DS 
group. A 0.994 link-strength cut-off was adopted for CO networks. CT-CO presented 4,577 nodes and 8,847 edges, while DS-CO presented 5,257 nodes and 8,952 edges. All networks had scale-free node degree distribution as shown in Figure 1A and 1B for CT-DE and DS-DE networks, respectively, and in Figures $2 \mathrm{~A}$ and $2 \mathrm{~B}$ for $\mathrm{CT}-\mathrm{CO}$ and DS-CO networks, respectively. Node categorization (hubs, VIPs, high-hubs) was accomplished using the usual node degree $(k 0)$ and the first neighborhood concentric node degree $(k 1)$, as previously described [24]. Node categorization is depicted in Figure $1 \mathrm{C}$ and $1 \mathrm{D}$ for CT$\mathrm{DE}$ and DS-DE networks, respectively and in Figure 2C and 2D for CT-CO and DS-CO networks, respectively. These categorizations and the gene functions for all highhierarchy genes $(\mathrm{HH})$ in CT and DS networks (DE and $\mathrm{CO}$ ) appear in Tables 1-4 and will be further discussed in following sections. Network connectivity was found to be lower in DS-DE network: 7.69 for CT-DE and 4.19 for DS-DE; and quite similar for both CO networks: 3.86 for CT-CO and 3.40 for DS-CO.

\section{A}
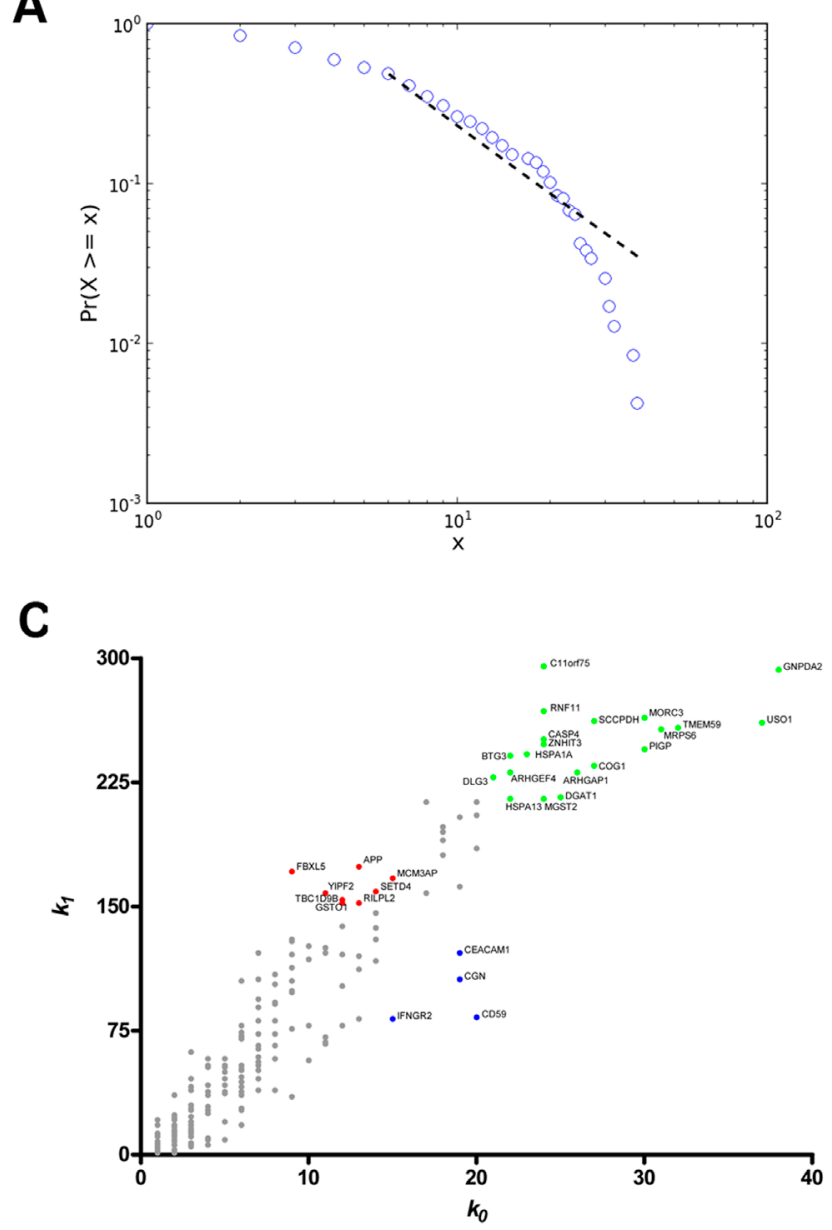

\section{Community detection}

An overall picture of $\mathrm{DE}$ and $\mathrm{CO}$ gene communities (modules) is depicted in Figure 3A and 3B for CT-DE and DS-DE networks, respectively and in Figure 3C and 3D for CT-CO and DS-CO networks, respectively. Different node colors identify the distinct gene communities in each network. Networks presented good quality of community structure and gene distribution. Modularity value was higher for DS-DE network: 0.705 against 0.450 for CT$\mathrm{DE}$, and quite similar between $\mathrm{CO}$ networks: 0.732 for CT-CO and 0.693 for DS-CO. The DE networks harbor the same number of communities (nine) but the DS network has lower connectivity and its communities are more sparsely connected, what may indicate a higher grade of dysregulation in cell's functional organization $[29,24]$. The CT-CO and DS-CO networks harbor 27 and 32 communities, respectively. The number of genes per community can be found in Tables $\mathrm{S} 1$ and $\mathrm{S} 2$, for DE and $\mathrm{CO}$ networks, respectively. A set of simulations run with slightly different link-strength thresholds (from 0.900 up

B

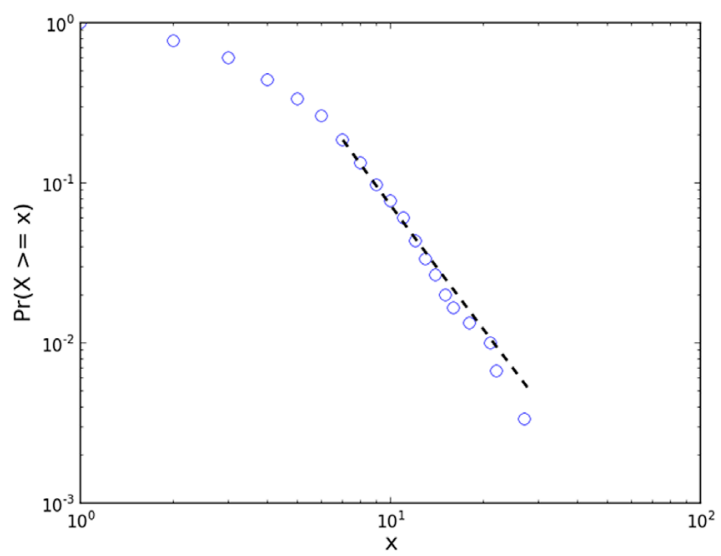

D

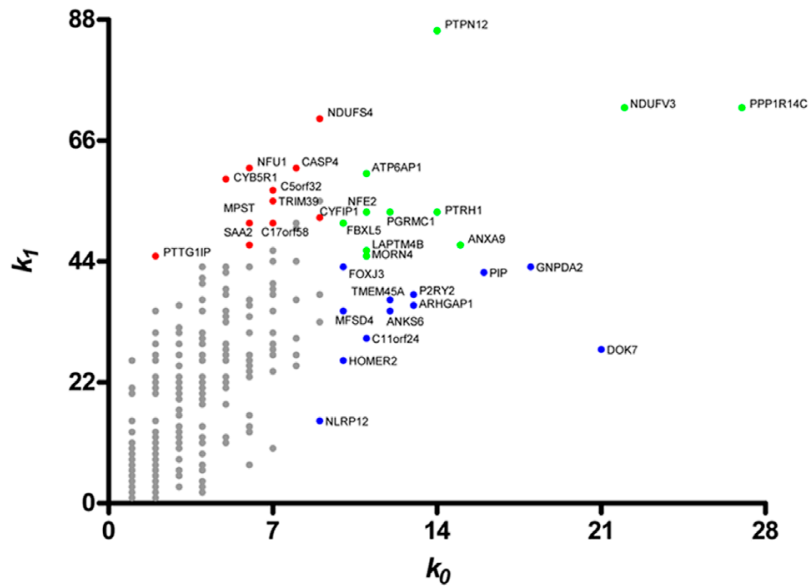

Figure 1: Node distribution and categorization for DE networks. Kolmogorov-Smirnov test for scale free status for CT-DE (A) and DS-DE (B) networks. Scatter plots of node degree (k0) vs concentric node degree (k1) measures of GO annotated genes in CT-DE (C) and DS-DE networks (D). Hubs (blue), VIPs (red) and high-hubs (green) are identified by their gene symbols. 
to 0.990 for DE networks, and from 0.980 up to 0.999 for CO networks) did not reveal alterations in community structures, thus indicating their robustness.

\section{Coarse-grained community structure analysis (DE and CO networks)}

Coarse-grained community structure (CGCS) was obtained for each network, yielding the relationships between each community in the network (Figure 4A and 4B for DE; 4C and 4D for CO). For CO networks only communities harboring $\mathrm{HH}$ genes were considered in this analysis. Connection weight values for $\mathrm{DE}$ and $\mathrm{CO}$ network's communities are depicted in Figure 5 and show the overall lower connection weight of DS networks' communities. Most of the DS-CO communities also presents lower connectivity values (Figure S1) when compared to CT-CO communities. Altogether, these measures indicate a certain degree of disorganization of inter and intra modular interactions, probably due to gene dosage imbalance.

\section{A}

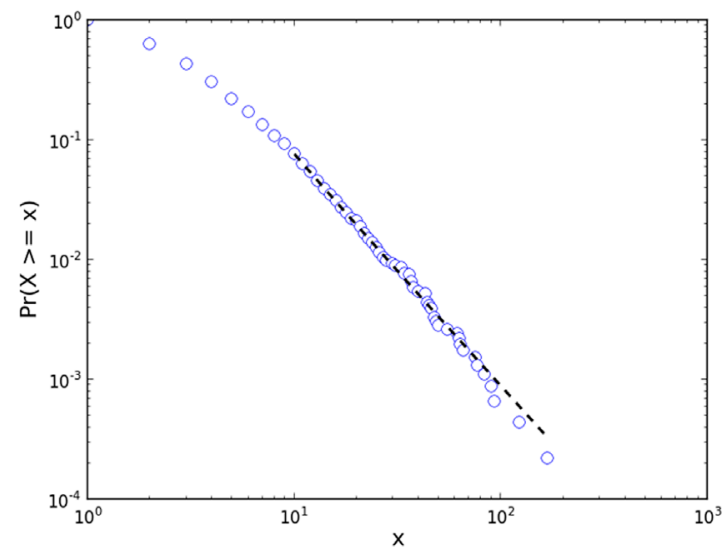

C

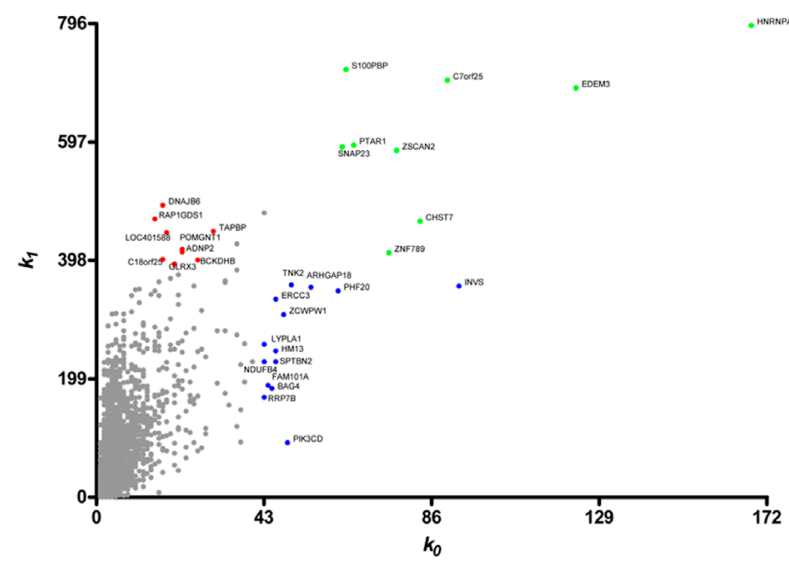

Communities having the highest node strength (total probability for their nodes to connect to distinct communities) hold the most significant functional interactions in the network [27, 30, 31]. Therefore, the subsequent analysis of gene communities in DE and CO networks was performed considering not only the gene/ node hierarchy but, and principally, the networks' CGCSs.

\section{MicroRNA target analyses}

We obtained 53 differentially expressed miRNAs: 47 down-regulated and 6 up-regulated in DS group. Six of these miRNAs were found to be abundantly expressed (a 30 times average increase) in CT and DS thymic tissue (Table S3). The interaction between these 53 differentially expressed miRNAs and the 538 DE genes (obtained through SAM) resulted in a miRNA-DE genes interaction graph containing $219 \mathrm{DE}$ genes and 53 miRNAs, summing up 455 interactions. A total of 10 miRNAs have experimentally validated gene-miRNA interactions, whereas the predicted interactions encompassed all

B

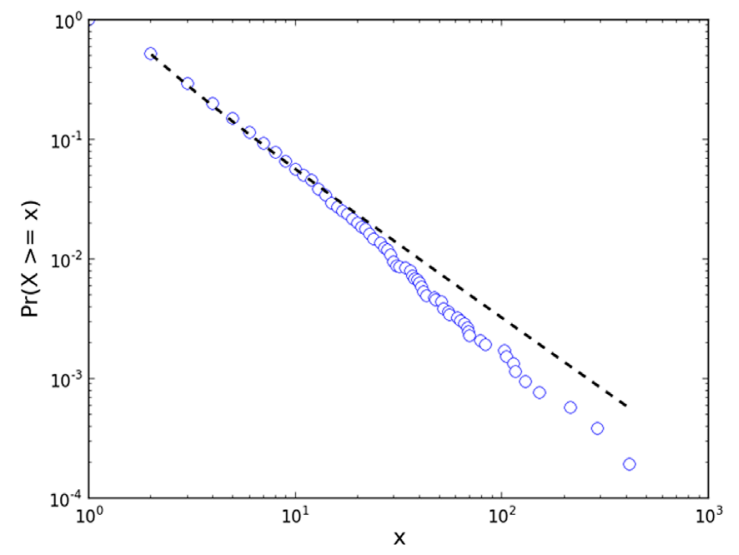

D

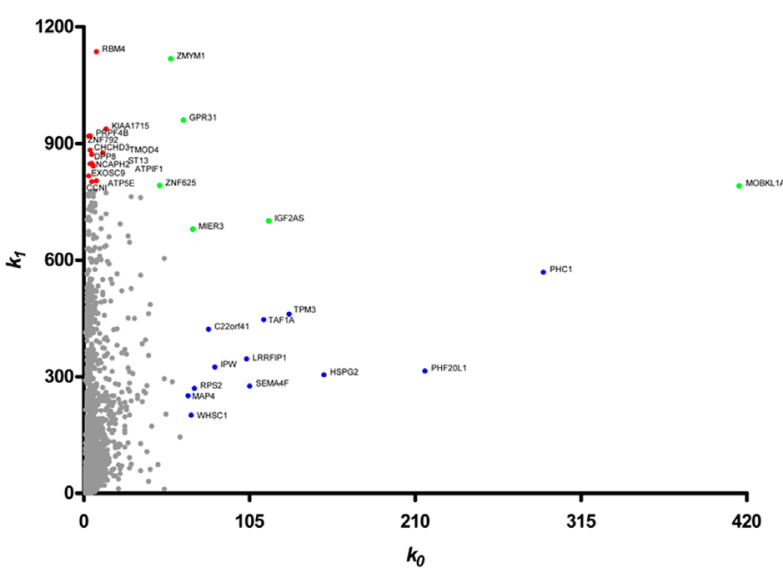

Figure 2: Node distribution and categorization for CO networks. Kolmogorov-Smirnov test for scale free status for CT-CO (A) and DS-CO (B) networks. Scatter plots of node degree (k0) vs concentric node degree (k1) measures of GO annotated genes in CT-CO (C) and DS-CO networks (D). Hubs (blue), VIPs (red) and high-hubs (green) are identified by their gene symbols. 
Table 1: Transcriptional modules (communities), HH genes, and miRNA interactions in CT-DE network

\begin{tabular}{|c|c|c|c|c|c|c|}
\hline & & & & Function in thrmm & microRNAs & \\
\hline Gene & Location & Comm $^{\mathrm{a}}$ & Category & Function in thymus & Downregulated & Upregulated \\
\hline ARHGAP1 & $11 \mathrm{p} 11.2$ & $\mathrm{~A}$ & HHUB & T-cell development & & \\
\hline BTG3 & $21 \mathrm{q} 21.1$ & $\mathrm{~A}$ & HHUB & T-cell development & miR-548d-5p & miR-548am-5p \\
\hline CASP4 & $11 \mathrm{q} 22.2-\mathrm{q} 22.3$ & $\mathrm{~A}$ & HHUB & T-cell development & & \\
\hline COG1 & $17 \mathrm{q} 25.1$ & $\mathrm{~A}$ & HHUB & Golgi/ER & & miR-550a-5p \\
\hline MGST2 & $4 q 28.3$ & A & HHUB & Stress response & & $\begin{array}{l}\mathbf{m i R}-15 \mathbf{b}-\mathbf{5 p} \\
\text { miR-497-5p }\end{array}$ \\
\hline MRPS6 & $21 \mathrm{q} 22.11$ & $\mathrm{~A}$ & HHUB & Mitochondrial process & & \\
\hline RILPL2 & $12 \mathrm{q} 24.31$ & $\mathrm{~A}$ & VIP & MHC-related & & \\
\hline RNF11 & $1 \mathrm{p} 32$ & A & HHUB & TEC-related & & $\begin{array}{l}\text { miR-129-2-3p } \\
\text { miR-550a-5p }\end{array}$ \\
\hline$S C C P D H$ & $1 \mathrm{q} 44$ & A & HHUB & Thymic homeostasis & miR-548d-5p & miR-548am-5p \\
\hline TMEM59 & $1 \mathrm{p} 32.3$ & A & HHUB & Golgi/ER & & \\
\hline$F B X L 5$ & $4 p 15.32$ & $\mathrm{~F}$ & VIP & Thymic homeostasis & & $\begin{array}{l}\text { miR-125a-5p } \\
\text { miR-125b-5p } \\
\text { miR-150-5p }\end{array}$ \\
\hline GNPDA2 & $4 \mathrm{p} 12$ & $\mathrm{~F}$ & HHUB & Thymic homeostasis & miR-548d-5p & miR-548am-5p \\
\hline$M C M 3 A P$ & $21 \mathrm{q} 22.3$ & $\mathrm{~F}$ & VIP & Cell proliferation & & \\
\hline$P I G P$ & $21 \mathrm{q} 22.2$ & $\mathrm{~F}$ & HHUB & T-cell development & & \\
\hline SETD4 & $21 \mathrm{q} 22.13$ & $\mathrm{~F}$ & VIP & Epigenetic control & & $\operatorname{miR}-324-3 p$ \\
\hline$T B C 1 D 9 B$ & $5 q 35.3$ & $\mathrm{~F}$ & VIP & Autophagy & & \\
\hline USO1 & $4 q 21.1$ & $\mathrm{~F}$ & HHUB & Golgi/ER & & $\begin{array}{l}\operatorname{miR}-197-3 p^{b} \\
\operatorname{miR}-23 b-3 p\end{array}$ \\
\hline$D G A T 1$ & $8 \mathrm{q} 24.3$ & G & HHUB & T-cell development & & \\
\hline HSPA1A & $6 \mathrm{p} 21.3$ & $\mathrm{G}$ & HHUB & Thymic microenviron. & & \\
\hline$Y I P F 2$ & $19 \mathrm{p} 13.2$ & $\mathrm{G}$ & VIP & unknown & & \\
\hline ZNHIT3 & $17 \mathrm{q} 12$ & $\mathrm{G}$ & HHUB & unknown & & \\
\hline C11orf75 & $11 \mathrm{q} 21$ & B & HHUB & unknown & & $\operatorname{miR}-23 b-3 p$ \\
\hline CEACAMI & $19 q 13.2$ & B & HUB & T-cell development & & $\begin{array}{l}\text { miR-30c-5p } \\
\text { miR-30d-5p }\end{array}$ \\
\hline IFNGR2 & 21q22.11 & B & HUB & T-cell development & & $\begin{array}{l}\text { miR-30c-5p } \\
\text { miR-30d-5p }\end{array}$ \\
\hline CD59 & $11 \mathrm{p} 13$ & $\mathrm{C}$ & HUB & T-cell development & & let-7f-1-3p \\
\hline$C G N$ & $1 q 21$ & $\mathrm{C}$ & HUB & T-cell development & & $\begin{array}{l}\text { miR-125b-5p } \\
\text { miR-766-3p } \\
\text { miR-125a-5p }\end{array}$ \\
\hline HSPA13 & 21q11 & $\mathrm{C}$ & HHUB & T-cell development & & $\begin{array}{l}\text { miR-181a-5p }^{\mathbf{b}} \\
\text { miR-200c-3p } \\
\text { miR-205-5p }\end{array}$ \\
\hline ARHGEF4 & $2 q 22$ & $\mathrm{D}$ & HHUB & T-cell development & & miR-301a-3p \\
\hline$D L G 3$ & $\mathrm{Xq} 13.1$ & D & HHUB & T-cell development & & \\
\hline MORC3 & $21 \mathrm{q} 22.13$ & $\mathrm{D}$ & HHUB & Epigenetic control & & $\begin{array}{l}\text { let-7b-3p } \\
\text { miR-200c-3p }\end{array}$ \\
\hline$A P P$ & $21 \mathrm{q} 21.3$ & E & VIP & Thymic microenviron. & & $\begin{array}{l}\text { let-7b-3p } \\
\text { let-7f-1-3p } \\
\end{array}$ \\
\hline GSTO1 & $10 \mathrm{q} 25.1$ & $\mathrm{E}$ & VIP & Stress response & & \\
\hline
\end{tabular}

${ }^{a}$ Comm: Community; ${ }^{b}$ validated miRNA-gene interaction (miRTarBase databank); ER: endoplasmic reticulum. In bold: abundantly expressed miRNAs. 
differentially expressed miRNAs. Tables 1 and 2 contain brief gene function descriptions for all $\mathrm{HH}$ genes in $\mathrm{DE}$ networks and: i) all miRNA-gene validated interactions; ii) predicted miRNA-gene interactions involving at least one $\mathrm{HH}$ gene. The gene coexpression networks for CT-DE and DS-DE groups are displayed in Figure 6 (CT-DE network) and 7 (DS-DE network). Code colors identify the distinct gene communities. Hierarchy-categorized selected nodes are identified by their corresponding GO gene symbols; node border colors indicate hubs (blue), VIPs (red) or high-hubs (green). MiRNA-gene interactions are shown for high- and low-hierarchy genes: larger vees correspond to abundantly expressed miRNAs; the blue lines indicate validated interactions whereas predicted interactions are indicated by red lines.

MiRNA interactions with CO network genes (CT$\mathrm{CO}$ and DS-CO) were investigated only for high-hierarchy genes $(\mathrm{HH})$ employing miRTarBase (experimentally validated miRNA-target gene interaction database) and mirPath (predicted miRNA-target gene interaction database). Accordingly, $\mathrm{HH}$ subnetworks were constructed for CT and DS groups. The CT-CO HH subnetwork (Figure 8A) had 39 nodes and 54 edges, whereas the DS$\mathrm{CO}$ network encompassed 44 nodes and 59 edges (Figure $8 \mathrm{~B})$. Code colors and symbols were the same described above for DE networks. In the CT-CO subnetwork, a total of 25 miRNAs were found to interact with $14 \mathrm{HH}$ genes. In the DS-CO subnetwork we identified 29 miRNAs interacting with $15 \mathrm{HH}$ genes (Figure 8B). Again, larger vees indicate abundantly expressed miRNAs, the blue lines indicate validated interactions, and predicted interactions are indicated by red lines. Tables 3 and 4 contain the description of gene functions and miRNA interactions (validated and predicted) for all $\mathrm{HH}$ genes in CO subnetworks.

\section{Gene communities and microRNA-gene interactions in CT and DS networks}

Here we summarize the biological functions of the HH genes - hubs, VIPs and high- hubs - found in each of the DE and CO networks' communities. Since these genes play an essential role in keeping network's structure and functions $[29,32,33]$, their interactions with differentially expressed miRNAs are also considered in this section. Tables 1-4 show community distribution, biological functions/products, and miRNA interactions assigned for the $\mathrm{HH}$ genes in each network.

\section{CT-DE network}

In CT-DE, communities A and F (Figure 6 and Table 1) encompass most of the $\mathrm{HH}$ genes. Interestingly, $\mathrm{A}$ and $\mathrm{F}$ harbor four genes that also appear as $\mathrm{HH}$ genes in DS-DE network. Two of these genes, FBXL5 [34, 35] and GNPDA2 [36], both in community F, have biological functions associated to the maintenance of thymic microenvironment (iron homeostasis, ROS sensing, lipid metabolism). The two other HH genes shared with DSDE network belong to community A: one is ARHGAP1, a RhoGTPase activating protein $[37,38]$, and the other is CASP4, which is involved in thymic lymphopoiesis [39, 40].

Community A encompasses ten $\mathrm{HH}$ genes and nine of these genes are high-hubs (Table 1), thus indicating their relevance for network functioning and stability [33, 41]. Interestingly, two of these high-hubs are located in DSCR, the Down Syndrome Critical Region (21q2121q22.3) of chromosome 21 (HSA21) [10]. One is BTG3, which codes for a member of the anti-proliferative BTG/ Tob protein family known as ANA or BTG3 [42]. This gene and BTG2, another BTG/Tob family member, act together in the regulation of stage-specific proliferation of developing thymocytes [43]. The other high-hub is MRPS6, a gene that encodes the mitochondrial ribosomal protein S6, a component of the oxidative phosphorylation system (OXPHOS), the main source of T-cell's energy under resting conditions [44]. OXPHOS is one of the canonical cellular pathways affected by changes in gene expression levels with thymocytes age [45]. These two genes are known to have altered expression in Down syndrome $[46,47]$. All the other genes in community A are also associated to thymic cell development/selection, or to thymic cell survival and apoptosis pathways, as described below.

ARHGAP1 (aliase RhoGAP), codes for a Rho GTPase activating protein. Rho GTPase and RhoGAP are essential for cell motility [48]. Rho GTPase has critical regulatory roles in thymus development, such as thymocyte proliferation and survival, and thymic egress $[37,38]$. Additionally, RhoGAP deletion is associated with thymic cancer [49]. CASP4 codes for caspase-4, an apoptosis-related cysteine peptidase which is also an activator of caspase-1[39]. The activation of caspase-1 decreases thymic lymphopoiesis [46]. RILPL2, the only VIP in community $\mathrm{A}$, is involved regulating lysosomal related organelles (LRO) morphology and MHCII presentation [50]. COG1 acts on Golgi-associated processing of glycoconjugates and intra-Golgi trafficking $[51,52]$. SCCPDH codes for saccharopine dehydrogenase, an enzyme involved in lysine metabolism [53] and, by extension, in thymic homeostasis [54]. RNF11gene product is the RING finger protein 11, which binds to Smad4 and enhances Smad4-dependant TGF- $\beta$ signaling [55]. TGF- $\beta$ signaling has a pivotal role in the regulation of medullary thymic epithelial cell development [56]. MGST2 (aliase GST2) codes for glutathione S-transferase 2, a molecule involved, via S-glutathionylation, in response to oxidative stress and in cell survival pathways [57, 58, 59]. And, lastly, TMEM59, a gene coding for a ubiquitously expressed Golgi-associated protein involved 
in selective autophagy [60], and also in the glycosylation, cell surface expression, and secretion of APP, the amyloid precursor protein [61]. APP is secreted by thymic stromal cells [62].

The high-hierarchy genes in community $\mathrm{F}$ comprise four VIPs and three high-hubs (Table 1), whose functions are briefly described here. One of the VIPs, FBXL5, and the high-hub GNPDA2 are related to thymic microenvironment and were already commented above. Two HH genes in this community are related to cell proliferation and apoptosis. One is $M C M 3 A P$, a VIP that codes for the MCM3 (minichromosome maintenance protein 3) binding protein. MCM3AP interacts with the germinal center-associated protein (GANP) and the glucocorticoid receptor in order to regulate cell proliferation [63]. The other is the high-hub USO1, which is involved in ER-to Golgi transport, regulating mitosis progression and apoptosis [64]. The high-hub $P I G P$ encodes the GPI (glycosylphosphatidylinositol)anchored semaphorin7A, a protein that regulates T-cell development, especially positive selection $[65,66]$.

A

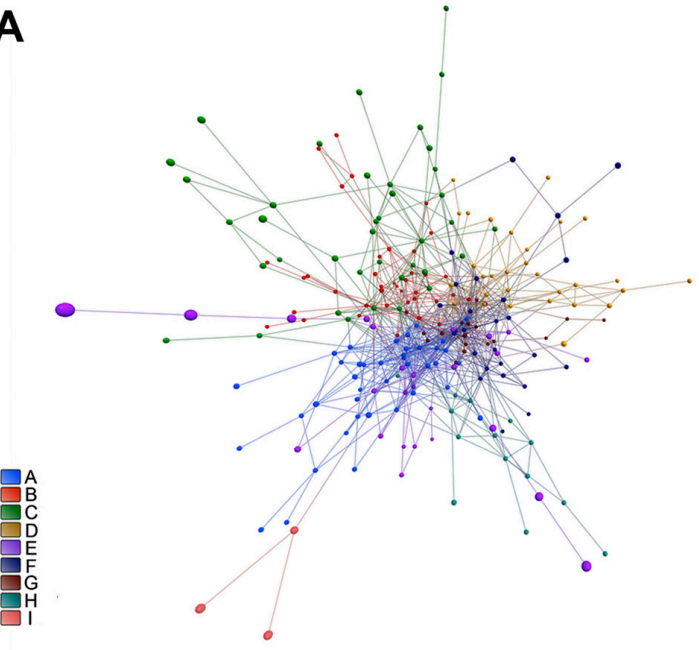

C

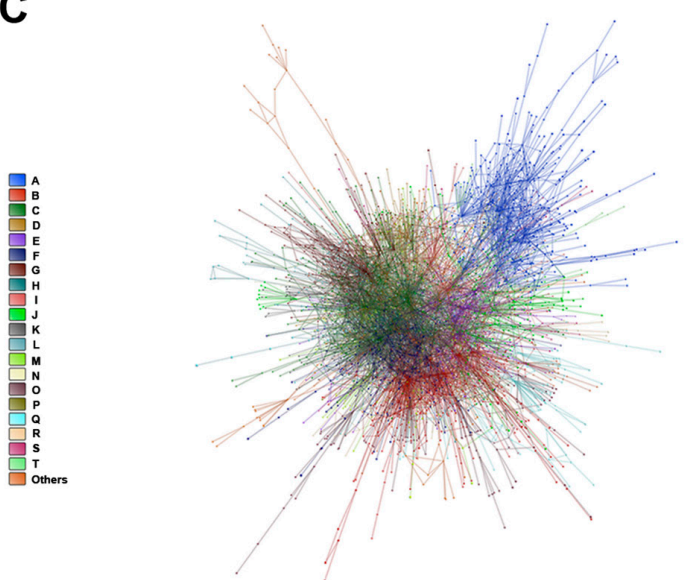

SETD4 is a VIP that codes for a cytosolic and nuclear lysine methyltransferase related to histone lysine methylation [67]. Histone methylation serves to regulate chromatin and gene expression. $T B C 1 D 9 B$ is a high-hub and codes for a Rab GTPase-activating protein involved in the regulation of endocytic and autophagy pathways [68]. Autophagy is an essential process for negative and positive thymocyte selection, for promoting Treg and iNKT cell differentiation, and for thymocyte survival as well [69, 70]. It is also noteworthy that three of these genes MCM 3AP, PIGP and SETD4 - are located in DSCR (Table 1). Moreover, $P I G P$ was found to be overexpressed in the fetal cortex brain of Down syndrome subjects [71].

Overall, most of the $\mathrm{HH}$ genes in communities $\mathrm{A}$ and $\mathrm{F}$ have relevant roles in thymus functioning and microenvironment. The very fact that five of these genes are found to be located in DSCR/HSA21 indicates that chromosome 21 dysregulation may impact thymus development and functioning. This is confirmed by the finding that three additional DSCR genes and one HSA21 (21q11) gene appear among the HH genes in the

B

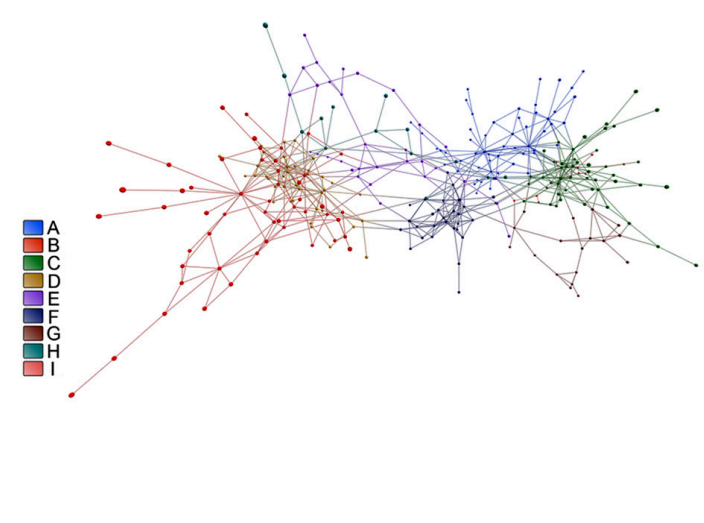

D

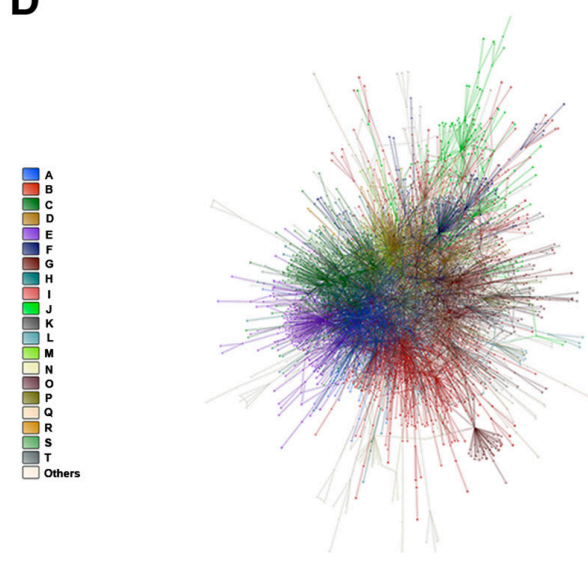

Figure 3: DE and CO networks and respective gene communities (modules). Network topology and community structure for CT-DE, DS-DE, CT-CO and DS-CO networks are depicted in A, B, C and D, respectively. Gene communities are distinguished by different colors and identified by the right side bar code. 
Table 2: Transcriptional modules (communities), HH genes, and miRNA interactions in DS-DE network

\begin{tabular}{|c|c|c|c|c|c|c|}
\hline & & & & Function in thumu & microRNAs & \\
\hline Gene & Location & Comm $^{a}$ & Category & Function in tnymus & Downregulated & Upregulated \\
\hline CASP4 & 11q22.2-q22.3 & $\mathrm{C}$ & VIP & T-cell development & & \\
\hline FBXL5 & $4 p 15.32$ & $\mathrm{C}$ & HHUB & Thymic homeostasis & $\begin{array}{l}\text { miR-125a-5p } \\
\text { miR-125b-5p } \\
\text { miR-150-5p }\end{array}$ & \\
\hline$F O X J 3$ & $1 \mathrm{p} 34.2$ & $\mathrm{C}$ & HUB & Cell cycle control & let-7f-1-3p & miR-196a-5p \\
\hline GNPDA2 & $4 \mathrm{p} 12$ & $\mathrm{C}$ & HUB & Thymic homeostasis & miR-548am-5p & miR-548d-5p \\
\hline NDUFS4 & $5 q 11.1$ & $\mathrm{C}$ & VIP & Mitochondrial process & miR-766-3p & \\
\hline NDUFV3 & $21 \mathrm{q} 22.3$ & $\mathrm{C}$ & HHUB & Mitochondrial process & & \\
\hline NFU1 & $2 \mathrm{p} 15-\mathrm{p} 13$ & $\mathrm{C}$ & VIP & Mitochondrial process & $\operatorname{miR}-625-5 p$ & \\
\hline PGRMC1 & $\mathrm{Xq} 22-\mathrm{q} 24$ & $\mathrm{C}$ & HHUB & T-cell development & miR-486-5p & \\
\hline PTPN12 & $7 q 11.23$ & $\mathrm{C}$ & HHUB & T-cell development & $\begin{array}{l}\text { miR-149-5p } \\
\text { miR-200c-3p }\end{array}$ & \\
\hline TRIM39 & $6 \mathrm{p} 21.3$ & $\mathrm{C}$ & VIP & Cell cycle control & miR-140-3p & \\
\hline ATP6AP1 & $\mathrm{Xq} 28$ & $\mathrm{~A}$ & HHUB & Autophagy & & miR-449a \\
\hline C5orf32 & $5 q 31.3$ & $\mathrm{~A}$ & VIP & Stress response & & \\
\hline CYB5R1 & $1 \mathrm{q} 32.1$ & $\mathrm{~A}$ & VIP & Stress response & & \\
\hline HOMER2 & $15 q 24.3$ & A & HUB & T-cell development & $\begin{array}{l}\text { let-7b-3p } \\
\text { let-7f-1-3p } \\
\text { miR-548am-5p }\end{array}$ & $\operatorname{miR}-548 d-5 p$ \\
\hline MORN4 & $10 \mathrm{q} 24.2$ & A & HHUB & Thymic homeostasis & miR-205-5p & \\
\hline$M P S T$ & $22 q 13.1$ & $\mathrm{~A}$ & VIP & Thymic homeostasis & miR-193b-3p $p^{b}$ & \\
\hline PPP1R14C & $6 \mathrm{q} 24.3-\mathrm{q} 25.3$ & A & HHUB & Cell cycle control & $\begin{array}{l}\text { miR-30c-5p } \\
\text { miR-30d-5p }\end{array}$ & \\
\hline PTRH1 & $9 \mathrm{q} 34.11$ & $\mathrm{~A}$ & HHUB & Thymic microenviron. & & \\
\hline PTTG1IP & $21 \mathrm{q} 22.3$ & $\mathrm{~A}$ & VIP & TEC-related & & \\
\hline$D O K 7$ & $4 \mathrm{p} 16.3$ & $\mathrm{D}$ & HUB & T-cell development & & \\
\hline MFSD4 & $1 \mathrm{q} 32.1$ & $\mathrm{D}$ & HUB & Thymic homeostasis & let- $7 b-3 p$ & \\
\hline NFE2 & $12 q 13$ & $\mathrm{D}$ & HHUB & T-cell development & & \\
\hline$P 2 R Y 2$ & 11q13.5-q14.1 & $\mathrm{D}$ & HUB & TEC-related & miR-193b-3p & \\
\hline$S A A 2$ & 11p15.1-p14 & $\mathrm{D}$ & VIP & unknown & & \\
\hline$T M E M 45 A$ & $3 q 12.2$ & $\mathrm{D}$ & HUB & Hassall's corp. related & miR-181a-5p ${ }^{b}$ & \\
\hline$A N X A 9$ & $1 \mathrm{q} 21$ & B & HHUB & Thymic microenviron. & & \\
\hline C17orf58 & $17 q 24.2$ & $\mathrm{~B}$ & VIP & Thymic microenviron. & $\operatorname{miR}-200 b-5 p$ & \\
\hline NLRP12 & $19 q 13.42$ & B & HUB & unknown & & \\
\hline$P I P$ & $7 \mathrm{q} 34$ & B & HUB & Thymic microenviron. & & \\
\hline ANKS6 & $9 q 22.33$ & $\mathrm{~F}$ & HUB & unknown & $\begin{array}{l}\text { miR-125a-5p } \\
\text { miR-125b-5p }\end{array}$ & \\
\hline ARHGAP1 & $11 \mathrm{p} 11.2$ & $\mathrm{~F}$ & HUB & T-cell development & & \\
\hline C11orf24 & $11 \mathrm{q} 13$ & $\mathrm{~F}$ & HUB & Golgi/ER & $\operatorname{miR}-193 b-3 p^{b}$ & \\
\hline$L A P T M 4 B$ & $8 \mathrm{q} 22.1$ & $\mathrm{~F}$ & HHUB & Autophagy & $\operatorname{miR}-625-5 p$ & \\
\hline CYFIP1 & $15 q 11$ & $\mathrm{H}$ & VIP & Golgi/ER & $\operatorname{miR} 497-5 p$ & \\
\hline
\end{tabular}

${ }^{a}$ Comm: Community; ${ }^{b}$ validated miRNA-gene interaction (miRTarBase databank); ER: endoplasmic reticulum. In bold: abundantly expressed miRNAs. 
other CT-DE communities (Table 1), as described below. Community $\mathrm{F}$ has the highest connection weight in CT-DE network and community $\mathrm{A}$ has the third one (Figure 5A).

Community $\mathrm{C}$ harbor only three $\mathrm{HH}$ genes: two of them, CD59 and CGN, are hubs. CD59 codes for a complement regulatory protein located on Hassall's corpuscles and medullary epithelial cells [72]. CD59 is putatively involved in the thymic selection of $\mathrm{T}$ regulatory cells $[72,73]$. $C G N$ codes for cingulin, a tight junction protein present in Hassal's corpuscles [74]. Cingulin regulates RhoA signaling [75], which has an essential role in thymocyte development [76]. The third $\mathrm{HH}$ gene in community $\mathrm{C}$ is the high-hub HSPA13 (located on 21q11) which codes for the heat shock protein family member 13, known as SCTH. One of the SCTH functions is to sensitize cells to tumor necrosis factor-related apoptosisinducing ligand (TRAIL)-induced apoptosis [77]. TRAIL is a mechanism underlying thymic negative selection [78]. Therefore, all these three genes act on thymus medullar area.

Community $\mathrm{B}$ has three $\mathrm{HH}$ genes. Two of these genes - CEACAM1 and IFNGR2 - are hubs and exert known functions in thymus. CEACAM1 encodes a type I-transmembrane glycoprotein which is a coinhibitory receptor for TCR-CD3 complex signaling [79]. IFNGR2 codes for the IFN- $\gamma$ receptor 2 , a molecule involved in the migration of mature thymocytes [80]. This gene is located in the DSCR (21q22.11). The third gene is C11orf75 (aliase SMCO4), a high-hub coding for the single-pass membrane protein (HGNC 24810) with coiled domains 4, whose functions in thymus are yet unknown.

Community D has three high-hubs. MORC3 codes for a highly conserved nuclear protein that is an epigenetic regulator associated with senescence and p53 regulation $[81,82]$. This gene is located in the DSCR (21q22.13). ARHGEF4 codes for Asef, a guanine-nucleotide exchange factor (GEF) which is specific for Cdc42 [83], a Rho GTPase critically involved in thymopoiesis [84]. Finally,
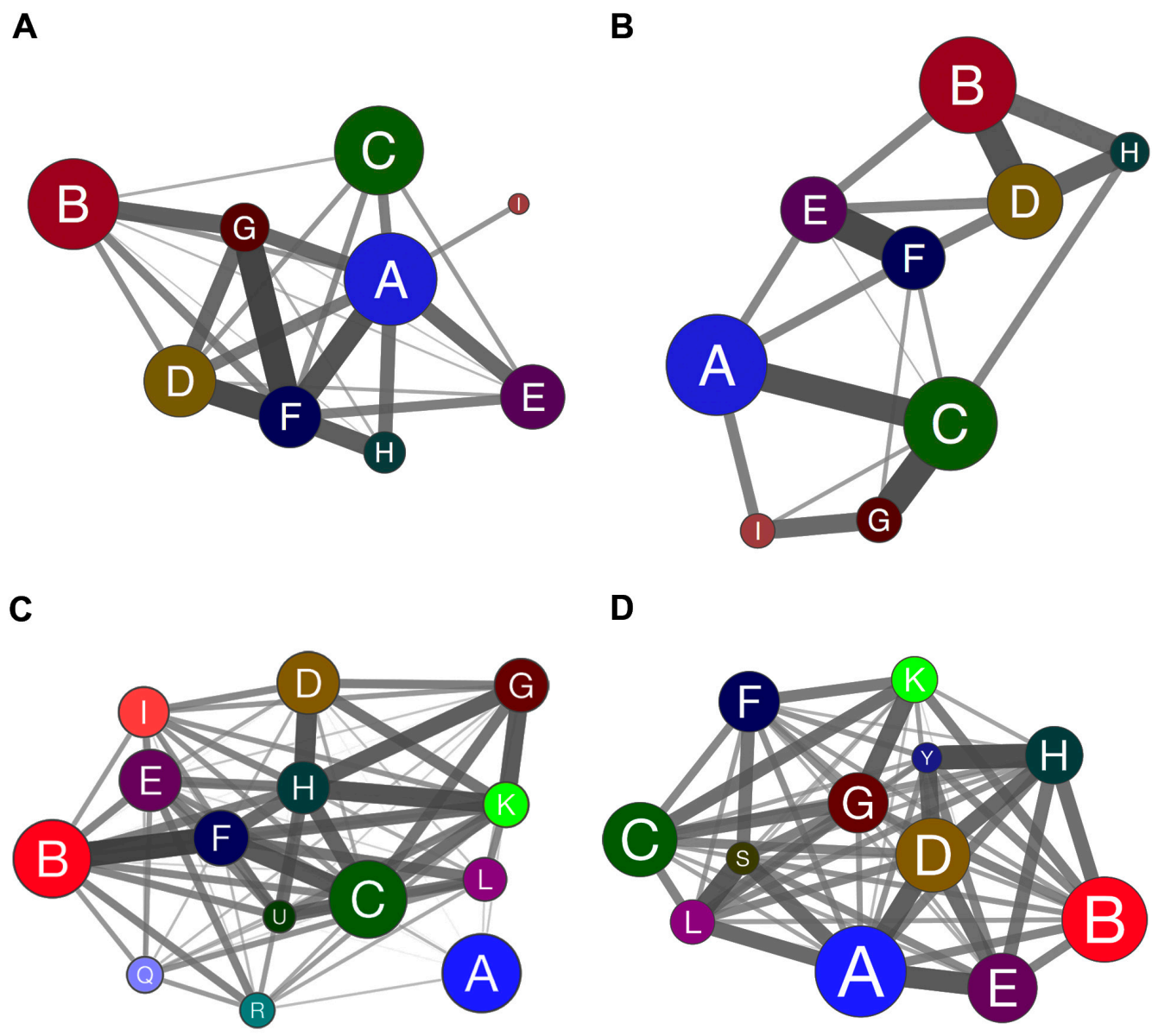

D

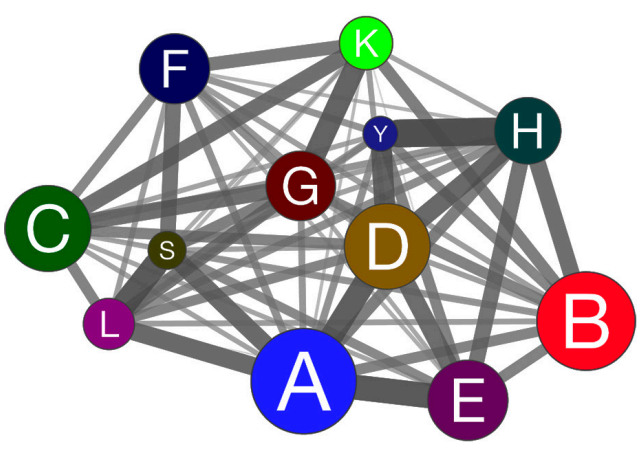

Figure 4: Coarse-grained community structure (CGCS) diagrams showing the relationships among gene communities obtained for DE and CO networks. CGCSs are depicted for all communities of CT-DE (A) and DS-DE (B) networks. CGCSs CT$\mathrm{CO}(\mathbf{C})$ and DS-CO (D) networks are restricted to communities harboring at least one high-hierarchy gene. The communities, identified by different colors in each CGCS diagram, are collapsed in a single node and edges connect all the communities weighted by the fraction of edges existing against all possible edges between two communities. The edge width and intensity is proportional to the connection weight of edges linking distinct communities. The node size is proportional to the number of nodes in each community. 
there is $D L G 3$, a gene coding for a membrane-associated guanylate kinase (MAGUK) [85] which recruits Nedd-4 ubiquitin ligases involved in key aspects of TCR signaling and T-cell functioning [86]. This community has the fourth highest connection weight value among the eight CT-DE communities harboring $\mathrm{HH}$ genes.

Community $\mathrm{E}$ has only two $\mathrm{HH}$ genes and both are VIPs. APP (located in DSCR, 21q21.3) codes for the amyloid precursor protein, a hallmark of Down syndrome [87], whose overexpression severely affects thymic functions. GSTO1 codes for a glutathione S-transferase involved in oxidative stress response and detoxification processes $[58,88]$.

Community $\mathrm{G}$ is the only CT-DE community with no $\mathrm{HH}$ genes in HSA21. This community has four $\mathrm{HH}$ genes, whose functions are summarized here. DGAT1 is a high-hub involved in diacylglycerol metabolism (DAG). DAG attenuates T-cell receptor signaling and ensures T-cell passage along check-points during thymocyte differentiation [89]. HSPA1A, also a high-hub, codes for a HSP70 chaperone that accelerates protein translocation and the unfolding of stable protein aggregates [90,91]. YIPF2, a VIP, codes for a member of the Yip1 family of proteins. Proteins of this family are mostly involved in ER-to Golgi membrane transport, but the specific function of human YIPF2 is still unkown [92]. The remaining $\mathrm{HH}$ gene in this community is the high-hub ZNHIT3, which codes for a C/D small nucleolar ribonucleoprotein assembly factor [93], hitherto without a defined function in thymus. Community $\mathrm{G}$ has the second highest connection weight value in CT-DE network (Figure 5A).

An overview of CT-DE communities (Table 1) shows that many $\mathrm{HH}$ genes are related to relevant thymic functions, thus reflecting the correlation between transcriptional modules, or network communities, with thymic functional areas. For instance: community $\mathrm{C}$ is related to Hassall's corpuscle and medullar area; communities A and $\mathrm{F}$ are principally related to thymocyte development and thymic microenvironment; communities $\mathrm{B}$ and $\mathrm{D}$ are linked to thymocyte development. Moreover, the communities with highest connection values harbor most of the $\mathrm{HH}$ genes related to relevant thymic processes, chiefly linked to thymic pathways and thymus microenvironment. The correspondence between transcriptional and functional modules in biological systems has been found in other genomic studies of immunological processes using whole tissues [revised in 27].
A

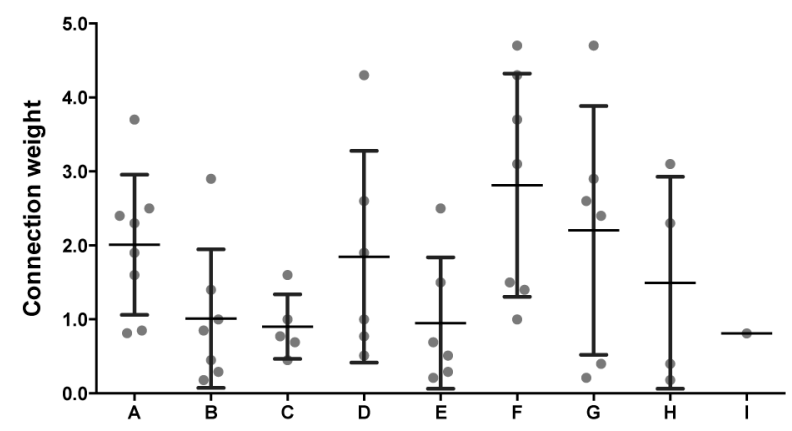

C

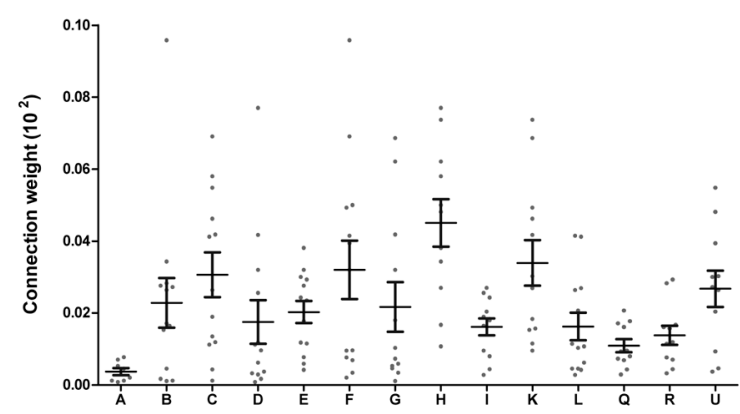

\section{B}

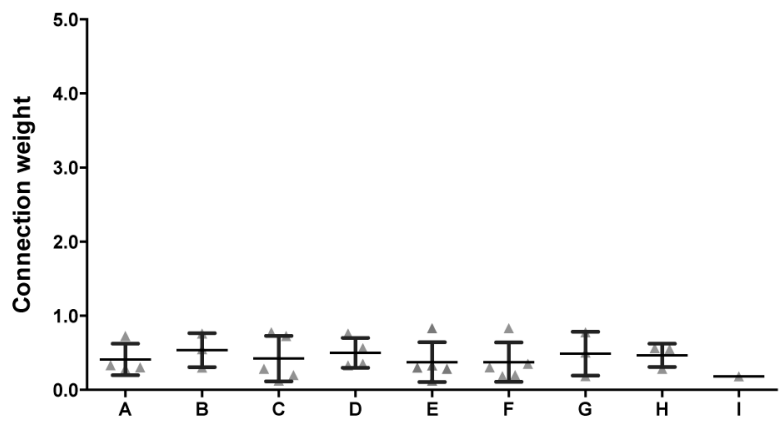

\section{D}

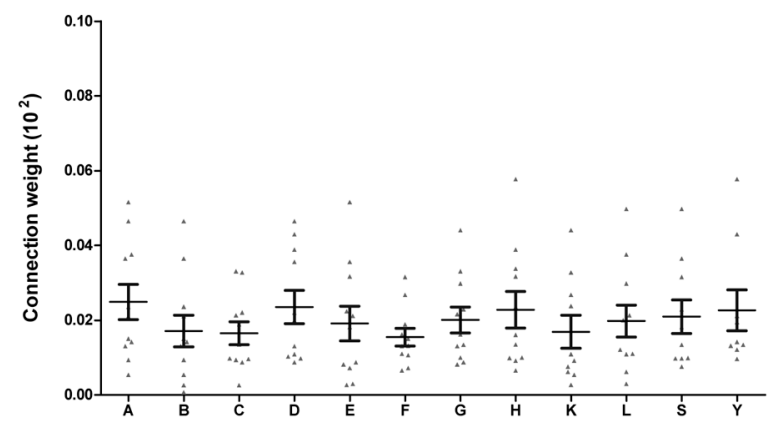

Figure 5: Connection weight values. Connection weight values were obtained for all the constituent communities of CT-DE (A) and DS-DE (B) networks, and for the CO communities harboring at least one high-hierarchy gene, here depicted in (C) for CT-CO and in (D) for DS-CO. Dots represent the connection weights of the links centered in each community. 
Table 3: Transcriptional modules (communities), HH genes, and miRNA interactions in CT-CO network

\begin{tabular}{|c|c|c|c|c|c|c|}
\hline & & & & 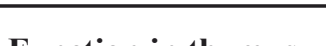 & microRNAs & \\
\hline Gene & Location & Comm $^{\mathrm{a}}$ & Category & Function in thymus & Downregulated & Upregulated \\
\hline$A D N P 2$ & $18 \mathrm{q} 23$ & B & VIP & Cell development & & $\begin{array}{l}\text { miR-15b-5p } \\
\text { miR-497-5p }\end{array}$ \\
\hline C18orf25 & $18 \mathrm{q} 21.1$ & $\mathrm{~B}$ & VIP & Cell development & miR-548d-5p & miR-766-3p \\
\hline$E R C C 3$ & $2 q 21$ & $\mathrm{~B}$ & HUB & Cell development & & \\
\hline HNRNPAO & $5 q 31$ & $\mathrm{~B}$ & HHUB & Transcription control & & \\
\hline$S N A P 23$ & $15 q 14$ & $\mathrm{~B}$ & HHUB & Cell development & & \\
\hline$T A P B P$ & $6 \mathrm{p} 21.3$ & $\mathrm{~B}$ & VIP & MHC-related & & \\
\hline$T N K 2$ & $3 q 29$ & B & HUB & TEC-related & & $\begin{array}{l}\text { miR-149-5p } \\
\text { miR-205-5p } \\
\text { miR-484 }\end{array}$ \\
\hline ZSCAN2 & $15 q 25.2$ & B & HHUB & Transcription control & & \\
\hline EDEM3 & $1 \mathrm{q} 25$ & $\mathrm{C}$ & HHUB & MHC-related & & $\begin{array}{l}\text { miR-30c-5p } \\
\text { miR-30d-5p } \\
\text { miR-200c-3p }\end{array}$ \\
\hline LOC401588 & Xp11.23 & $\mathrm{C}$ & VIP & Epigenetic control & & \\
\hline$R A P 1 G D S 1$ & $4 q 23-q 25$ & $\mathrm{C}$ & VIP & T-cell development & miR-449a & miR-29a-3p \\
\hline$S 100 P B P$ & $1 \mathrm{p} 35.1$ & $\mathrm{C}$ & HHUB & Cell migration & & $\begin{array}{l}\operatorname{miR}-23 b-3 p \\
\text { miR-30c-5p } \\
\text { miR-30d-5p } \\
\text { miR-200c-3p } \\
\text { miR-361-3p } \\
\text { miR-455-3p } \\
\text { miR-484 }\end{array}$ \\
\hline$B C K D H B$ & $6 q 14.1$ & $\mathrm{~F}$ & VIP & Mitochondrial process & & \\
\hline$G L R X 3$ & $10 q 26$ & $\mathrm{~F}$ & VIP & T-cell development & & \\
\hline PHF20 & $20 q 11.22-q 11.23$ & $\mathrm{~F}$ & HUB & T-cell development & & $\begin{array}{l}\text { miR-197-3p }{ }^{b} \\
\text { miR-15b-5p } \\
\text { miR-30c-5p } \\
\text { miR-30d-5p } \\
\text { miR-125a-5p } \\
\text { miR-125b-5p } \\
\text { miR-145-5p } \\
\text { miR-301a-3p } \\
\text { miR-497-5p }\end{array}$ \\
\hline FAM101A & $12 \mathrm{q} 24.31$ & $\mathrm{~A}$ & HUB & unknown & & \\
\hline SPTBN2 & $11 \mathrm{q} 13$ & A & HUB & Golgi/ER & & $\begin{array}{l}\text { miR-15b-5p } \\
\text { miR-361-3p } \\
\text { miR-497-5p }\end{array}$ \\
\hline ARHGAP18 & $6 q 22.33$ & $\mathrm{D}$ & HUB & T-cell development & & \\
\hline NDUFB4 & $3 q 13.33$ & $\mathrm{D}$ & HUB & Mitochondrial process & & \\
\hline$B A G 4$ & $8 \mathrm{p} 11.23$ & E & HUB & T-cell development & & $\begin{array}{l}\text { miR-15b-5p } \\
\text { miR-125a-5p } \\
\text { miR-125b-5p } \\
\text { miR-181a-5p } \\
\text { miR-497-5p } \\
\text { miR-766-3p }\end{array}$ \\
\hline CHST7 & Xp11.23 & $\mathrm{E}$ & HHUB & Thymic microenviron. & & miR-23b-3p \\
\hline DNAJB6 & $7 \mathrm{q} 36.3$ & $\mathrm{H}$ & VIP & T-cell development & & \\
\hline LYPLA1 & $8 \mathrm{q} 11.23$ & $\mathrm{H}$ & HUB & T-cell development & & $\begin{array}{l}\text { miR-23b-3p } \\
\text { miR-29a-3p }\end{array}$ \\
\hline$Z C W P W 1$ & $7 q 22.1$ & $\mathrm{I}$ & HUB & Epigenetic control & & \\
\hline ZNF789 & $7 q 22.1$ & $\mathrm{I}$ & HHUB & Transcription control & & \\
\hline C7orf25 & $7 \mathrm{p} 14.1$ & $\mathrm{~K}$ & HHUB & Mitochondrial process & & \\
\hline POMGNT1 & $1 \mathrm{p} 34.1$ & $\mathrm{~K}$ & VIP & T-cell development & & \\
\hline$I N V S$ & $9 q 31$ & G & HUB & unknown & & \\
\hline
\end{tabular}




\begin{tabular}{|l|l|l|l|l|l|l|}
\hline HM13 & $20 \mathrm{q} 11.21$ & $\mathrm{~L}$ & HUB & MHC-related & & $\begin{array}{l}\text { miR-149-5p } \\
\text { miR-296-5p } \\
\text { miR-455-3p } \\
\text { miR-625-5p }\end{array}$ \\
\hline PIK3CD & $1 \mathrm{p} 36.2$ & $\mathrm{Q}$ & HUB & Antiapoptosis & $\begin{array}{l}\text { miR-30c-5p } \\
\text { miR-30d-5p } \\
\text { miR-125a-5p } \\
\text { miR-125b-5p } \\
\text { miR-484 }\end{array}$ \\
\hline RRP7B & $22 \mathrm{q} 13.2$ & $\mathrm{R}$ & HUB & unknown & & \\
\hline PTAR1 & $9 \mathrm{q} 21.12$ & $\mathrm{U}$ & HHUB & T-cell development & $\begin{array}{l}\text { miR-23b-3p } \\
\text { miR-125a-5p } \\
\text { miR-125b-5p } \\
\text { miR-129-2-3p }\end{array}$ \\
\hline
\end{tabular}

${ }^{a}$ Comm: Community; ${ }^{b}$ validated miRNA-gene interaction (miRTarBase databank); ER: endoplasmic reticulum. In bold: abundantly expressed miRNAs.

\section{MicroRNA target interactions in CT-DE}

In CT-DE network the communities $\mathrm{A}, \mathrm{F}$, and $\mathrm{C}$ concentrate most of the interactions between $\mathrm{HH}$ genes and differentially expressed miRNA interactions. Most importantly, four genes in these communities are the only ones in the network to have interactions with differentially expressed miRNAs that are abundantly expressed in thymic tissue (Table 1, Figure 6). It is widely accepted that miRNAs give robustness to biological processes by buffering fluctuations in gene expression and/or attenuating aberrant transcripts [94]. Most of the genes in those three communities fulfill important tasks for thymic functioning, such as the ones in community C, which are related to Hassall's corspuscle and thymic medullar area. Three out of the six abundantly expressed miRNAs interacting with CT-DE network genes are found in this community - two of them exclusively. Additionally, the two genes interacting with abundantly expressed miRNAs in communities A and F, namely MGST2 and FBXL5 have important roles in maintaining thymic homeostasis. FBXL5 is also a high-hub in DS-CT network, where it interacts with the same abundantly expressed miRNAs, miR-125-5p (a HSA21-derived miRNA) and miR-150-5p. Interestingly, community A harbors all the interactions involving the miR-548 family, which is one of largest miRNA families in human genome and some of its members may form miRNA-miRNA duplexes [95]. Finally, it is also noteworthy that in CT-DE communities most of the miRNA-gene interactions occur with highhubs, the gene category that contributes most to the network robustness [33, 24].

\section{DS-DE network}

The DS-DE communities (Figure 7 and Table 2) depict thymus functioning under Down syndrome genomic dysregulation. Yet, only two out of $34 \mathrm{HH}$ genes in DS-DE network locate on DSCR in HSA21: PTTG11P
[96] and $N D U F V 3$, in communities A and C, respectively. NDUFV3, which codes for a NHDH-ubiquinone oxidoreductase complex subunit, is overexpressed in Down syndrome and contributes to DS phenotype [97, 98, 99]. However, three other genes in this network - CYB5RI [100] and ATP6AP1 [101] in community A and NFE2 [102] in community D - are well known DS biomarkers with increased expression in DS subjects [103, 104, 105], although not located on HSA21. In DS-DE network most of the $\mathrm{HH}$ genes are concentrated in communities $\mathrm{A}$ and C (Table 2).

In community $\mathrm{A}$, three out of its nine genes are related to processes involving thymic epithelial cells and thymocyte development, as follows. ATP6AP1, a high-hub, is involved in macroautophagy [106]. Macroautophagy substrates are loaded onto MHC class II of medullary thymic epithelial cells for central tolerance [101]. HOMER2, a hub, codes for member of the Homer family of scaffolding proteins which is involved, via NFAT (nuclear factor of activated T-cell) and calcineurin interactions, in thymocyte development [107, 108]. PTTG1IP, a VIP, codes for the pituitary tumor-transforming 1 (PTTG1) interacting protein and its coexpression with PTTG1 leads to the transcriptional activation of basic fibroblast growth factor, an inducer of thymic epithelial cell differentiation [96].

The other six genes in community A are mostly related to stress tolerance and cell survival. Three of these genes are VIPs: C5orf32 that encodes a cysteinerich transmembrane module with a role in stress tolerance across eukaryotes [109]; CYB5R1, which codes for the cytochrome b5 reductase, is overexpressed in DS and its increased expression is associated with higher oxidative stress [100]; and MPST, which codes for mercaptopyruvate sulfurtransferase, an antioxidant protein [110]. The three high-hubs are: PTRH1, coding for a peptidyl RNA hidrolase involved in the rapid clearing of peptidyl-t-RNA, thus preventing cell death [111]; PPPIR14C, that codes for a protein phosphatase involved cell cycle and metabolism control [112]; and MORN4 that 
codes for a MORN-repeat containing protein regulating $\mathrm{Ca} 2+$ homeostasis $[113,114]$.

In community $\mathrm{C}$, five out of the ten $\mathrm{HH}$ genes are related to thymic homeostasis, as follows. The high-hub FBXL5 and the VIP GNPDA2 - also HH genes in CT-DE network (Table 1) - are associated, respectively, to iron homeostasis [34] and ROS sensing [40], and to lipid and glucose metabolism [36]. The VIPs NDUFS4 [115] and NFU1 [116], as well as the high-hub NDUFV3, a DS biomarker [99], are members of mitochondrial respiratory chain complex I. The other five genes are mostly linked to thymocyte development and cell proliferation control. $C A S P 4$, a VIP, is a negative regulator of thymopoiesis $[39,36]$ also present in CT-DE (Table 1). FOXJ3, a hub, codes for a forkhead transcriprion factor and acts on cell cycle control [117]. PTPN12 is a high-hub and codes for a tyrosine phosphase that acts as a regulator of T-cell antigen receptor function during thymocyte development [118].
TRIM39, a VIP, codes for the RING finger protein 39 (RNF23) and is an antiapoptotic gene [119]. Finally, there is PGRMC1, a high-hub, that encodes the progesterone receptor membrane component 1 , an adaptor protein for steroid receptors [120], which may be involved in thymic output regulation [121].

Each of the other communities in DS-DE network can be associated to a particular set of functions or processes in the DS thymus. Accordingly, in community $\mathrm{D}$, most of the $\mathrm{HH}$ genes are related to thymocyte differentiation and/or to thymic medullar area. This community includes one high-hub, one VIP and four hubs. NFE2 is the high-hub and codes for the transcription factor nuclear factor erythroid 2 (NF-E2). This gene is overexpressed in DS [105] and NF-E2 may act, via DNase I hypersensitive site HS5 [122], in the induction phase of IL-4 expression in thymic CD4 T-cells [102]. $S A A 2$ is the VIP and codes for the acute phase protein

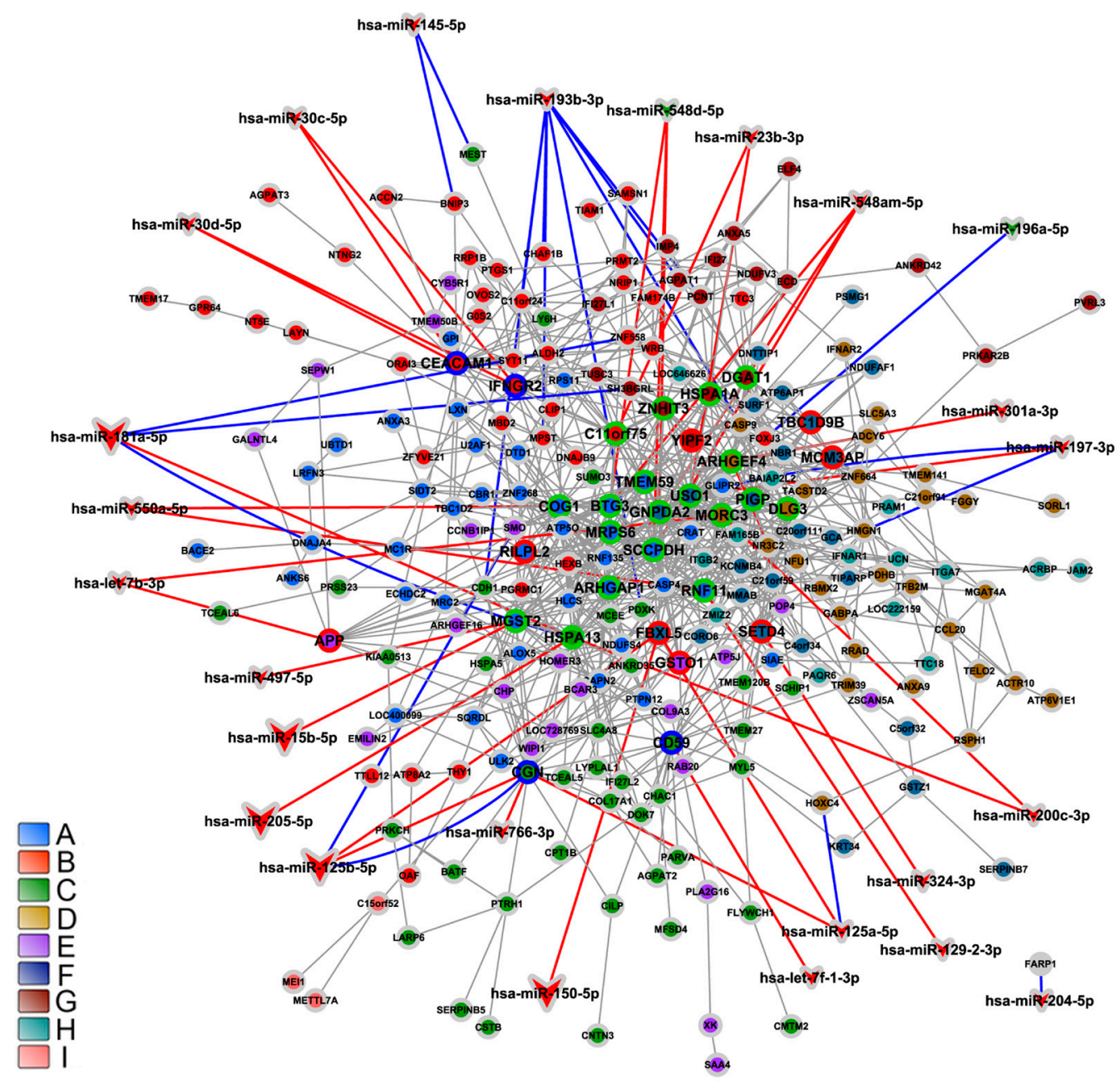

Figure 6: Integrative network analysis for CT-DE network. CT-DE network modular transcriptional repertoire structure (communities) is depicted together with all miRNA-gene validated interactions (blue lines) and the predicted miRNA-gene interactions involving at least one $\mathrm{HH}$ gene (red lines). Communities are distinguished by nodes with different filled colors. Circle or vee nodes represent respectively genes or miRNA. The circles with green, blue or red border indicate respectively high-hubs, hubs or VIPs. The vees filled with red or green colors indicate respectively miRNA hyper- or hipo-expressed. Larger vees indicate abundantly expressed miRNAs. Gene-gene links are indicated by gray lines. Gene node size is proportional to node degree $\left(k_{0}\right)$. 
Table 4: Transcriptional modules (communities), HH genes, and miRNA interactions in DS-CO network

\begin{tabular}{|c|c|c|c|c|c|c|}
\hline & & & & & microRNAs & \\
\hline Gene & Location & Comm $^{\mathrm{a}}$ & Category & Function in thymus & Downregulated & Upregulated \\
\hline ATP5E & $20 \mathrm{q} 13.32$ & $\mathrm{~A}$ & VIP & Mitochondrial process & & \\
\hline CCNI & $4 q 21.1$ & A & VIP & T-cell development & miR-149-5p & \\
\hline $\mathrm{CHCHD3}$ & $7 q 33$ & A & VIP & Mitochondrial process & & \\
\hline GPR31 & $6 q 27$ & A & HHUB & T-cell development & & \\
\hline KIAA1715 & $2 q 31$ & A & VIP & Golgi/ER & $\begin{array}{l}\text { miR-30c-5p } \\
\text { miR-30d-5p } \\
\text { miR-145-5p } \\
\text { miR-181a-5p } \\
\text { miR-550a-5p }\end{array}$ & \\
\hline MIER3 & $5 q 11.2$ & A & HHUB & Epigenetic control & $\begin{array}{l}\text { miR-331-3p } \\
\text { miR-29a-3p } \\
\text { miR-30c-5p } \\
\text { miR-30d-5p } \\
\text { miR-145-5p } \\
\text { miR-181a-5p } \\
\text { miR-200c-3p } \\
\text { miR-205-5p } \\
\text { miR-301a-3p }\end{array}$ & miR-548d-5p \\
\hline MOBKL1A & $4 q 13.3$ & A & HHUB & Cell migration & $\begin{array}{l}\mathbf{m i R}-181 \mathbf{a}-5 \mathbf{p}^{\mathbf{b}} \\
\operatorname{miR}-23 b-3 p \\
\operatorname{miR}-29 a-3 p\end{array}$ & \\
\hline NCAPH2 & $22 q 13.33$ & $\mathrm{~A}$ & VIP & T-cell development & miR-193b-3p ${ }^{b}$ & \\
\hline TMOD4 & $1 q 12$ & $\mathrm{~A}$ & VIP & Thymic demise & & \\
\hline ZMYM1 & $1 \mathrm{p} 34.3$ & $\mathrm{~A}$ & HHUB & Transcription control & & \\
\hline ZNF625 & $19 \mathrm{p} 13.2$ & $\mathrm{~A}$ & HHUB & Transcription control & & \\
\hline ATPIF1 & $1 \mathrm{p} 35.3$ & $\mathrm{C}$ & VIP & T-cell development & & \\
\hline EXOSC9 & $4 q 27$ & $\mathrm{C}$ & VIP & Transcription control & & \\
\hline LRRFIPI & $2 q 37.3$ & $\mathrm{C}$ & HUB & Transcription control & miR-181a-5p & \\
\hline$R B M 4$ & $11 \mathrm{q} 13$ & $\mathrm{C}$ & VIP & Epigenetic control & miR-197-3p $p^{b}$ & \\
\hline TAF1A & $1 q 42$ & $\mathrm{C}$ & HUB & Transcription control & & \\
\hline TPM3 & $1 \mathrm{q} 21.2$ & $\mathrm{C}$ & HUB & Cell migration & $\begin{array}{l}\text { miR-145-5p } \\
\text { miR-23b-3p } \\
\text { miR-150-5p } \\
\text { miR-204-5p } \\
\text { miR-324-3p } \\
\text { miR-766-3p }\end{array}$ & \\
\hline PHF 20L1 & $8 \mathrm{q} 24.22$ & $\mathrm{D}$ & HUB & Epigenetic control & $\begin{array}{l}\text { miR-23b-3p } \\
\text { miR-129-2-3p }\end{array}$ & miR-196a-5p \\
\hline$S E M A 4 F$ & $2 \mathrm{p} 13.1$ & $\mathrm{D}$ & HUB & Cell migration & $\begin{array}{l}\text { miR-125a-5p } \\
\text { miR-125b-5p } \\
\text { miR-181a-5p }\end{array}$ & $\operatorname{miR}-449 a$ \\
\hline ZNF792 & $19 q 13.11$ & $\mathrm{D}$ & VIP & Transcription control & $\begin{array}{l}\text { miR-125a-5p } \\
\text { miR-125b-5p }\end{array}$ & \\
\hline$D P P 8$ & $15 q 22$ & $E$ & VIP & Thymic demise & & \\
\hline PHCl & $12 \mathrm{p} 13$ & E & HUB & Epigenetic control & $\begin{array}{l}\text { miR-29a-3p } \\
\text { miR-149-5p }\end{array}$ & \\
\hline WHSC1 & $4 p 16.3$ & E & HUB & Epigenetic control & $\begin{array}{l}\text { miR-193b-3p }{ }^{b} \\
\text { miR-23b-3p } \\
\text { miR-181a-5p } \\
\text { miR-205-5p } \\
\text { miR-455-3p } \\
\text { miR-484 } \\
\text { miR-766-3p }\end{array}$ & \\
\hline$I G F 2 A S$ & $11 \mathrm{p} 15.5$ & $\mathrm{~B}$ & HHUB & Epigenetic control & & \\
\hline
\end{tabular}




\begin{tabular}{|l|l|l|l|l|l|l|}
\hline HSPG2 & $1 \mathrm{p} 36.1-\mathrm{p} 34$ & $\mathrm{~F}$ & HUB & Thymic microenviron. & $\begin{array}{l}\text { miR-15b-5p } \\
\text { miR-29a-3p } \\
\text { miR-140-3p } \\
\text { miR-455-3p } \\
\text { miR-484 } \\
\text { miR-497-5p }\end{array}$ & \\
\hline RPS2 & $16 \mathrm{p} 13.3$ & $\mathrm{G}$ & HUB & unknown & & \\
\hline PRPF4B & $6 \mathrm{p} 25.2$ & $\mathrm{H}$ & VIP & T-cell development & $\begin{array}{l}\text { miR-23b-3p } \\
\text { miR-484 }\end{array}$ & \\
\hline MAP4 & $3 \mathrm{p} 21$ & $\mathrm{~K}$ & HUB & T-cell development & $\begin{array}{l}\text { miR-15b-5p } \\
\text { miR-23b-3p } \\
\text { miR-1267 } \\
\text { miR-301a-3p } \\
\text { miR-497-5p } \\
\text { miR-766-3p }\end{array}$ & \\
\hline IPW & $15 \mathrm{q} 11.2$ & $\mathrm{~L}$ & HUB & Epigenetic control & & \\
\hline$C 220 r f 41$ & $22 \mathrm{q} 13.33$ & $\mathrm{~S}$ & HUB & unknown & & \\
\hline ST13 & $22 \mathrm{q} 13.2$ & $\mathrm{Y}$ & VIP & Thymic homeostasis & & \\
\hline
\end{tabular}

${ }^{a}$ Comm: Community; ${ }^{b}$ validated miRNA-gene interaction (miRTarBase databank); ER: endoplasmic reticulum. In bold: abundantly expressed miRNAs.

serum amyloid A2 (SAA). SAA proteins induce mitogenic signals in peripheral regulatory T-cells via monocyte activation [123], but their function in thymus is still unknown. Two of the four hubs - TMEM45A and MFSD4 - have functions clearly related to thymic medullar area. TMEM45A codes for a transmembrane protein (TMEM) linked to keratinization and found in Hassall's corpuscles [124]. MFSD4 encodes the transmembrane transporter of MFS (small solute transport) proteins. Gene network analysis revealed that MFSD4 takes part, via $P D E 3 B$ (phosphodiesterase 3B gene), in Foxp3 regulation and Treg homeostasis [125]. DOK7 codes for the docking protein-7, a recruiting protein for Nck $1 / 2$ adapter proteins [126]. Nck $1 / 2$ proteins enhance TCR signaling strength, thus fine-tuning the threshold of thymocyte selection [127, 128]. $P 2 R Y 2$ gene product is the $\mathrm{P} 2 \mathrm{Y} 2$ purinergic receptor, widely expressed by thymic epithelial cells $[129,130$, $131]$ and involved in the phagocytic clearance of apoptotic thymocytes [132].

Community B has four HH genes. Two, ANXA9 and $P I P$, are expressed in epithelial cells and associated to thymic microenvironment. ANXA9 is a high-hub and codes for annexin 9, a periplakin and keratin 8 interacting partner [133]. Keratin 8 is a key promoter of thymic epithelium integrity [134]. C17orf58 is a VIP and codes for a GDP-D-glucose phosphorylase involved in glycoprotein biosynthesis and metabolic repair [135]. PIP is a hub that codes for the prolactin-inducible protein, a regulator of integrin signaling and fibronectin cleavage [136], thus playing a role in keeping thymic microenvironment [137]. Lastly, NLRP12 is a hub that codes for the nucleotidebinding domain and leucine-rich repeat containing receptor (NLRP) 12, which is negative regulator of NF kappa- $\beta$ signaling [138]. NLRP12 has a quite clear role in the negative control of peripheral T-cell response, but its function in thymic pathways remains to be clarified [139].
Community $\mathrm{F}$ also has four $\mathrm{HH}$ genes: two of these genes are related to thymocyte selection and one to anterograde trafficking in Golgi apparatus. $L A P T M 4 B$, a high-hub, encodes a lysosomal-associated transmembrane protein involved in autophagy initiation [140, 141]. Autophagy, as mentioned before, is an essential process for thymocyte selection and T-cell differentiation $[69,70]$. The hub ARHGAPl (a high-hub in DS-DE, Table 1) codes for a RhoGTPase exerting relevant roles in thymocyte development, as commented above [37, 38]. C11orf24 is also a hub and codes for a type I membrane protein that cycles between the Golgi apparatus and the plasma membrane [142]. The third hub in this community, ANKS6, codes for a protein containing nine ankyrin repeats and a SAM domain [143]. ANKS6 is a central protein in the nephronophthisis module [143], but its function in the thymus remains unknown.

Community H harbors only one HH gene: CYFIP1 is a VIP that codes for a clathrin heavy chain binding protein associated to the trans-Golgi network (TGN) [144].

A general picture of DS-DE reveals that almost half of the $\mathrm{HH}$ genes in this network (13 out of 34) are related to roles in thymic homeostasis and cell survival. Thymocyte development and Treg and thymic medullar processes are also well represented gene functions. This scenario is compatible with compensatory processes elicited by trisomy 21 genomic dysregulation. The profile of miRNA target interactions in DS-DE network, described below, corroborates this interpretation. All DS-DE network communities present very low connection weights (Figure 5B) when compared to the values found for CTDE communities. These figures indicate that trisomy 21 dysregulation led to an overall diminished connectivity in the DS-DE network. Indeed, comparatively to CT-DE network, the DS-CT network present low connectivity 
and high modularity, what is evident comparing Figure $2 \mathrm{~A}$ and 2B. The CGCS diagrams (Figure 4) also depict a relative "paucity of connections" between DS-DE communities vis-à-vis CT-DE (Figure 4A and 4B). As a whole, this scenario indicates a comparatively reduced interaction between DS-DE transcriptional modules what could underlie the early-onset thymic dysfunction in DS subjects. The pie chart depicted in Figure 9 shows a compative view of $\mathrm{HH}$ gene functional profiles in CT-DE (Figure 9A) and DS-DE (Figure 9B) network.

\section{MicroRNA target interactions in DS-DE}

In DS-DE four out of the six network communities harbor $\mathrm{HH}$ genes interacting with differentially expressed miRNAs that are abundantly expressed in thymic tissue (Table 2, Figure 7). However, these interactions target just one gene per community. Two of these genes - FBXL5, also a high-hub in CT-DE, and MORN4 - are involved in thymic homeostasis and are located in communities $\mathrm{C}$ and $\mathrm{A}$, respectively. The other two interactions with abundantly expressed miRNAs involve TMEM45A, a gene related to Hassall's corpuscles and located in community $\mathrm{D}$, and $A N K S 6$, located in community F, whose function in thymus is not yet determined. Most of the miRNA- gene interactions occur in communities $\mathrm{A}$ and $\mathrm{C}$ that contain the majority of the HH genes in DS-DE network. These communities also harbor the greater part of the genes involved in thymic homeostasis and cell survival, two distinctive functional features of DS-DE. The vast majority of the miRNAs interacting with $\mathrm{HH}$ genes in DS-DE network are down-regulated, what is well-matched with the overall upregulation of differentially expressed genes in DS group. This scenario probably depicts the outcome of genomic dysregulation caused by the trisomy 21. This subject will be further expanded in the Discussion section.

\section{CO networks}

All CT- and DS-CO communities harboring one or more $\mathrm{HH}$ genes are considered in this section. As it was previously done for DE networks, community characterization includes a brief functional description of $\mathrm{HH}$ genes and their interaction with differentially expressed miRNAs (Tables 3 and 4). Integrative networks for differentially expressed miRNAs and CT-CO and DS$\mathrm{CO}$ high-hierarchy genes appear, respectively, in Figures $8 \mathrm{~A}$ and $8 \mathrm{~B}$, and will be commented in further sections.

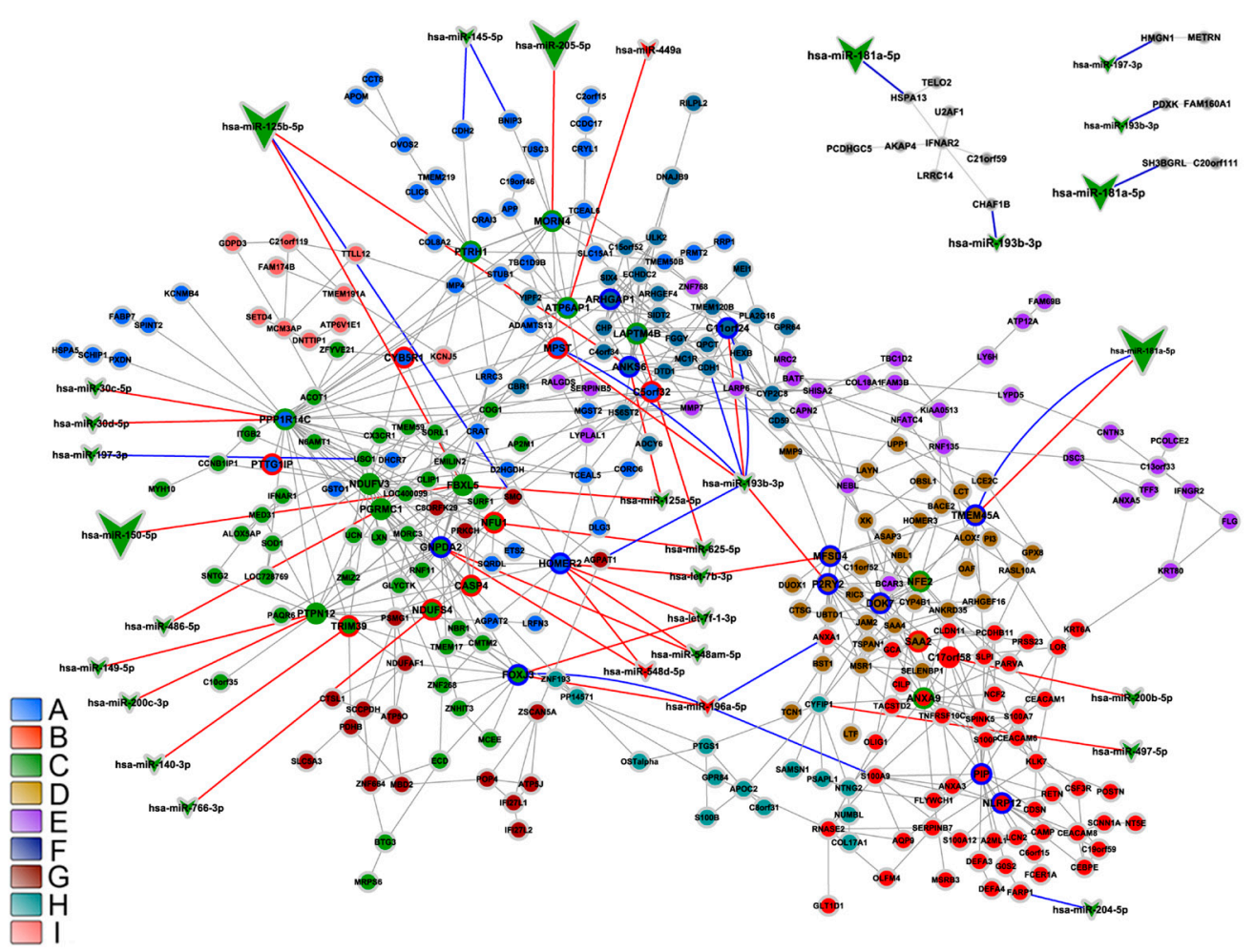

Figure 7: Integrative network analysis for DS-DE network. DS-DE network modular transcriptional repertoire structure (communities) is depicted together with all miRNA-gene validated interactions (blue lines) and the predicted miRNA-gene interactions involving at least one $\mathrm{HH}$ gene (red lines). Communities are distinguished by nodes with different filled colors. Circle or vee nodes represent respectively genes or miRNA. The circles with green, blue or red border indicate respectively high-hubs, hubs or VIPs. The vees filled with red or green colors indicate respectively miRNA hyper- or hipo-expressed. Larger vees indicate abundantly expressed miRNAs. Gene-gene links are indicated by gray lines. Gene node size is proportional to node degree $\left(k_{0}\right)$. 


\section{CT-CO network}

CT-CO network harbors 14 communities containing $\mathrm{HH}$ genes (Table 3 ). Three of these communities, namely $\mathrm{B}, \mathrm{C}$ and $\mathrm{F}$, contain most of the network's HH genes (15 out of 32). The relevance of these communities for network functioning is evidenced in the CGCS diagram presented in Figure $4 \mathrm{C}$ and the biological functions of their $\mathrm{HH}$ genes are described just below.

Community B encompasses eight $\mathrm{HH}$ genes which can be divided in two subsets based on their biological functions: the larger subset encompass six $\mathrm{HH}$ genes related to thymocyte development whereas the smaller subset contains two $\mathrm{HH}$ genes acting on transcriptional regulation.

The larger subset in community B has only one high-hub, SNAP23, which stabilizes SNARE complexes orchestrating ERC-phagosome fusion and enrichment of phagosomes with ERC-derived MHC-I [145]. Moreover, SNARE protein VAMP8 interacts with SNAP23 and has a specific function in the thymic stroma affecting the proliferation and apoptosis of T-lymphocytes during maturation in the thymus [146].
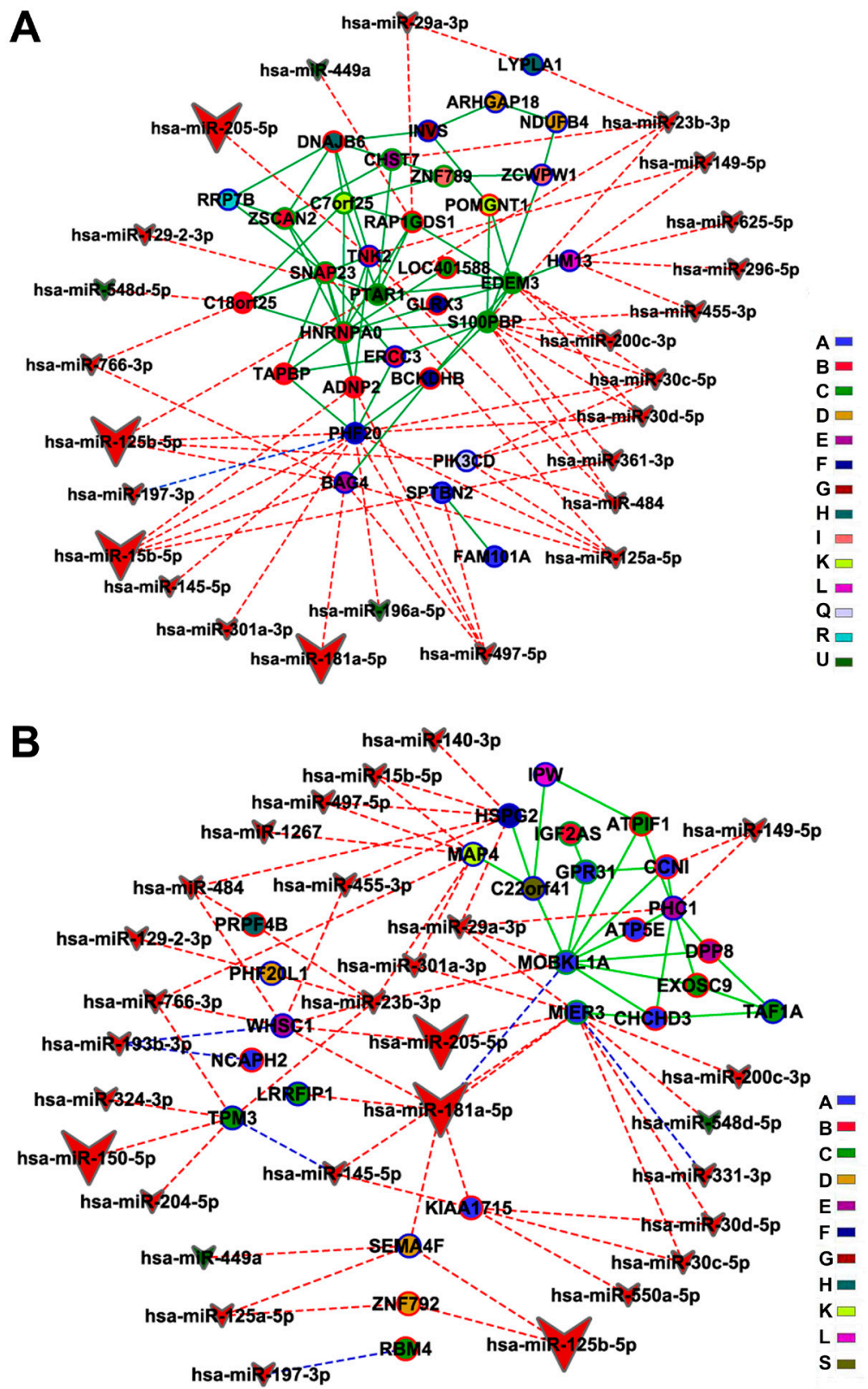

Figure 8: Integrative network analysis for CO subnetworks-miRNA. High-hierarchy gene-miRNA interactions for CT-CO (A) and DS-CO (B) groups are depicted. Hubs, VIPs and High-hubs are indicated respectively by blue, red or green colored node borders. Green line links indicate gene-gene interactions and blue or red doted links indicate respectively validated or predicted miRNA-gene interactions. Different node colors correspond to different communities. 
There are three VIPs in the larger subset of community $\mathrm{B}$. One is $A D N P 2$, which codes for the Activity-dependent Neuroprotective Protein (ADNP) and is probably involved in protecting developing thymocytes from apoptosis, being regulated by the vasoactive intestinal peptide $[147,148,149,150]$. The other VIP is C18orf25 (aliase ARKL1), whose gene product binds CK2 $\beta$ [151], a component of the CD5-CK2 activation pathway that sets the threshold for thymocyte progression to double-positive stage [152]. The third VIP is TAPBP, coding for tapasin, a transmembrane glycoprotein which mediates interaction between newly assembled major histocompatibility complex (MHC) class I molecules and the transporter associated with antigen processing (TAP) [153].

The two remaining genes in this larger subset are hubs. One is $E R C C 3$ (aliase $X P B$ ), a gene with increased expression in Down syndrome [154] which codes for an essential core subunit of the eukaryotic basal transcription factor complex TFIIH [155]: defective TFIIH results, via TAF7, in thymocyte failure to reach DN4 stage [156]. The other hub is $T N K 2$ (aliases $A C K, A C K 1$ ), coding for Cdc42-associated kinase I, a component of EGF receptor signaling complex that regulates EGF receptor degradation [157], thus enhancing the ability of thymic epithelial cells to sustain thymocyte differentiation [158].

The smaller subset in community B is related to transcriptional control and contains two high-hubs: ZSCAN2, which codes for a $\mathrm{C} 2 \mathrm{H} 2$ zinc finger protein involved in transcriptional regulation [159], and $H N R N P A 0$, a RNA binding protein that regulates transcript stability via binding to AU-rich elements of mRNA [160].
Community $\mathrm{C}$ harbors four $\mathrm{HH}$ genes (Table 3 ), and three of these genes are associated to thymocyte maturation processes and thymus development. In fact, EDEM3, a high- hub, has a relevant role in the degradation of misfolded MHC-I, MHC-II and invariant chains in the $\mathrm{ER}$, critical events for antigen presentation in the thymic environment $[161,162,163]$. The other high-hub in this community is $S 100 P B P$, a gene coding for the bindingpartner of S100P, a member of the S100 family of proteins [164]. S100P mediates cell migration and is very similar to S100B: both proteins are interactors of RAGE [164, 165], i.e. the receptor of advanced glycan end-products. RAGE is expressed in thymocytes, thymic macrophages, thymic medulla and Hassal's corpuscles and influences thymic morphology and functions [166], The third gene, a VIP, is RAP $1 G D S 1$, a regulator of thymocyte apoptosis via transglutaminase 2 [167]. The remaining $\mathrm{HH}$ gene in this community is a VIP, LOC401588 (aliase ZNF674-AS1), which codes for an antisense long non-coding RNA of hitherto unknown function.

Community $\mathrm{F}$ harbors three $\mathrm{HH}$ genes (Table 3 ), two of them exerting relevant roles in the thymus and in the immune system. The hub, PHF20, codes for the plant homeodomain protein 20 which regulates $\mathrm{NF}-\kappa \mathrm{B}$ activation [168]. Here is sufficient to say that noncanonical NF- $\kappa \mathrm{B}$ signaling has a significant contribution to central tolerance (and to peripheral tolerance as well) and, consequently, to thymus function [reviewed in 169]. GLRX3 is a VIP and codes for glutaredoxin 3, or PICOT, a regulator of calcineurinNFAT signaling [170]. Calcineurin-NFAT signaling sets the bandwidths for selecting signals during thymocyte
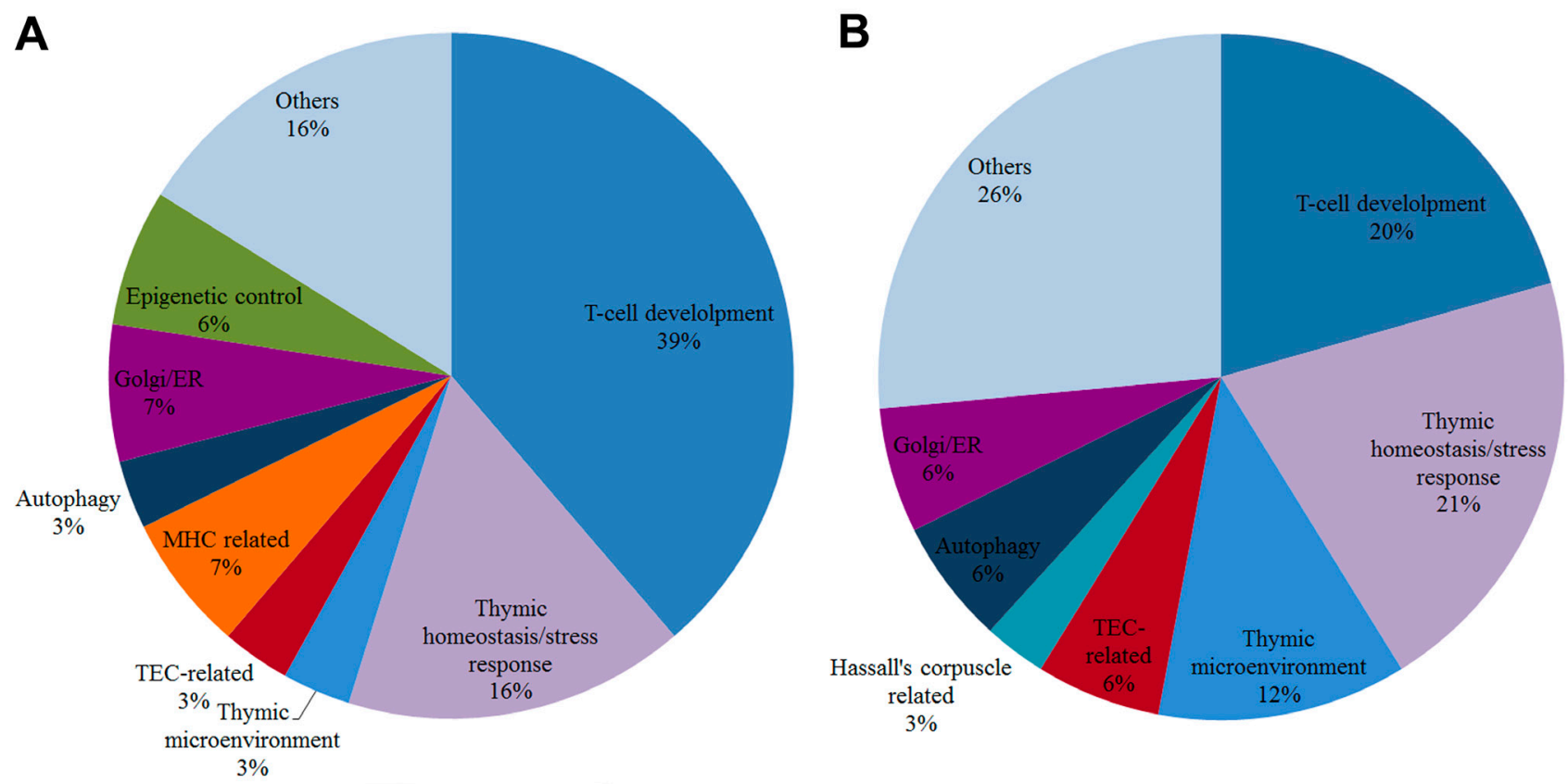

Figure 9: Pie chart of biological functions for high-hierarchy genes in DE networks. Pie chart of HH gene functions in CTDE network (A) and DS-DE network (B). Each slice represents the percentage of genes in a functional category. 
Table 5: Clinical data

\begin{tabular}{|c|c|c|}
\hline Sample ID & Gender & $\begin{array}{l}\text { Age at surgery } \\
(\mathrm{yr} / \mathrm{mo} / \mathrm{d})^{\mathrm{a}}\end{array}$ \\
\hline $\mathrm{DS} 1^{\mathrm{b}}$ & female & $6 \mathrm{mo} 27 \mathrm{~d}$ \\
\hline $\mathrm{DS} 2^{\mathrm{b}}$ & male & $4 \mathrm{mold}$ \\
\hline $\mathrm{DS}^{\mathrm{b}}$ & female & $7 \mathrm{mo} 24 \mathrm{~d}$ \\
\hline $\mathrm{DS} 4^{\mathrm{b}}$ & female & 7 mold \\
\hline DS5 & female & $1 \mathrm{yr} 6 \mathrm{mo}$ \\
\hline $\mathrm{DS} 6^{\mathrm{b}}$ & male & $5 \mathrm{mo} 21 \mathrm{~d}$ \\
\hline $\mathrm{DS} 7^{\mathrm{b}}$ & female & $9 \mathrm{mo14d}$ \\
\hline $\mathrm{DS} 8^{\mathrm{b}}$ & male & $11 \mathrm{~mol} 1 \mathrm{~d}$ \\
\hline $\mathrm{DS}^{\mathrm{b}}$ & male & 1yr6mo \\
\hline DS10 & male & $4 \mathrm{mo} 29 \mathrm{~d}$ \\
\hline $\mathrm{CT} 1^{\mathrm{b}}$ & female & $6 \mathrm{mo} 10 \mathrm{~d}$ \\
\hline $\mathrm{CT}^{\mathrm{b}}$ & female & $1 \mathrm{yr} 5 \mathrm{mo}$ \\
\hline $\mathrm{CT}^{\mathrm{b}}$ & male & 9mold \\
\hline $\mathrm{CT}^{\mathrm{b}}$ & male & 1yr6mo \\
\hline CT5 & female & $6 \mathrm{mo} 24 \mathrm{~d}$ \\
\hline $\mathrm{CT} 6^{\mathrm{b}}$ & female & $6 \mathrm{mo} 9 \mathrm{~d}$ \\
\hline CT7 & male & $2 \mathrm{~mol} 1 \mathrm{~d}$ \\
\hline $\mathrm{CT}^{\mathrm{b}}$ & male & $2 \mathrm{mold}$ \\
\hline $\mathrm{CT} 9^{\mathrm{b}}$ & female & $9 \mathrm{mo} 26 \mathrm{~d}$ \\
\hline $\mathrm{CT} 10^{\mathrm{b}}$ & male & $3 \mathrm{mo19d}$ \\
\hline
\end{tabular}

ayr: years; mo: months; d: days; ${ }^{b}$ samples also used for miRNA analysis.

development [107]. The other VIP is $B C K D H B$ which codes for a mitochondrial protein involved the catabolism of branched-chain amino acids (BCAA). Although BCCA exert widespread effects on the immune system [171], their role in thymus awaits further investigations.

The remaining 11 CT-CO communities harbor only one or two $\mathrm{HH}$ genes However, some of these communities have high connection weights (Figure 5) and their $\mathrm{HH}$ genes exert relevant roles in the thymus, as described below.

Considering the above profile, community $\mathrm{A}$ is quite an exception: it spite of having the largest number of genes (404) in CT-CO network (Figure 4C, Table S2 ), it has the lowest connection weights (Figure 5) and only two $\mathrm{HH}$ genes, both categorized as hubs: SPTBN2 (aliase SCA5), which codes for $\beta$-III spectrin, a protein necessary for endoplasmic reticulum-to-Golgi and post-Golgi protein transport [172], and FAM101A, which codes for a protein (family with sequence similarity 101 , member A) with a hitherto unknown biological function.

The following five communities - ordered according to the number of genes harbored, from higher to lower (Table S2) - are D, E, G, H, and I. Three of these communities, $\mathrm{D}, \mathrm{E}$ and $\mathrm{H}$, include $\mathrm{HH}$ genes playing relevant roles in thymus functioning and will be commented first.

Community D has two hubs. One is ARHGAP18, a regulator of RhoA which interacts with moesin [173] and is involved in T-cell egress from thymus [174]. The other is NDUFB4, which codes for a non-catalytic subunit of the multisubunit NADH:ubiquinone oxidoreductase, the first enzyme complex in the mitochondrial electron transport chain (complex I) [175]. Besides its role in mitochondrial biology, no specific thymic function was assigned to NDUFB4 so far.

Community $\mathrm{E}$ has one hub, $B A G 4$, also known as $S O D D$, which is critical for the regulation of TNF signaling [176, 177]. TNF regulates thymocyte production [178] and interferes with thymic emigration (thymic output) [179]. The other HH gene in this community is CHST7, a high-hub, whose encoded protein catalyzes the sulfation of 6-hydroxyl group of GalNAc in chondroitin. Chondroitin is secreted in large amounts by thymic nurse cells (TNCs) [180]. TNCs provide the microenvironment for secondary T-cell receptor $\alpha$ rearrangement in cortical thymocytes [181].

Community $\mathrm{H}$ also has two $\mathrm{HH}$ genes. One is a VIP, DNAJB6, whose gene product, an Hsp40 family chaperone, is able to enhance the expression of Schlafen 1 [182], a protein expressed in the thymus which regulates 
thymocyte development [183]. The other is LYPLA1, a hub which codes for APT1, an alpha/ beta hydrolase involved in Ras localization and signaling [184]. Ras signaling is critical for setting thymic selection thresholds [185].

Community $\mathrm{G}$ has only one hub, INVS, which codes for the ciliary protein inversin, involved in cell polarity and migration [186], but whose function in thymus remains unknown. Community I is the last in this set and has a rather low connection weight (Figure 5). This community contains just one hub, ZCWPW1, and a high-hub, ZNF789, both coding for zinc finger proteins. ZCWPW was characterized as a histone modification reader [187] and ZNF789 (HGNC 27801) belongs to the $\mathrm{C} 2 \mathrm{H} 2$ zinc finger domain family of transcriptional regulatory proteins.

Finally, and also listed according to the number of nodes/genes in a decreasing order (Table S2), are communities K, L, Q, R and U. Community K include two HH genes. One is POMGNT1, a VIP, which codes for an enzyme that participates in the glycosylation of dystroglycan [188], a crucial step for thymocyte development in mice [189]. The other HH gene community $\mathrm{K}$ is the high-hub C7orf25 (aliase MRLP32), encoding for the mitochondrial ribosome protein L32 (protein synthesis in the mitochondrion). Each of the following four communities harbors a single $\mathrm{HH}$ gene. Community L contains the hub HM13 (aliase SPP) which encodes a signal peptide peptidase involved in MHC-I presentation [190]. In community Q there is a hub, PIK3CD, which codes for class I phosphoinositide-3-kinase delta, a member of the PI3Ks molecule family whose function is to act in concert to protect thymocytes from apoptosis [191]. Community $\mathrm{R}$ harbors another hub, $R R P 7 B$, a ribosomal RNA processing gene with a yet unknown function. Community $\mathrm{U}$, the last in this sequence, has a high-hub, PTARl, which codes for a prenyltransferase

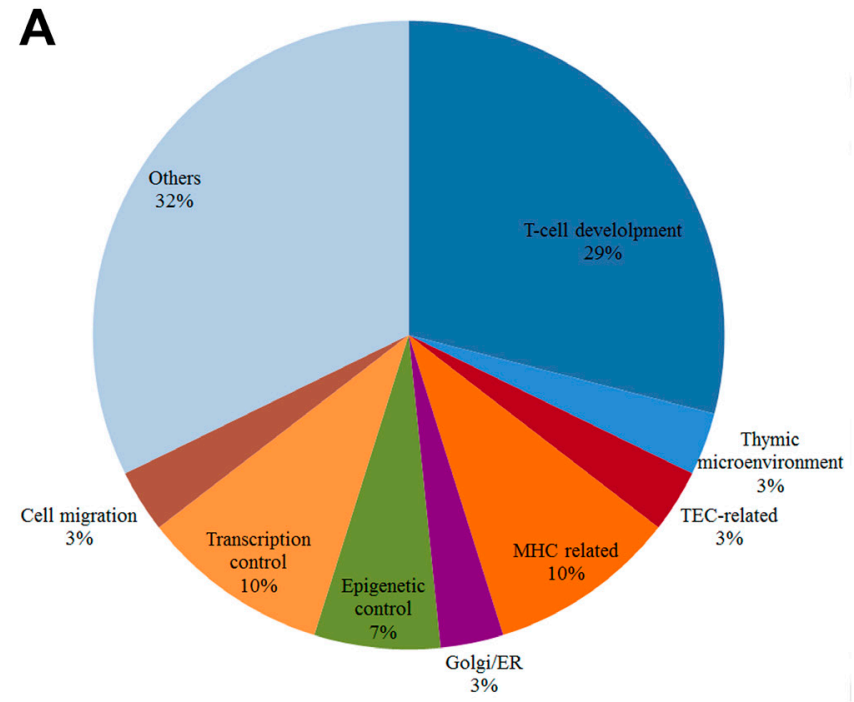

alpha subunit. CD43, an abundant thymocyte cell surface glycoprotein acting on thymocyte development and T-cell activation processes [192], depends on post-translational prenylation for a correct subcellular localization and membrane anchoring [193].

The overall scenario of CT-CO network shows that the communities $\mathrm{B}, \mathrm{C}$ and $\mathrm{F}$ - which contains almost half of the network's $\mathrm{HH}$ genes and have relatively high connection weights (Figures 4C and 5C) - are mostly related to relevant thymic pathways, such as thymocyte development and selection. A similar functional profile was found for communities $\mathrm{D}, \mathrm{E}$ and for community $\mathrm{H}$, which has the highest connection weight in the CT-CO (Figure 5C). Conversely, the other CT-CO communities harbor $\mathrm{HH}$ genes playing a rather ancillary role in support of thymic selection pathways. Hence, CT-CO gene communities would well represent a "canonical" picture of thymus functioning.

\section{MicroRNA target interactions in CT-CO}

In CT-CO network nine out of 14 communities have genes interacting with differentially expressed miRNAs. In six of these communities there are interactions with miRNAs that are abundantly expressed in thymic tissue (Table 3 and Figure 8A). The main targets of these abundantly expressed miRNAs are genes related to thymocyte development. These genes are harbored in communities B, F, E and Q (Table 3). In communities $\mathrm{F}$ and $\mathrm{E}$, the $\mathrm{HH}$ genes involved in such interactions - PHFL20 and BAG4, respectively - are related to the regulation of TNF/NF- $\mathrm{KB}$ signaling, which is critical for relevant thymic pathways, like central tolerance and thymocyte development [169]. These two genes have the highest numbers of miRNA interactions, as well as

Figure 10: Pie chart of biological functions for high-hierarchy genes in CO networks. Pie chart of HH gene functions in CTCO network (A) and DS-CO network (B). Each slice represents the percentage of genes in a functional category.

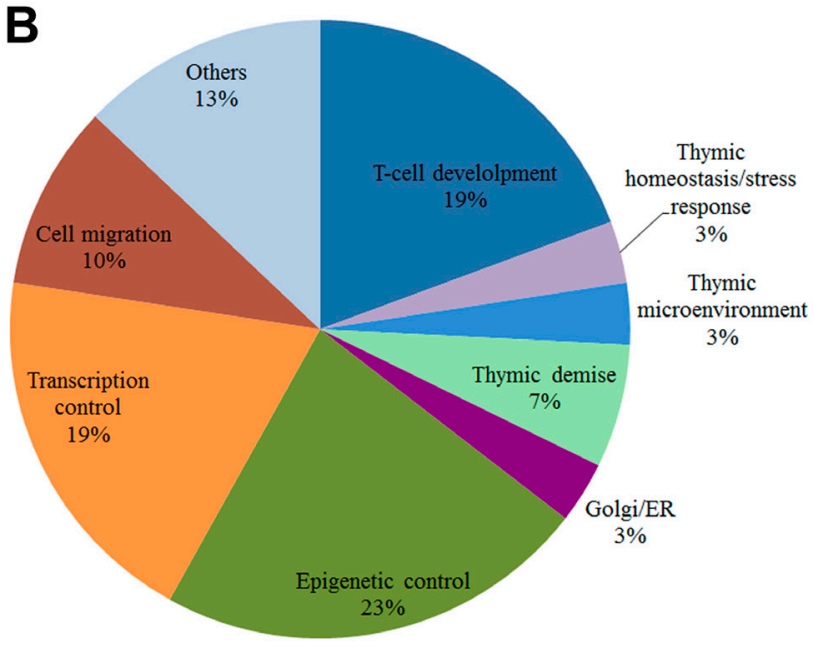


interactions with abundantly expressed miRNAs, in CTCO network (Table 3 and Figure 8A), what indicates that their expression is tightly buffered [94]. A similar situation occurs in community $\mathrm{Q}$, where the sole HH gene, PIK3CD - a hub related to thymocyte protection from apoptosis - is under tight miRNA control. In community $\mathrm{B}$ two genes are targets of abundantly expressed miRNAs - ADNP2 and TNK2 - both related to stromal cells and thymocyte development. Therefore, the genes related to TNF signaling and thymocyte development are those with more miRNA interactions in CT-CO, including abundantly expressed miRNAs.

The other CT-CO communities present lower numbers of miRNA interactions. The $\mathrm{HH}$ genes involved in these interactions are associated to cellular and metabolic processes necessary for thymic functioning (Golgi transport, prenylation, Ras signaling), or in MHC antigen presentation. The only exception is community $\mathrm{C}$ : it has more miRNA interactions than any other community in CT-CO, but none of these interactions are with abundantly expressed miRNAs. All the three $\mathrm{HH}$ genes coding for proteins in this community (the fourth gene is a long non-coding RNA) have miRNA interactions and exert diverse and relevant thymic functions in thymus, as described in the previous section.

\section{DS-CO network}

The DS-CO network has 12 communities containing $\mathrm{HH}$ genes. The majority of these genes (20 out 31) belong to four communities - A, C, D and E - which also concentrate most of the genes with higher numbers of miRNA-gene interactions (Table 4). The relationship among DS-CO communities is depicted in the CGCS diagram presented in Figure 4D. The biological functions of the $\mathrm{HH}$ genes present in all these communities are summarized below.

Community A is the largest DS-CO community (Table S2) both in number of genes (587) and of $\mathrm{HH}$ genes (11). All HH genes in this community are VIPs or high-hubs, therefore playing significant roles in network's functionality and robustness [24, 25]. Moreover, these $\mathrm{HH}$ genes form three distinct functional subsets, as commented below.

The first HH gene subset to be considered in this community - formed by two high-hubs and two VIPs - is mostly related to T-cell development. One of these high-hubs is GPR31, which codes for G protein-coupled receptor 3, a member of GPCR superfamily involved in the activation of ERK1/2, MEK, and NF- $\kappa$ B pathways [194, $84]$ and, therefore, in T-cell development processes [195, 196]. The other high-hub is $M O B K L 1 A$ (aliase $M O B 1 B$ ), which codes for a kinase regulator [197]. Mst1/2-catalyzed $M O B 1 B$ phosphorylation controls, via Dock8, the migratory responses of single positive thymocytes [38]. One of the VIPs, CCNI, codes for cyclin I, a cyclin family member that controls cell cycle progression by regulating cyclin-dependent kinases [198]. Cyclin I belongs to Wnt/ beta-catenin signaling pathway, which regulates the late stages (positive selection) of thymocyte development [199]. The other VIP, NCAPH2, codes for the kleisin- $\beta$ subunit (CAP-H2) of the condensin II, which is crucial for the developmental progression of DN4 thymocytes [200].

The second subset of $\mathrm{HH}$ genes in community $\mathrm{A}$ is constituted by four VIPs associated with thymic metabolic processes. Two of these genes are mitochondrial related: ATP5E, codes for the subunit epsilon of mitochondrial ATP synthase, a key enzyme of mitochondrial energy provision [201], and CHCHD3 codifies for an inner mitochondrial membrane protein, essential for maintaining crista integrity and mitochondrial function [202]. The other two VIPs are: KIAA1715 (aliases LNP, LNP1) a member of Lunapark family which plays a key role in ER tubular network organization [203], and TMOD4 that encodes tropomodulin 4, whose expression is decreased in myogenesis while increased in adipogenesis [204]. It is known that along thymic demise there is a progressive replacement of lymphostromal thymic zones with adipocytes [205], what is also clearly observed in the thymuses of DS infants (see Figure S2).

The third $\mathrm{HH}$ gene subset in community $\mathrm{A}$ is constituted by three high-hubs; all related to epigenetic or transcriptional control mechanisms. Accordingly, MIER 3 codifies for a mesoderm induction early response 1, family member 3, which is an ELM-SANT domain protein and interacts with HDAC1 [206]. The other two HH genes - ZMYM1 and ZNF625 - codify for zinc finger proteins. ZNF625 belongs to the $\mathrm{C} 2 \mathrm{H} 2$ family of zinc finger proteins, which act as trans-regulators of gene expression [207]. ZMYM1 belongs to the MYMtype zinc finger family. Although most members of this family are involved in transcriptional control [208], the specific functional role of the ZMYM1 protein is yet undetermined.

Community $\mathrm{C}$ encompasses three VIPs and three hubs and four of these genes are involved in RNA metabolism and transcriptional control. The VIPs are linked to basic cellular and molecular processes in thymus: ATPIF1 codifies a mitochondrial ATPase inhibitor involved in mitophagy [209], an essential process for the development of thymic iNKT cells in mice and humans [69]; EXOSC9 (aliase RRP45) is involved in RNA turnover and quality control, encoding an exoribonuclease complex which degrades mRNAs containing ARE (AUrich elements) [210]; and $R B M 4$ (aliase $L A R K$ ) codifies a RNA-binding protein involved in alternative splicing of mRNA [211] and in miRNA-guided gene regulation $[211,212]$. Interestingly, RBM4 is significantly decreased in the fetal brain in Down syndrome [213]. Two of the three hubs in community $\mathrm{C}$ also play significant roles in thymus functioning. LRRFIP1, one of these hubs, is a transcriptional repressor and acts with noncoding RNAs 
to control TNF expression [214]. Elevated TNF expression leads to thymic atrophy [215]. Another hub, TPM3, codes for tropomyosin 3 , an actin binding protein involved in actin dynamics and cell migration [216, 217]. As it will be commented in the following section, this gene has many miRNA interactions (validated and predicted) in the thymic environment. The last hub in this community, $T A F 1 A$, codes for a TATA-box binding protein and regulates transcription initiation [218].

Community D has two hubs and one VIP. One hub is PHF20L1, which stabilizes DNA (cytosine-5) methyltransferase 1 (DMNT1) and regulates DNA methylation in cells. This gene is an epigenetic reader (methyllysine reader) and cooperates with writer and eraser to regulate epigenetic inheritance [219]. The other hub is $S E M A 4 F$, which codes for a transmembrane class IV semaphorin (semaphorin 4A) dynamically regulated along thymocyte development [220]. Semaphorins exerts a role on T-cell migration [221] and are miRNA regulated [222]. The VIP is ZNF792, which codes for a C2H2-type zinc finger protein (HGNC 24751), possibly involved in gene expression regulation, but whose specific function in the thymus is as yet unknown.

Community E has three HH genes: one VIP and one hub are associated to thymic T-cell development, and the other hub acts on epigenetic control mechanisms. DDP8, a VIP, codes for dipeptidyl peptidase 8 . This protein is structurally and functionally very similar to dipeptidyl peptidase IV (CD26) [223; 224] and probably exerts the same role as CD26 does in maintaining thymic architecture and thymocyte proliferation during immunosenescence [225]. The hub PHCl (aliase RAE28) codes for a Polycomb gene involved in the repression of HOX genes [226] and the knocking out of this gene in mice causes thymic T-cell arrest at CD4- ${ }^{-}$CD $^{-}$double-negative immature stage [227]. The second hub, WHSC1 (aliases MMSET, NS2) codes for a histone methyltransferase and is a chromatin modifier controlled by a network of miRNAs [228].

Each of the other eight communities in DS-CO network harbors just one $\mathrm{HH}$ gene. However, only in three of these communities - F, H and $\mathrm{K}$ - the $\mathrm{HH}$ genes were found to have interactions with several miRNAs (Table 4). The relatively high number of such interactions indicates that their transcriptional programs are under a somewhat more robust control in network conditions [94]. One of these genes is the hub HSPG2, in community $\mathrm{F}$, which codes for the protein pelercan, an integrant of the lamimin-5 contaning conduits in human thymus. The conduit system is present in the medulla of human thymus and it is responsible for the transport of small blood-born molecules to defined sites within the medulla [229]. In community $\mathrm{H}$ there is the VIP, PRPF4B (aliase $P P R 4$ ), which codes for a serine/threonine protein kinase that binds the Krüppel-like factor 13 (KLF13) in human thymocytes and promotes thymocyte survival
[230]. Lastly, in community $\mathrm{K}$ there is the hub MAP4, which encodes a microtubule binding protein. MAP4 is microtubule-associate and growth regulator protein [231] and interacts with Septin 9 (Sept9) [232] in order to modulate microtubule dynamics. Sept9, a filamentforming protein, exerts a crucial role in the transition from the double-negative stage during thymocyte development [233]. The remaining five $\mathrm{HH}$ genes which do not have assigned miRNA interactions in DS-CO network are described below.

The two single hubs in communities $\mathrm{B}$ and $\mathrm{L}$ (Table 4) are paternally imprinted genes: $I G F 2 A S$, in community B, encodes a long non-coding RNA (lncRNA), the antisense transcript of the insulin-growth factor 2 gene [234], and $I P W$, in community L, codes a lncRNA widely expressed in adult and fetal tissues and associated to Prader-Willi syndrome [235, 236]. The lncRNAs are usually involved in transcriptional control and epigenetic mechanisms, but the specific functions of IGF2AS and $I P W$ in the thymus are presently unknown. The hub in community $\mathrm{G}, R P S 2$, codes for a highly conserved $40 \mathrm{~S}$ subunit ribosomal protein [237]. RPS2 is known to be overexpressed in some human tumors [238], but a specific role for this protein in thymus has not yet been described. Community S has the hub C22orf41 (aliase SYCE3), which codes for the synaptonemal complex central element protein 3 [239], with unknown functions in thymic tissue. Finally, community $\mathrm{Y}$ harbors as its sole $\mathrm{HH}$ gene the hub ST13. This gene codes for the Hsc70-interacting protein (Hip). Hip promotes the functional maturation of the glucocorticoid receptor (GR) [240]. GR is constitutively expressed in thymocytes and plays a significant role in thymic homeostasis [241, 242], mediating physiological and stress responses [242, 243, 244].

As a whole, the functional profile of $\mathrm{HH}$ genes in DS-CO communities differs from that found for CT-CO network. Firstly, the DS-CO network contains a sizable number of $\mathrm{HH}$ genes related to epigenetic mechanisms (seven genes) and transcriptional control (five genes). Altogether, 12 out of $31 \mathrm{HH}$ genes in DS-CO have these functions, against only 5 (all related to transcriptional control) out of 32 in CT-CO. Secondly: in DS-CO network there is a comparatively low number of $\mathrm{HH}$ genes directly involved in thymic selection pathways: just seven against 13 in CT-CO. Interestingly, DS-CO has three $\mathrm{HH}$ genes associated to cell migration processes that present several miRNA interactions (see below), and two HH genes associated to thymic demise (TMOD4 and DPP8). Altogether, the DS-CO network depicts a rather "non-canonical" way of thymus functioning, probably enforced by epigenetic mechanisms. This issue will be further detailed in the Discussion session. The pie chart depicted in Figure 10 shows a compative view of $\mathrm{HH}$ gene functional profiles in CT-CO (Figure 10A) and DS-CO (Figure 10B) network. 


\section{MicroRNA target interactions in DS-CO}

In DS-CO network most of the interactions with abundantly expressed miRNAs, as well a significant part of all gene-miRNA interactions, occur with $\mathrm{HH}$ genes related to epigenetic processes, cell migration and transcription control (Table 4 and Figure 8B). These genes are concentrated in communities A, C, D and $\mathrm{E}$. The high-hub MIER3 in community A is related to epigenetic mechanisms and has the highest number of miRNA interactions in DS-CO (ten, including two abundantly expressed miRNAs). Other genes related to epigenetic mechanisms, like $\mathrm{WHSCl}$ in community E, show a similar "tight control", meaning that the epigenetic processes are very robust in DS-CO. The same considerations apply for $\mathrm{HH}$ genes involved in cell migration processes: for instance, TPM3 in community $\mathrm{C}$ and SEMA4F in community D. Some genes related to transcriptional control, like LRRFIP1 in community $\mathrm{C}$ and ZNF792 in community $\mathrm{D}$, have interaction with abundantly expressed miRNAs. This general picture confirms the importance and robustness of epigenetic, cell migration and transcriptional control processes, and could be considered the functional signature or DS-CO. The two other genes with relevant miRNA interactions in DS-CO are $H S P G 2$, in community $\mathrm{F}$, and MAP4 in community $\mathrm{K}$. The first codes for pelercan, an integrant of the conduit system for small molecules in thymic medullar area, and the former codes for a microtubule protein involved in thymocyte development.

\section{Interactome network analysis}

Only the genes categorized as hubs, VIPs or highhubs were considered in this analysis. MINT and IntAct databases were selected for data generation, which resulted in interactomes with 355 nodes and 1,305 edges for CTDE; 168 nodes and 396 edges for DS-DE; 139 nodes and 313 edges for CT-CO and 161 nodes and 413 edges for DS-CO.

Network visualization and analysis were obtaining after filtering for $\mathrm{HH}$ gene products, excepting the ubiquitously distributed proteins (HSPA1A, APP and RNF11 for CT-DE; CASP4 and PTPN12 for DS-DE; SNAP23, TNK2, GLRX3, HNRNPA0 and DNAJB6 for CT-CO; and ST13, MAP4, TPM3 and PRPF4B for SD$\mathrm{CO})$. These networks include nodes at the first level and all links connecting these nodes, resulting in interactomes with 151 nodes and 319 edges for CT-DE (Figure S3A); 128 nodes and 252 edges for DS-DE (Figure S3B); 76 nodes and 111 edges for CT-CO (Figure S3C) and 98 nodes and 205 edges for DS-CO (Figure S3D). A functional description of the $\mathrm{HH}$ gene products and their interacting protein (first level) based on Gene Ontology (biological process) and PubMed databases is presented in Tables S4-S7 for DE and CO networks.

The interactome analysis shows, for all networks, a reasonable coherence among gene-gene and proteinprotein interaction data, namely, the functional profiles obtained from GCNs and interactome networks are quite similar. In fact, Tables S4-S7 and Figures S3 A-D show a functional association between GCN communities and the first neighbor protein clusters.

\section{qPCR validation}

In order to technically validate the DNA microarray data five up-regulated genes in DS group - DEFA3, DEFA4, LFT, S100P and TMEM45A - were selected for real-time quantitative PCR (qPCR) analysis. The fold-changes for each gene, comparing DS versus CT group's average relative gene expression, confirmed DNA microarray gene expression results (Figure S4).

\section{DISCUSSION}

The impact of trisomy 21 on thymic gene interaction networks was assessed by means of comparative genomic and topological analyses of GCNs - obtained for differential expressed genes and for the global gene expression - in thymic tissues of DS and karyotipically normal subjects. We were able to show that thymic genomic dysregulation in Down syndrome is characterized by distinctive features regarding GCN topology and node hierarchy, derived from widespread changes in the transcriptional program of thymic cells. These data were integrated with miRNA target analysis in order to investigate the mechanism by which trisomy 21 alters the transcriptional program in the thymus of DS subjects.

The trisomy 21 impact in DE networks is clearly evidenced by the pronounced differences in network topology between CT and DS groups (Figure 3A and 3B). The high modularity of DS-DE network contrasts with its reduced connectivity, thus reflecting the disorganization of modular interactions caused by gene dosage imbalance $[11,29,245]$. The CGCS diagrams (Figure 4A and 4B) and the connection weight values obtained for all the communities in CT-DE and DS-DE networks (Figure 5A and $5 \mathrm{~B}$ ) corroborate this picture. The functional profile of HH genes in CT-DE (Table 1) shows that more than one third of these genes are related to T-cell development (12 out of 32), while this functional category encompasses only one fifth of the HH genes in DS-DE (7 out of 34). Conversely, in DS-DE eleven HH genes are involved in thymic homeostasis/microenvironment and stress tolerance processes, whereas in CT-DE these categories sum up only 7 genes. In both DE networks the genes belonging to these most prominent functional categories are targeted by abundantly expressed miRNAs (Tables 1 and 2, Figure 6 and 7). 
The scenario portrayed above show that $\mathrm{HH}$ genes in CT-DE network are mostly associated with the main thymic pathways, such as T-cell development, whereas in DS-DE part of the $\mathrm{HH}$ genes serve to keep up a rather different transcriptional program, where stress tolerance and thymic homeostasis gain relevance. This is quite understandable considering that oxidative damage is an early event (detected in DS pregnancy) in the DS pathogenesis and might contribute to the development of deleterious DS phenotypes [246]. In fact, individuals with DS have high levels of oxidative stress throughout the lifespan [247]. Moreover, thymic stromal cells normally express the amyloid precursor protein, APP [62]. The overexpression of APP, a hallmark of Down syndrome [87], is known to be associated with oxidative stress [248]. Therefore DS thymus development takes place under oxidative stress conditions, what is in agreement with imaging data showing that DS thymic involution starts in utero [16]. The comparative analysis of DE gene networks clearly shows a genomic adaptation of DS-DE network in order to cope with a stressing environment. The transition mechanisms underlying such adaptation will be discussed further in this section.

In the $\mathrm{CO}$ network the adaptive mechanisms commented above are yet more evident. CT-CO network has 14 communities containing $\mathrm{HH}$ genes out of a total of 27 communities (Table S2 and Table 3). However, just three of these 14 communities - B, C and F, with relatively high connection weights - encompass half of the network's $\mathrm{HH}$ genes and these genes are mostly related to relevant thymic pathways, such as thymocyte development and selection (Table 3, Figures $4 \mathrm{C}$ and $5 \mathrm{C}$ ). These three communities and communities E, Q and U, also harboring only genes directly related to T-cell development, happen to contain almost all the targets of abundantly expressed miRNAs in CT-CO network (Table 3, Figure $8 \mathrm{~A}$ ). Therefore, as stated before, $\mathrm{CT}-\mathrm{CO} \mathrm{HH}$ genes and communities seem to be engaged in a "canonical" way of thymus functioning and the transcriptional program behind such way is robustly buffered by miRNA interactions.

The DS-CO network, on the other hand, presents a rather different functional picture. In this network almost half of its $32 \mathrm{HH}$ genes take part in epigenetic and transcriptional control mechanisms (Table 4). These $\mathrm{HH}$ genes (and their communities) also contribute with most of the interactions with abundantly expressed miRNA in DS-CO network. The $\mathrm{HH}$ genes involved in T-cell development are just seven and only one, $M A P 4$, interacts with an abundantly expressed miRNA. Hence, in this network the transcriptional program is biased towards a rather "non-canonical" way of thymus functioning, probably enforced by epigenetic mechanisms acting at the chromatin level and involving miRNAs as well. Interestingly, DS-CO has two $\mathrm{HH}$ genes associated to thymic demise processes, as mentioned before. As a whole, this genomic profile possibly represent an adaptation to precocious thymic involution in DS, where functional and histological alterations occur, such as the cortical atrophy observed in DS subjects included in this study (Figure S2).

In summary, the genomic changes induced by trisomy 21 in the thymic tissue may well be depicted as the breakdown and altered reorganization of transcriptional modules. In terms of network biology, this process implies in a qualitative transition in the gene network from normal state to disease state. This transition involves a transient decrease in network robustness, with loss of network connectivity and subsequent network reorganization, with changes in node hierarchy and under a robust but distinct modular architecture [249]. This kind of network transition happens in GCNs via gain or loss of edges between their constituent nodes, i.e. between their genes $[26,245]$. The identification of these transitions and their leading biological networks has been considered essential for unveiling the molecular and genomic mechanisms underlying chronic diseases, such as cancer or epilepsy $[26,250]$, as well as in genomic-driven network perturbations, such as trisomy 21 [105, 245].

The integration of community structure (modular transcriptional repertoire) and miRNA target analyses allowed the identification of the leading gene coexpression networks (GCNs) that correspond to thymus functioning in karyotypically normal and DS subjects. Here is important to remember that DE networks are subnetworks of the global gene expression networks, or CO networks. The comparative analysis of DE networks probably portrays the "ground zero": the subnetwork transition considering only the genes whose transcription was significantly altered by trisomy 21 . On the other hand, the comparative analysis of $\mathrm{CO}$ networks reveals the derived "shockwaves" of trisomy 21 genomic dysregulation, reflecting its effects on the organ's global transcriptional program. This is in accordance with recent findings showing that trisomy 21 modifies the cell's transcriptional program through expression dysregulation domains dispersed along different chromosomes in the genome [11].

In conclusion, the CT networks - and principally the CT-CO network - would depict the "canonical" way of thymus functioning. Conversely, the DS networks represent a "non-canonical" way, what means the thymic tissue adaptation to trisomy 21 genomic dysregulation and it's functioning under stressed conditions. This adaptation is probably driven by epigenetic mechanisms acting at chromatin level and through the miRNA control of transcriptional programs involving the networks' highhierarchy genes. 


\section{MATERIALS AND METHODS}

\section{Patients}

Thymic tissue samples were obtained from 10 Down syndrome subjects and 10 karyotypically normal subjects that underwent cardiac surgery at Instituto Dante Pazzanese de Cardiologia, São Paulo, Brazil. All patients were gender- and age- matched (age ranging from two to 18 months) (Table 5, Figure S5). This research has been approved by the research ethics committee of Instituto Dante Pazzanese de Cardiologia under number 4287. A written informed consent was obtained from all patients.

\section{Thymic tissue specimens}

Fresh corticomedullar sections of thymic tissue were obtained at surgery room from DS subjects (DS group) and karyotipically normal subjects (CT group) and were immediately preserved with RNAlater (Qiagen cat. no. 76106, Valencia, CA). Haematoxylin and eosin (HE) histology was performed for all thymic specimens and revealed typical cortical atrophy [12] in DS samples (Figure S2). Detailed morphometric and immunohistochemical analyses of this material are beyond the scope of this paper and will be published elsewhere.

\section{Total RNA extraction}

Thymus tissue explants $\left(3-4 \mathrm{~mm}^{3}\right)$ were homogenized with TissueRupter (Qiagen, cat. no. 9001272 Valencia, CA) and total RNA was extracted from the homogenates using the RNeasy Lipid Tissue Kit (Qiagen cat. no. 74804, Valencia, CA) according to the manufacturer's instructions. RNA quality was assessed on the Agilent BioAnalyzer 2100 (Agilent, Santa Clara, CA). All samples were stored at $-80{ }^{\circ} \mathrm{C}$ until used in hybridization experiments.

\section{Microarray hybridization and gene expression analysis}

In order to determine gene expression profiles, $4 \times 44 K$ v. 2 DNA microarrrays (Whole Human Genome Microarray Kit, Agilent Technologies, cat no. G4845A, Santa Clara, CA) were used. The procedures for hybridization using the fluorescent dye Cy3 followed the manufacturer's protocols (One-Color MicroarrayBased Gene Expression Analysis - Quick Amp Labeling). The images were captured by the reader Agilent Bundle according to the parameters recommended for bioarrays and extracted by Agilent Feature Extraction software version 9.5.3. Spots with two or more flags (low intensity, saturation, controls, etc.) were considered as NA, that is, without valid expression value. The $\mathrm{R}$ software version 2.11.1 [251] and an in house script were used for: i) sample grouping (CT or DS groups); ii) excluding transcript spots presenting three or more NAs per group; iii) converting gene expression values to log base 2 . Through this procedure we identified 12,989 valid GO annotated genes for DS and CT groups. By means of the TMEV software version 4.6.1 [252] we obtained the 538 differentially expressed (DE) GO annotated genes using the Significance Analysis of Microarrays (SAM) procedure. All microarray raw data have been deposited in GEO public database (http://www.ncbi.nlm.nih.gov/geo), a MIAME compliant database, under accession number GSE69210.

\section{MicroRNA microarray hybridization and analysis}

Total RNA samples obtained from eight Down syndrome subjects and eight karyotypically normal subjects (Table 5) were used to determine and evaluate the miRNA profiles. Whole human miRNA of $8 \times 15 \mathrm{~K}$ DNA microarrays (Human miRNA Microarray Kit V3, G4470C, Agilent Technologies), containing probes for 866 human and 89 viral miRNAs based on Sanger miRBase (release 12.0) were used. The procedures for hybridization followed the protocols provided by the manufacturer's instructions (miRNA Complete Labeling and Hyb Kit, Agilent Technologies, cat. no. 5190-0456). The images were captured by the reader Agilent Bundle according to the parameters recommended for bioarrays and extracted by Agilent Feature Extraction software version 10.7.3. Spots with two or more flags (low intensity, saturation, controls, etc.) were considered as NA, that is, without valid expression value. The $\mathrm{R}$ software version 2.11.1 [251] and an in house script were used for: i) sample grouping (CT or DS groups); ii) excluding transcript spots presenting two or more NAs per group; iii) converting miRNA expression values to $\log$ base 2 . Through this procedure we identified 641 valid miRNAs for DS and CT groups. Differentially expressed miRNAs were obtained by means of the TMEV software version 4.6.1 [252] using the unpaired t-test $(\mathrm{p}<0.05)$. All microarray raw data have been deposited in GEO public database (http://www.ncbi. nlm.nih.gov/geo), a MIAME compliant database, under accession number GSE70573.

\section{Gene coexpression networks (GCNs): visualization, analysis and community detection}

Gene coexpression networks for differentially expressed GO annotated genes (DE networks) for all valid GO annotated genes, namely complete networks (CO networks), were constructed for DS and CT groups based on Pearson's correlation, as we previously described 
[24]. Pearson's correlation identifies sets of genes which covaries (positively or negatively), thus allowing us to construct networks by considering nodes as genes, with edges inferred if a pair presents high absolute value of correlation. Specifically, we define a correlation threshold that determines if edges are present or absent in the resulting network. This is done in a way that all nodes are connected to the major component and the network is stable in the sense that slight changes in the threshold value do not significantly affect its topological structure [24]. Networks were tested for scale free status by Kolmogorov-Smirnov (K-S) statistics, i.e. power law distributions in empirical data [253].

As these networks may grow larger in the number of components (e.g. hundreds or thousands) or present very intricate connections between them (such as hierarchical or modular structure), it becomes mandatory the use complex network analysis methodology to better characterize such networks $[25,33,254]$.

We developed a network methodology for GCN visualization and analysis $[24,25,26]$ that allows the categorization of network nodes according to nodecentered connectivity taken along distinct hierarchical levels of gene-gene neighborhoods [255, 32]: hubs are highly connected nodes, VIPs - standing for "Very Important Person", an acronym initially coined for the study of social networks [256] and equivalent to the term "date-hubs" in biological network papers [41] have low node degree but connect only with hubs, and high-hubs have VIP status and high overall number of connections. We classified network nodes as VIPs, hubs or high-hubs by obtaining the node degree, $k_{0}$, and the first level concentric node degree, $k_{l}$, which takes into account all node connections leaving from its immediate neighborhood, then projecting all node values in a $k_{0} v s k_{l}$ plot. All calculations were done by using Python program and the conceptual framework is described at http:// cyvision.if.sc.usp.br/ bant/hierarchical/. Along this paper, hubs, VIPs and high-hubs are sometimes designated highhierarchy genes $(\mathrm{HH})$.

\section{Connectivity}

The network connectivity $\mathrm{k}$ for non-directed networks was calculated by $\mathrm{k}=2 \mathrm{~L} / \mathrm{N}$, where $\mathrm{L}$ stands for the number of edges and $\mathrm{N}$ for the number of nodes [257].

\section{Community detection}

Community detection in complex networks is usually accomplished by discovering the network modular structure that optimizes the modularity measurement. Modularity takes into account the relationship between the number of links inside a community and between nodes in distinct communities compared to the random model [257,
258]. A diverse range of optimization techniques exist to optimize the modularity. Here we applied the method proposed by Blondel et al. [259] which attains good modularity values and presents excellent performance.

\section{Connection weight between communities}

Connection weight values were obtained for all the constituent communities of DE networks and for all the CO networks' communities harboring high-hierarchy genes. The weight of connections $W_{\alpha \beta}$, which also comprise the elements of the mixing matrix [258], is taken as the stochastic probability of a vertex in the community $\alpha$ connecting to a vertex in $\beta$, which can also be given as: $W_{\alpha \beta}=E_{\alpha \beta} /(|\alpha||\beta|)$, where $E_{\alpha \beta}$ stands for the total number of edges between the two communities $\alpha$ and $\beta$ [260, 261]. The normalization in $W_{\alpha \beta}$ is needed to account for the distinct community sizes present in the network, otherwise the edges weights would become biased towards the larger communities.

\section{Coarse-grained community structure}

As a complementary analysis for the community detection, each GCN was rearranged in a new network accounting only for the relationships between each community, also known as coarse-grained community structure (CGCS) [41, 260, 262]. Here the CGCS was generated by contracting all nodes inside each community into a single community node; likewise, edges are summarized in terms of the connection weight between such communities, $W_{\alpha \beta}$. This structure can also be obtained directly by considering the mixing matrix [258] as an adjacency matrix of the new network, which has been used to summarize the community organization of many knowledge networks such as citation networks [260,262].

\section{Structural analysis of the CO communities' subnetworks}

Complete sets of gene expression values were obtained from each one of the $\mathrm{CO}$ network communities (CT and DS networks) were used for generating their corresponding subnetworks using Pearson's correlation and the same link strength threshold adopted for $\mathrm{CO}$ networks. Only communities harboring 100 or more genes/nodes were considered in this analysis [257]. This approach allowed the characterization of subnetworks' topology and connectivity.

\section{MicroRNA target analyses}

Analyses of the differentially expressed miRNAs interactions with all selected high-hierarchy genes 
from DE and CO networks were performed based on the following miRNAs databases: miRTarBase, an experimentally validated miRNA-target gene interaction database, and mirPath database (predicted miRNAtarget gene interaction). The miRNA-gene interaction networks and integrative networks (high-hierarchy gene coexpression subnetworks-miRNA) were visualized through Cytoscape 3D.

\section{Interactome analysis}

The interactome networks were constructed using an in house free web tool developed by Leandro de A. Lima and Renato D. Puga from Centro Internacional de Pesquisa e Ensino (CIPE) - A. C. Camargo Cancer Center (http://bioinfo.lbhc.hcancer.org.br/cgi-bin/ interactomegraph/index.cgi). Only categorized hubs, VIPs and high hubs genes were considered in this analysis. MINT and IntAct databases were selected for comparison and data generation. Data analysis and visualization were accomplished through Cytoscape (version 3.1.0, www. cytoscape.org).

\section{qPCR for microarray technical validation}

Differential gene expression data were validated through quantitative real-time polymerase chain reaction (qPCR). Specific primers for five selected genes (Table S8) were designed using the Primer-BLAST (Primer3 Input, version 0.4.0 and BLAST, available at http://www. ncbi.nlm.nih.gov/tools/primer-blast/). All samples were amplified in triplicates. Amplification reactions were performed in a $25 \mathrm{uL}$ final volume containing $1 \mathrm{X}$ SYBR Green mix (Quantitec SYBR Green PCR kit, QIAGEN, Hilden, DE), 10 pmol of each primer and $2 \mu \mathrm{L}$ cDNA (1/10 dilution, synthesized from $1 \mu \mathrm{g}$ of total RNA). Real time PCR amplifications were performed in Applied Biosystems StepOne Plus Real Time PCR System with StepOne software (Applied Biosystems, Foster City, CA, USA) with the following cycling parameters: an initial hot start of $95^{\circ} \mathrm{C}$ for $15 \mathrm{~min}$ followed by 50 cycles of $95^{\circ} \mathrm{C}$ for $15 \mathrm{~s}$ and $60^{\circ} \mathrm{C}$ for $30 \mathrm{~s}$. In order to normalize qPCR reactions, GAPDH was included as reference gene after checking that amplification curves for 10 different RNA samples ( 5 from DS and 5 from CT) yielded essentially the same results. Relative expression was determined by the relative standard curve method [263] and presented as fold change comparing DS versus CT mean values.

\section{CONFLICT OF INTEREST}

The authors declare that the research was conducted in the absence of any commercial or financial relationships that could be construed as a potential conflict of interest.

\section{FUNDING}

This work was funded by Fundação de Amparo à Pesquisa do Estado de São Paulo (FAPESP) research grant 2009/53443-1 and Conselho Nacional de Desenvolvimento Científico e Tecnológico $(\mathrm{CNPq})$ grants 305635/2009-3 and 307626/2014-8 to CAM-F. MC-S was funded by FAPESP grants 2008/58238-4 and 2014/504899. L da FC was funded by FAPESP grants 2005/005875 and 2011/50761-2 and CNPq grants 301303/06-1 and $73583 / 2008-0$. CAM-F and L da FC are funded by FAPESP-MCT/CNPq/PRONEX grant 2011/50761-2. FNS is the recipient of a CAPES fellowship.

\section{REFERENCES}

1. Anderson G, Takahama Y. Thymic epithelial cells: working class heroes for $\mathrm{T}$ cell development and repertoire selection. Trends Immunol. 2012; 33:256-263.

2. Jablonska-Mestanova V, Sisovsky V, Danisovic L, Polak S, Varga I. The normal human newborns thymus. Bratisl Lek Listy. 2013; 114:402-408.

3. Macedo C, Evangelista AF, Magalhães DA, Fornari TA, Linhares LL, Junta CM, Silva GL, Sakamoto-Hojo ET, Donadi, EA, Savino W, Passos G A. Evidence for a network transcriptional control of promiscuous gene expression in medullary thymic epithelial cells. Mol Immunol. 2009; 46:3240-3244.

4. Abramson J, Giraud M, Benoist C, Mathis D. Aire's partners in the molecular control of immunological tolerance. Cell. 2010; 140:123-135.

5. Mingueneau M, Kreslavsky T, Gray D, Heng T, Cruse R, Ericson J, Bendall S, Spitzer MH, Nolan GP, Kobayashi $\mathrm{K}$, von Boehmer $\mathrm{H}$, Mathis $\mathrm{D}$, Benoist $\mathrm{C}$, et al. The transcriptional landscape of $\alpha \beta \mathrm{T}$ cell differentiation. Nat Immunol. 2013; 14:619-632.

6. Yui MA, Rothenberg EV. Developmental gene networks: a triathlon on the course to T cell identity. Nat Rev Immunol. 2014; 14:529-545.

7. Mégarbané A, Ravel A, Mircher C, Sturtz F, Grattau Y, Rethoré MO, Delabar JM, Mobley WC. The 50th anniversary of the discovery of trisomy 21 : the past, present, and future of research and treatment of Down syndrome. Genet Med. 2009; 11:611-616.

8. Aït Yahya-Graison E, Aubert J, Dauphinot L, Rivals I, Prieur M, Golfier G, Rossier J, Personnaz L, Creau N, Bléhaut H, Robin S, Delabar JM, Potier MC. Classification of human chromosome 21 gene-expression variations in Down syndrome: impact on disease phenotypes. Am J Hum Genet. 2007; 81:475-491.

9. Prandini P, Deutsch S, Lyle R, Gagnebin M, Delucinge Vivier C, Delorenzi M, Gehrig C, Descombes P, Sherman S, Dagna Bricarelli F, Baldo C, Novelli A, Dallapiccola B, et al. Natural gene-expression variation in Down syndrome modulates the outcome of gene-dosage imbalance. Am J 
Hum Genet. 2007; 81:252-263.

10. Korbel JO, Tirosh-Wagner $\mathrm{T}$, Urban AE, Chen $\mathrm{XN}$, Kasowski M, Dai L, Grubert F, Erdman C, Gao MC, Lange K, Sobel EM, Barlow GM, Aylsworth AS, et al. The genetic architecture of Down syndrome phenotypes revealed by high-resolution analysis of human segmental trisomies. Proc Natl Acad Sci USA. 2009; 106:12031-12036.

11. Letourneau A, Santoni FA, Bonilla X, Sailani MR, Gonzalez D, Kind J, Chevalier C, Thurman R, Sandstrom RS, Hibaoui Y, Garieri M, Popadin K, Falconnet E, et al. Domains of genome-wide gene expression dysregulation in Down's syndrome. Nature. 2014; 508:345-350.

12. Levin SM, Schlesinger Z, Handzel T, Hahn T, Altman Y, Czernobilsky B, Boss J. Thymic deficiency in Down's syndrome. Pediatrics. 1979; 63:80-87.

13. Larocca LML, Lauriola FO Ranelletti M, Piantelli M, Maggiano N, Ricci R, Capelli A. Morphological and immunohistochemical study of Down syndrome thymus. Am J Med Genet. 1990; Suppl 7:225-230.

14. Kusters MA, Gemen EF, Verstegen RH, Wever PC, DE Vries E. Both normal memory counts and decreased naive cells favor intrinsic defect over early senescence of Down syndrome T lymphocytes. Pediatr Res. 2010; 67:557-562.

15. De Leon-Luis J, Santolaya J, Gamez F, Pintado P, Perez $\mathrm{R}$, Ortiz-Quintana L. Sonographic thymic measurements in Down syndrome fetuses. Prenat Diagn. 2011; 31:841-845.

16. Karl K, Heling KS, Sarut Lopez A, Thiel G, Chaoui R. Thymic-thoracic ratio in fetuses with trisomy 21,18 or 13 . Ultrasound Obstet Gynecol. 2012; 40:412-417.

17. Bloemers BL, Bont L, de Weger RA, Otto SA, Borghans JA, Tesselaar K. Decreased thymic output accounts for decreased naive $\mathrm{T}$ cell numbers in children with Down syndrome. J Immunol. 2011; 186:4500-4507.

18. Lorenzo LP Shatynski KE, Clark S, Yarowsky PJ, Williams MS. Defective thymic progenitor development and mature T-cell responses in a mouse model for Down syndrome. Immunology. 2013; 139:447-458.

19. Pellegrini FP, Marinoni M, Frangione V, Tedeschi A, Gandini V, Ciglia F, Mortara L, Accolla RS, Nespoli L. Down syndrome, autoimmunity and T regulatory cells. Clin Exp Immunol. 2012; 169:238-243.

20. Lima FA, Moreira-Filho CA, Ramos PL, Brentani H, Lima L de A, Arrais M, Bento-de-Souza LC, Bento-de-Souza L, Duarte MI, Coutinho A, Carneiro-Sampaio M. Decreased AIRE expression and global thymic hypofunction in Down syndrome. J Immunol. 2011; 187:3422-3430.

21. Giménez-Barcons M, Casteràs A, Armengol Mdel P, Porta E, Correa PA, Marín A, Pujol-Borrell R, Colobran R. Autoimmune predisposition in Down syndrome may result from a partial central tolerance failure due to insufficient intrathymic expression of AIRE and peripheral antigens. J Immunol. 2014; 193:3872-3879.

22. Xu Y, Li W, Liu X, Chen H, Tan K, Chen Y, Tu Z, Dai Y. Identification of dysregulated microRNAs in lymphocytes from children with Down syndrome. Gene. 2013; 530:278286.

23. Xu Y, Li W, Liu X, Ma H, Tu Z, Dai Y. Analysis of microRNA expression profile by small RNA sequencing in Down syndrome fetuses. Int J Mol Med. 2013; 32:11151125 .

24. Bando SY, Silva FN, Costa Lda F, Silva AV, Pimentel-Silva LR, Castro LH, Wen HT, Amaro E, Moreira-Filho CA. Complex network analysis of CA3 transcriptome reveals pathogenic and compensatory pathways in refractory temporal lobe epilepsy. PLoS One. 2013; 8:e79913.

25. Moreira-Filho CA, Bando SY, Bertonha FB, Silva FN, Costa L da F. Methods for gene coexpression network visualization and analysis. In: Passos GA, editor. Transcriptomics in Health and Disease. Switzerland: Springer International Publishing. 2014; p:79-94.

26. Moreira-Filho CA, Bando SY, Bertonha FB, Iamashita P, Silva FN, Costa LdaF, Silva AV, Castro LH, Wen HT. Community structure analysis of transcriptional networks reveals distinct molecular pathways for early- and late-onset temporal lobe epilepsy with childhood febrile seizures. PLoS One. 2015; 10:e0128174.

27. Chaussabel D, Baldwin N. Democratizing systems immunology with modular transcriptional repertoire analyses. Nat Rev Immunol. 2014; 14:271-280.

28. Gaiteri C, Ding Y, French B, Tseng GC, Sibille E. Beyond modules and hubs: the potential of gene coexpression networks for investigating molecular mechanisms of complex brain disorders. Genes Brain Behav. 2014; 13:1324.

29. Barabási AL and Oltvai ZN (2004) Network biology: understanding the cell's functional organization. Nat Rev Genet. 2004; 5:101-113.

30. Hoang SA, Bekiranov S. The network architecture of the Saccharomyces cerevisiae genome. PLoS One. 2013; 8:e81972.

31. Narayanan T, Subramaniam S. Community structure analysis of gene interaction networks in Duchenne muscular dystrophy. PLoS ONE. 2013; 8:e67237.

32. Costa L da F, Rodrigues FA, Travieso G, Villas Boas PR. Characterization of complex networks: A survey of measurements. Advances in Physics. 2007; 56:167-242.

33. Barabási AL, Gulbahce N, Loscalzo J. Network Medicine: a network based approach to human disease. Nat Rev Genet. 2011; 13:56-68.

34. Ruiz JC, Walker SD, Anderson SA, Eisenstein RS, Bruick RK. F-box and leucine-rich repeat protein 5 (FBXL5) is required for maintenance of cellular and systemic iron homeostasis. J Biol Chem. 2013; 288:552-560.

35. Ruiz JC, Bruick RK. F-box and leucine-rich repeat protein 5 (FBXL5): sensing ntracellular iron and oxygen. J Inorg Biochem. 2014; 133:73-77.

36. Sharifi S, Daghighi S, Motazacker MM, Badlou B, Sanjabi B, Akbarkhanzadeh A, Rowshani AT, Laurent S, 
Peppelenbosch MP, Rezaee F. Superparamagnetic iron oxide nanoparticles alter expression of obesity and T2Dassociated risk genes in human adipocytes. Sci Rep. 2013; $3: 2173$.

37. Henning SW, Galandrini R, Hall A, Cantrell DA. The GTPase Rho has a critical regulatory role in thymus development. EMBO J. 1997; 16:2397-2407.

38. Mou F, Praskova M, Xia F, Van Buren D, Hock H, Avruch J, Zhou D. The Mst1 and Mst2 kinases control activation of rho family GTPases and thymic egress of mature thymocytes. J Exp Med. 2012; 209:741-759.

39. Sollberger G, Strittmatter GE, Kistowska M, French LE, Beer HD. Caspase-4 is required for activation of inflammasomes. J Immunol. 2012; 188:1992-2000.

40. Youm YH, Kanneganti TD, Vandanmagsar B, Zhu X, Ravussin A, Adijiang A, Owen JS, Thomas MJ, Francis J, Parks JS, Dixit VD. The Nlrp3 inflammasome promotes age-related thymic demise and immunosenescence. Cell Rep. 2012; 1:56-68.

41. Zhu X, Gerstein M, Snyder M. Getting connected: analysis and principles of biological networks. Genes Dev. 2007; 21:1010-1024.

42. Winkler GS. The mammalian anti-proliferative BTG/Tob protein family. J Cell Physiol. 2010; 222:66-72.

43. Konrad MA, Zúñiga-Pflücker JC. The BTG/TOB family protein TIS21 regulates stage-specific proliferation of developing thymocytes. Eur J Immunol. 2005; 35:30303042 .

44. Thurnher M, Gruenbacher G. T lymphocyte regulation by mevalonate metabolism. Sci Signal. 2015; 8:re4.

45. Lustig A, Carter A, Bertak D, Enika D, Vandanmagsar B, Wood W, Becker KG, Weeraratna AT, Taub DD. Transcriptome analysis of murine thymocytes reveals ageassociated changes in thymic gene expression. Int $\mathrm{J}$ Med Sci. 2009; 6:51-64.

46. Forés-Martos J, Cervera-Vidal R, Chirivella E, RamosJarero A, Climent J. A genomic approach to study Down syndrome and cancer inverse comorbidity: untangling the chromosome 21. Front Physiol. 2015; 6:10.

47. Sultan M, Piccini I, Balzereit D, Herwig R, Saran NG, Lehrach H, Reeves RH, Yaspo ML. Gene expression variation in Down's syndrome mice allows prioritization of candidate genes. Genome Biol. 2007; 8:R91.

48. Hanley PJ, Xu Y, Kronlage M, Grobe K, Schön P, Song J, Sorokin L, Schwab A, Bähler M. Motorized RhoGAP myosin IXb (Myo9b) controls cell shape and motility. Proc Natl Acad Sci U S A. 2010; 107:12145-12150.

49. Sabbir MG, Prieditis H, Ravinsky E, Mowat MR. The role of Dlc1 isoform 2 in K-Ras2(G12D) induced thymic cancer. PLoS One. 2012; 7:e40302.

50. Wang T, Wong KK, Hong W. A unique region of RILP distinguishes it from its related proteins in its regulation of lysosomal morphology and interaction with Rab7 and Rab34. Mol Biol Cell. 2004; 15:815-826.
51. Smith RD, Lupashin VV. Role of the conserved oligomeric Golgi (COG) complex in protein glycosylation. Carbohydr Res. 2008; 343:2024-2031.

52. Willett R, Ungar D, Lupashin V. The Golgi puppet master: COG complex at center stage of membrane trafficking interactions. Histochem Cell Biol. 2013; 140:271-283

53. Kasahara T, Kato T. Nutritional biochemistry: A new redoxcofactor vitamin for mammals. Nature. 2003; 422:832.

54. Humphrey BD, Klasing KC. The acute phase response alters cationic amino acid transporter expression in growing chickens (Gallus gallus domesticus). Comp Biochem Physiol A Mol Integr Physiol. 2005; 142:485-494.

55. Azmi PB, Seth AK. The RING finger protein 11 binds to Smad4 and enhances Smad4-dependant TGF-beta signalling. Anticancer Res. 2009; 29:2253-2263.

56. Hauri-Hohl M, Zuklys S, Holländer GA, Ziegler SF. A regulatory role for TGF- $\beta$ signaling in the establishment and function of the thymic medulla. Nat Immunol. 2014; 15:554-561.

57. Tome ME, Briehl MM. Thymocytes selected for resistance to hydrogen peroxide show altered antioxidant enzyme profiles and resistance to dexamethasone-induced apoptosis. Cell Death Differ. 2001; 8:953-961.

58. Tew KD, Townsend DM. Glutathione-s-transferases as determinants of cell survival and death. Antioxid Redox Signal. 2012; 17:1728-1737.

59. Pastore A, Piemonte F. S-Glutathionylation signaling in cell biology: progress and prospects. Eur J Pharm Sci. 2012; 46:279-292.

60. 58. Boada-Romero E, Letek M, Fleischer A, Pallauf K, Ramón-Barros C, Pimentel-Muiños FX. TMEM59 defines a novel ATG16L1-binding motif that promotes local activation of LC3. EMBO J. 2013; 32:566-582.

61. Ullrich S, Münch A, Neumann S, Kremmer E, Tatzelt J, Lichtenthaler SF. The novel membrane protein TMEM59 modulates complex glycosylation, cell surface expression, and secretion of the amyloid precursor protein. J Biol Chem. 2010; 285:20664-20674.

62. Laky K, Annaert W, Fowlkes BJ. Amyloid precursor family proteins are expressed by thymic and lymph node stromal cells but are not required for lymphocyte development. Int Immunol. 2009; 21:1163-1174.

63. Osman W, Laine S, Zilliacus J. Functional interaction between the glucocorticoid receptor and GANP/MCM3AP. Biochem Biophys Res Commun. 2006; 348:1239-1244.

64. Radulescu AE, Mukherjee S, Shields D. The Golgi protein p115 associates with gamma-tubulin and plays a role in Golgi structure and mitosis progression. J Biol Chem. 2011; 286:21915-21926.

65. Mine T, Harada K, Matsumoto T, Yamana H, Shirouzu $\mathrm{K}$, Itoh K, Yamada A. CDw108 expression during T-cell development. Tissue Antigens. 2000; 55:429-436.

66. Jongbloets BC, Ramakers GM, Pasterkamp RJ. Semaphorin7A and its receptors: pleiotropic regulators 
of immune cell function, bone homeostasis, and neural development. Semin Cell Dev Biol. 2013; 24:129-138.

67. Dillon SC, Zhang X, Trievel RC, Cheng X. The SET-domain protein superfamily: protein lysine methyltransferases. Genome Biol. 2005; 6:227.

68. Popovic D, Akutsu M, Novak I, Harper JW, Behrends C, Dikic I. Rab GTPase-activating proteins in autophagy: regulation of endocytic and autophagy pathways by direct binding to human ATG8 modifiers. Mol Cell Biol. 2012; 32:1733-1744.

69. Salio M, Puleston DJ, Mathan TS, Shepherd D, Stranks AJ, Adamopoulou E, Veerapen N, Besra GS, Hollander GA, Simon AK, Cerundolo V. Essential role for autophagy during invariant NKT cell development. Proc Natl Acad Sci U S A. 2014; 111:E5678-687.

70. Bronietzki AW, Schuster M, Schmitz I. Autophagy in T-cell development, activation and differentiation. Immunol Cell Biol. 2015; 93:25-34.

71. Ferrando-Miguel R, Cheon MS, Lubec G. Protein levels of genes encoded on chromosome 21 in fetal Down Syndrome brain (Part V): overexpression of phosphatidyl-inositolglycan class P protein (DSCR5). Amino Acids. 2004; 26:255-261.

72. Berthelot JM, le Goff B, Maugars Y. Thymic Hassall's corpuscles, regulatory T-cells, and rheumatoid arthritis. Semin Arthritis Rheum. 2010; 39:347-355.

73. Sladowski D, Wasiutyński A, Wilczyński G, GrabskaLiberek I, Coecke S, Kinsner A, Kochanowska I. Expression of the membrane complement regulatory proteins (CD55 and CD59) in human thymus. Folia Histochem Cytobiol. 2006; 44:263-267.

74. Langbein L, Pape UF, Grund C, Kuhn C, Praetzel S, Moll I, Moll R, Franke WW. Tight junction-related structures in the absence of a lumen: occludin, claudins and tight junction plaque proteins in densely packed cell formations of stratified epithelia and squamous cell carcinomas. Eur J Cell Biol. 2003; 82:385-400.

75. Citi S, Pulimeno P, Paschoud S. Cingulin, paracingulin, and PLEKHA7: signaling and cytoskeletal adaptors at the apical junctional complex. Ann N Y Acad Sci. 2012; 1257:125132.

76. Zhang S, Konstantinidis DG, Yang JQ, Mizukawa B, Kalim K, Lang RA, Kalfa TA, Zheng Y, Guo F. Gene targeting RhoA reveals its essential role in coordinating mitochondrial function and thymocyte development. J Immunol. 2014; 193:5973-5982.

77. Yamagata N, Furuno K, Sonoda M, Sugimura H, Yamamoto K. Stomach cancer-derived del223V-226L mutation of the STCH gene causes loss of sensitization to TRAIL-mediated apoptosis. Biochem Biophys Res Commun. 2008; 376:499503.

78. Corazza N, Brumatti G, Jakob S, Villunger A, Brunner T. TRAIL and thymocyte apoptosis: not so deadly? Cell Death Differ. 2004; Suppl 2:S213-215.
79. Nagaishi T, Pao L, Lin SH, Iijima H, Kaser A, Qiao SW, Chen Z, Glickman J, Najjar SM, Nakajima A, Neel BG, Blumberg RS. SHP1 phosphatase-dependent T cell inhibition by CEACAM1 adhesion molecule isoforms. Immunity. 2006; 25:769-781.

80. Romagnani P, Annunziato F, Lazzeri E, Cosmi L, Beltrame C, Lasagni L, Chen Z, Glickman J, Najjar SM, Nakajima A, Neel BG, Blumberg RS. Interferon-inducible protein 10, monokine induced by interferon gamma, and interferoninducible T-cell alpha chemoattractant are produced by thymic epithelial cells and attract T-cell receptor (TCR) alphabeta + CD8+ single-positive T cells, TCRgammadelta+ $\mathrm{T}$ cells, and natural killer-type cells in human thymus. Blood. 2001; 97:601-607.

81. Takahashi K, Yoshida N, Murakami N, Kawata K, Ishizaki H, Tanaka-Okamoto M, Miyoshi J, Zinn AR, Shime H, Inoue N. Dynamic regulation of p53 subnuclear localization and senescence by MORC3. Mol Biol Cell. 2007; 18:17011709.

82. Li DQ, Nair SS, Kumar R. The MORC family: new epigenetic regulators of transcription and DNA damage response. Epigenetics. 2013; 8:685-693.

83. Kawasaki Y, Sagara M, Shibata Y, Shirouzu M, Yokoyama S, Akiyama T. Identification and characterization of Asef2, a guanine-nucleotide exchange factor specific for Rac1 and Cdc42. Oncogene. 2007; 26:7620-7627.

84. Guo F, Zhang S, Tripathi P, Mattner J, Phelan J, Sproles A, Mo J, Wills-Karp M, Grimes HL, Hildeman D, Zheng Y. Distinct roles of Cdc42 in thymopoiesis and effector and memory T cell differentiation. PLoS One. 2011; 6:e18002.

85. Van Campenhout CA, Eitelhuber A, Gloeckner CJ, Giallonardo P, Gegg M, Oller H, Grant SG, Krappmann D, Ueffing M, Lickert H. Dlg3 trafficking and apical tight junction formation is regulated by nedd4 and nedd4-2 e3 ubiquitin ligases. Dev Cell. 2011; 21:479-491.

86. Gay DL, Ramón H, Oliver PM. Cbl- and Nedd4-family ubiquitin ligases: balancing tolerance and immunity. Immunol Res. 2008; 42:51-64.

87. Patterson D. Molecular genetic analysis of Down syndrome. Hum Genet. 2009; 126:195-214.

88. Polimanti R, Graziano ME, Lazzarin N, Vaquero E, Manfellotto D, Fuciarelli M. GSTO1 uncommon genetic variants are associated with recurrent miscarriage risk. Fertil Steril. 2014; 101:735-739.

89. Almena M, Andrada E, Liebana R, Merida I. Diacylglycerol metabolismo attenuates $\mathrm{T}$-cell receptor signaling and alters thymocyte differentiation. Cell Death Dis. 2013; 4:e912.

90. De Los Rios P, Ben-Zvi A, Slutsky O, Azem A, Goloubinoff P. Hsp70 chaperones accelerate protein translocation and the unfolding of stable protein aggregates by entropic pulling. Proc Natl Acad Sci U S A. 2006; 103:6166-6171.

91. Finka A, Sharma SK, Goloubinoff P. Multi-layered molecular mechanisms of polypeptide holding, unfolding and disaggregation by HSP70/HSP110 chaperones. Front 
Mol Biosci. 2015; 2:29.

92. Moresco EM, Brandl K. Linking membrane trafficking and intestinal homeostasis. Tissue Barriers. 2013; 1:e23119.

93. Bizarro J, Charron C, Boulon S, Westman B, PradetBalade B, Vandermoere F, Chagot ME, Hallais M, Ahmad Y, Leonhardt H, Lamond A, Manival X, Branlant C, et al. Proteomic and $3 \mathrm{D}$ structure analyses highlight the $\mathrm{C} / \mathrm{D}$ box snoRNP assembly mechanism and its control. J Cell Biol. 2014; 207:463-480.

94. Ebert MS, Sharp PA. Roles for microRNAs in conferring robustness to biological processes. Cell. 2012; 149:515-524.

95. Liang T, Guo L, Liu C. Genome-wide analysis of mir548 gene family reveals evolutionary and functional implications. J Biomed Biotechnol. 2012; 2012:679563.

96. Sun L, Luo H, Li H, Zhao Y. Thymic epithelial cell development and differentiation: cellular and molecular regulation. Protein Cell. 2013; 4:342-355.

97. de Coo RF, Buddiger P, Smeets HJ, van Oost BA. Molecular cloning and characterization of the human mitochondrial NADH:oxidoreductase $10-\mathrm{kDa}$ gene (NDUFV3). Genomics. 1997; 45:434-437.

98. Michaud J, Kudoh J, Berry A, Bonne-Tamir B, Lalioti MD, Rossier C, Shibuya K, Kawasaki K, Asakawa S, Minoshima S, Shimizu N, Antonarakis SE, Scott HS. Isolation and characterization of a human chromosome 21q22.3 gene (WDR4) and its mouse homologue that code for a WDrepeat protein. Genomics. 2000; 68:71-79.

99. Pereira PL, Magnol L, Sahún I, Brault V, Duchon A, Prandini P, Gruart A, Bizot JC, Chadefaux-Vekemans B, Deutsch S, Trovero F, Delgado-García JM, Antonarakis SE, Dierssen M, Herault Y, et al. A new mouse model for the trisomy of the Abcg1-U2af1 region reveals the complexity of the combinatorial genetic code of Down syndrome. Hum Mol Genet. 2009; 18:4756-4769.

100. Samhan-Arias AK, Marques-da-Silva D, Yanamala N, Gutierrez-Merino C. Stimulation and clustering of cytochrome b5 reductase in caveolin-rich lipid microdomains is an early event in oxidative stress-mediated apoptosis of cerebellar granule neurons. J Proteomics. 2012; 75:2934-2949.

101. Aichinger M, Wu C, Nedjic J, Klein L. Macroautophagy substrates are loaded onto MHC class II of medullary thymic epithelial cells for central tolerance. J Exp Med. 2013; 210:287-300.

102. Sofi MH, Qiao Y, Ansel KM, Kubo M, Chang CH. Induction and maintenance of IL-4 expression are regulated differently by the 3' enhancer in CD4 T cells. J Immunol. 2011; 186:2792-2799.

103. Guedj F, Pennings JL, Wick HC, Bianchi DW. Analysis of adult cerebral cortex and hippocampus transcriptomes reveals unique molecular changes in the Ts1Cje mouse model of Down syndrome. Brain Pathol. 2015; 25:11-23.

104. Cho CK, Smith CR, Diamandis EP. Amniotic fluid proteome analysis from Down syndrome pregnancies for biomarker discovery. J Proteome Res. 2010; 9:3574-3582.

105. Kong XD, Liu N, Xu XJ. Bioinformatics analysis of biomarkers and transcriptional factor motifs in Down syndrome. Braz J Med Biol Res. 2014; 47:834-841.

106. Huttenhower C, Haley EM, Hibbs MA, Dumeaux V, Barrett DR, Coller HA, Troyanskaya OG. Exploring the human genome with functional maps. Genome Res. 2009; 19:109310106.

107. Gallo EM, Winslow MM, Canté-Barrett K, Radermacher AN, Ho L, McGinnis L, Iritani B, Neilson JR, Crabtree GR. Calcineurin sets the bandwidth for discrimination of signals during thymocyte development. Nature. 2007; 450:731-735.

108. Huang GN, Huso DL, Bouyain S, Tu J, McCorkell KA, May MJ, Zhu, Y, Lutz M, Collins S, Dehoff M, Kang S, Whartenby K, Powell J, Leahy D, Worley PF. NFAT binding and regulation of $\mathrm{T}$ cell activation by the cytoplasmic scaffolding Homer proteins. Science. 2008; 319:476-481.

109. Venancio TM, Aravind L. CYSTM, a novel cysteine-rich transmembrane module with a role in stress tolerance across eukaryotes. Bioinformatics. 2010; 26:149-152.

110. Nagahara N, Nagano M, Ito T, Shimamura K, Akimoto T, Suzuki H. Antioxidant enzyme, 3-mercaptopyruvate sulfurtransferase-knockout mice exhibit increased anxietylike behaviors: a model for human mercaptolactate-cysteine disulfiduria. Sci Rep. 2013; 3:1986.

111. Sharma S, Kaushik S, Sinha M, Kushwaha GS, Singh A, Sikarwar J, Chaudhary A, Gupta A, Kaur P, Singh TP. Structural and functional insights into peptidyl-tRNA hydrolase. Biochim Biophys Acta. 2014; 1844:1279-1288.

112. Erdodi F, Kiss E, Walsh MP, Stefansson B, Deng JT, Eto M, Brautigan DL, Hartshorne DJ. Phosphorylation of protein phosphatase type-1 inhibitory proteins by integrinlinked kinase and cyclic nucleotide-dependent protein kinases. Biochem Biophys Res Commun. 2003; 306:382338.

113. Cuttell L, Vaughan A, Silva E, Escaron CJ, Lavine M, Van Goethem E, Eid JP, Quirin M, Franc NC. Undertaker, a Drosophila Junctophilin, links Draper-mediated phagocytosis and calcium homeostasis. Cell. 2008; 135:524-534.

114. Van Goethem E, Silva EA, Xiao H, Franc NC. The Drosophila TRPP cation channel, PKD2 and Dmel/Ced-12 act in genetically distinct pathways during apoptotic cell clearance. PLoS One. 2012; 7:e31488.

115. Breuer ME, Willems PH, Smeitink JA, Koopman WJ, Nooteboom M. Cellular and animal models for mitochondrial complex I deficiency: a focus on the NDUFS4 subunit. IUBMB Life. 2013; 65:202-208.

116. Ferrer-Cortès X, Font A, Bujan N, Navarro-Sastre A, Matalonga L, Arranz JA, Riudor E, del Toro M, GarciaCazorla A, Campistol J, Briones P, Ribes A, Tort F. Protein expression profiles in patients carrying NFU1 mutations. Contribution to the pathophysiology of the disease. J Inherit 
Metab Dis. 2013; 36:841-847.

117. Grant GD, Gamsby J, Martyanov V, Brooks L 3rd, George LK, Mahoney JM, Loros JJ, Dunlap JC, Whitfield ML. Live-cell monitoring of periodic gene expression in synchronous human cells identifies Forkhead genes involved in cell cycle control. Mol Biol Cell. 2012; 23:3079-3093.

118. Hasegawa K, Martin F, Huang G, Tumas D, Diehl L, Chan AC. PEST domain-enriched tyrosine phosphatase (PEP) regulation of effector/memory T cells. Science. 2004; 303:685-689.

119. Zhang L, Mei Y, Fu NY, Guan L, Xie W, Liu HH, Yu $\mathrm{CD}$, Yin Z, Yu VC, You H.TRIM39 regulates cell cycle progression and DNA damage responses via stabilizing p21. Proc Natl Acad Sci U S A. 2012; 109:20937-20942.

120. Thomas P, Pang Y, Dong J. Enhancement of cell surface expression and receptor functions of membrane progestin receptor $\alpha(\mathrm{mPR} \alpha)$ by progesterone receptor membrane component 1 (PGRMC1): evidence for a role of PGRMC1 as an adaptor protein for steroid receptors. Endocrinology. 2014; 155:1107-1119.

121. Leposavic G, Perisic M, Pilipovic I. Role of gonadal hormones in programming developmental changes in thymopoietic efficiency and sexual diergism in thymopoiesis. Immunol Res. 2012; 52:7-19.

122. Kim W, Bennett EJ, Huttlin EL, Guo A, Li J, Possemato A, Sowa ME, Rad R, Rush J, Comb MJ, Harper JW, Gygi SP. Systematic and quantitative assessment of the ubiquitinmodified proteome. Mol Cell. 2011; 44:325-340.

123. Nguyen KD, Macaubas C, Truong P, Wang N, Hou T, Yoon T, Mellins ED. Serum amyloid A induces mitogenic signals in regulatory $\mathrm{T}$ cells via monocyte activation. Mol Immunol. 2014; 59:172-179.

124. Hayez A, Malaisse J, Roegiers E, Reynier M, Renard C, Haftek M, Geenen V, Serre G, Simon M, de Rouvroit CL, Michiels C, Poumay Y. High TMEM45A expression is correlated to epidermal keratinization. Exp Dermatol. 2014; 23:339-344.

125. Thessen Hedreul M, Möller S, Stridh P, Gupta Y, Gillett A, Daniel Beyeen A, Öckinger J, Flytzani S, Diez M, Olsson T, Jagodic M. Combining genetic mapping with genome-wide expression in experimental autoimmune encephalomyelitis highlights a gene network enriched for T cell functions and candidate genes regulating autoimmunity. Hum Mol Genet. 2013; 22:4952-4966.

126. Hallock PT, Xu CF, Park TJ, Neubert TA, Curran T, Burden SJ. Dok-7 regulates neuromuscular synapse formation by recruiting Crk and Crk-L. Genes Dev. 2010; 24:2451-2461.

127. Roy E, Togbe D, Holdorf A, Trubetskoy D, Nabti S, Küblbeck G, Schmitt S, Kopp-Schneider A, Leithäuser F, Möller P, Bladt F, Hämmerling GJ, Arnold B, et al. Fine tuning of the threshold of T cell selection by the Nck adapters. J Immunol. 2010; 185:7518-7526.

128. Borroto A, Arellano I, Dopfer EP, Prouza M, Suchànek
M, Fuentes M, Orfao A, Schamel WW, Alarcón B. Nck recruitment to the TCR required for ZAP70 activation during thymic development. J Immunol. 2013; 190:11031112.

129. Koshiba M, Apasov S, Sverdlov V, Chen P, Erb L, Turner JT, Weisman GA, Sitkovsky M. VTransient up-regulation of P2Y2 nucleotide receptor mRNA expression is an immediate early gene response in activated thymocytes. Proc Natl Acad Sci U S A. 1997; 94:831-836.

130. Glass R, Townsend-Nicholson A, Burnstock G. P2 receptors in the thymus: expression of $\mathrm{P} 2 \mathrm{X}$ and $\mathrm{P} 2 \mathrm{Y}$ receptors in adult rats, an immunohistochemical and in situ hybridisation study. Cell Tissue Res. 2000; 300:295-306.

131. Bisaggio RD, Nihei OK, Persechini PM, Savino W, Alves LA. Characterization of $\mathrm{P} 2$ receptors in thymic epithelial cells. Cell Mol Biol (Noisy-le-Grand). 2001; 47:19-31.

132. Elliott MR, Chekeni FB, Trampont PC, Lazarowski ER, Kadl A, Walk SF, Park D, Woodson RI, Ostankovich M, Sharma P, Lysiak JJ, Harden TK, Leitinger N, et al. Nucleotides released by apoptotic cells act as a find-me signal to promote phagocytic clearance. Nature. 2009; 461:282-286.

133. Boczonadi V, Määttä A. Annexin A9 is a periplakin interacting partner in membrane-targeted cytoskeletal linker protein complexes. FEBS Lett. 2012; 586:3090-3096.

134. Odaka C, Loranger A, Takizawa K, Ouellet M, Tremblay MJ, Murata S, Inoko A, Inagaki M, Marceau N. Keratin 8 is required for the maintenance of architectural structure in thymus epithelium. PLoS One. 2013; 8:e75101.

135. Adler LN, Gomez TA, Clarke SG, Linster CL. A novel GDP-D-glucose phosphorylase involved in quality control of the nucleoside diphosphate sugar pool in Caenorhabditis elegans and mammals. J Biol Chem. 2011; 286:2151121523.

136. Debily MA, Marhomy SE, Boulanger V, Eveno E, MariageSamson R, Camarca A, Auffray C, Piatier-Tonneau D, Imbeaud $\mathrm{S}$. A functional and regulatory network associated with PIP expression in human breast cancer. PLoS One. 2009; 4:e4696.

137. Savino W, Mendes-Da-Cruz DA, Smaniotto S, SilvaMonteiro E, Villa-Verde DM. Molecular mechanisms governing thymocyte migration: combined role of chemokines and extracellular matrix. J Leukoc Biol. 2004; 75:951-961.

138. Lukens JR, Gurung P, Shaw PJ, Barr MJ, Zaki MH, Brown SA, Vogel P, Chi H, Kanneganti TD. The NLRP12 Sensor Negatively Regulates Autoinflammatory Disease by Modulating Interleukin-4 Production in T Cells. Immunity. 2015; 42:654-664.

139. Gurung P, Kanneganti TD. NLRP12 in autoimmune diseases. Oncotarget. 2015; 6:19950-19951. doi: 10.18632/ oncotarget. 4585.

140. Tan X, Thapa N, Sun Y, Anderson RA. A kinaseindependent role for EGF receptor in autophagy initiation. 
Cell. 2015; 160:145-160.

141. Tan X, Sun Y, Thapa N, Liao Y, Hedman AC, Anderson RA. LAPTM4B is a PtdIns(4,5)P2 effector that regulates EGFR signaling, lysosomal sorting, and degradation. EMBO J. 2015; 34:475-490.

142. Fraisier V, Kasri A, Miserey-Lenkei S, Sibarita JB, Nair D, Mayeux A, Bardin S, Toyoda Y, Poser I, Poznyakovskiy A, Goud B, Hyman AA, Dimitrov A. C11ORF24 is a novel type I membrane protein that cycles between the Golgi apparatus and the plasma membrane in Rab6-positive vesicles. PLoS One. 2013; 8:e82223.

143. Hoff S, Halbritter J, Epting D, Frank V, Nguyen TM, van Reeuwijk J, Boehlke C, Schell C, Yasunaga T, Helmstädter M, Mergen M, Filhol E, Boldt K, et al. ANKS6 is a central component of a nephronophthisis module linking NEK8 to INVS and NPHP3. Nat Genet. 2013; 45:951-956.

144. Anitei M, Stange C, Parshina I, Baust T, Schenck A, Raposo G, Kirchhausen T, Hoflack B. Protein complexes containing CYFIP/Sra/PIR121 coordinate Arf1 and Rac1 signalling during clathrin-AP-1-coated carrier biogenesis at the TGN. Nat Cell Biol. 2010; 12:330-340.

145. Nair-Gupta P, Baccarini A, Tung N, Seyffer F, Florey O, Huang Y, Banerjee M, Overholtzer M, Roche PA, Tampé R, Brown BD, Amsen D, Whiteheart SW, et al. TLR signals induce phagosomal MHC-I delivery from the endosomal recycling compartment to allow cross-presentation. Cell. 2014; 158:506-521.

146. Kanwar N, Fayyazi A, Backofen B, Nitsche M, Dressel R, von Mollard GF. Thymic alterations in mice deficient for the SNARE protein VAMP8/endobrevin. Cell Tissue Res. 2008; 334:227-242.

147. Goetzl EJ. Hypothesis: VPAC G protein-coupled receptors for vasoactive intestinal peptide constitute a dynamic system for signaling $\mathrm{T}$ cells from plasma membrane and nuclear membrane complexes. Regul Pept. 2006; 137:7578.

148. Lara-Marquez ML, O’Dorisio MS, Karacay B. Vasoactive intestinal peptide (VIP) receptor type 2 (VPAC2) is the predominant receptor expressed in human thymocytes. Ann N Y Acad Sci. 2000; 921:45-54.

149. Giladi E, Hill JM, Dresner E, Stack CM, Gozes I. Vasoactive intestinal peptide (VIP) regulates activitydependent neuroprotective protein (ADNP) expression in vivo. J Mol Neurosci. 2007; 33:278-283.

150. Kushnir M, Dresner E, Mandel S, Gozes I. Silencing of the ADNP-family member, ADNP2, results in changes in cellular viability under oxidative stress. J Neurochem. 2008; 105:537-545.

151. Cao JY, Shire K, Landry C, Gish GD, Pawson T, Frappier L. Identification of a novel protein interaction motif in the regulatory subunit of casein kinase 2. Mol Cell Biol. 2014; 34:246-258.

152. Sestero CM, McGuire DJ, De Sarno P, Brantley EC, Soldevila G, Axtell RC, Raman C. CD5-dependent CK2 activation pathway regulates threshold for T cell anergy. $\mathrm{J}$ Immunol. 2012; 189:2918-2930.

153. Leonhardt RM, Abrahimi P, Mitchell SM, Cresswell P. Three tapasin docking sites in TAP cooperate to facilitate transporter stabilization and heterodimerization. J Immunol. 2014; 192:2480-2494.

154. Fang-Kircher SG, Labudova O, Kitzmueller E, Rink H, Cairns N, Lubec G. Increased steady state mRNA levels of DNA-repair genes XRCC1, ERCC2 and ERCC3 in brain of patients with Down syndrome. Life Sci. 1999; 64:16891699.

155. Fan L, DuPrez KT. XPB: An unconventional SF2 DNA helicase. Prog Biophys Mol Biol. 2015; 117:174-181.

156. Gegonne A, Tai X, Zhang J, Wu G, Zhu J, Yoshimoto A, Hanson J, Cultraro C, Chen QR, Guinter T, Yang Z, Hathcock K, Singer A, et al. The general transcription factor TAF7 is essential for embryonic development but not essential for the survival or differentiation of mature T cells. Mol Cell Biol. 2012; 32:1984-1997.

157. Shen F, Lin Q, Gu Y, Childress C, Yang W. Activated Cdc42-associated kinase 1 is a component of EGF receptor signaling complex and regulates EGF receptor degradation. Mol Biol Cell. 2007; 18:732-742.

158. Maroder M, Bellavia D, Vacca A, Felli MP, Screpanti I. The thymus at the crossroad of neuroimmune interactions. Ann N Y Acad Sci. 2000; 917:741-747.

159. Edelstein LC, Collins T. The SCAN domain family of zinc finger transcription factors. Gene. 2005; 359:1-17.

160. Young DJ, Stoddart A, Nakitandwe J, Chen SC, Qian Z, Downing JR, Le Beau MM. Knockdown of Hnrnpa0, a $\operatorname{del}(5 q)$ gene, alters myeloid cell fate in murine cells through regulation of AU-rich transcripts. Haematologica. 2014; 99:1032-1040.

161. Hirao K, Natsuka Y, Tamura T, Wada I, Morito D, Natsuka S, Romero P, Sleno B, Tremblay LO, Herscovics A, Nagata K, Hosokawa N. EDEM3, a soluble EDEM homolog, enhances glycoprotein endoplasmic reticulum-associated degradation and mannose trimming. J Biol Chem. 2006; 281:9650-9658.

162. Olivari S, Molinari M. Glycoprotein folding and the role of EDEM1, EDEM2 and EDEM3 in degradation of foldingdefective glycoproteins. FEBS Lett. 2007; 581:3658-3664.

163. Rocha N, Neefjes J. MHC class II molecules on the move for successful antigen presentation. EMBO J. 2008; 27:1-5.

164. Donato R, Cannon BR, Sorci G, Riuzzi F, Hsu K, Weber DJ, Geczy CL. Functions of S100 proteins. Curr Mol Med. 2013; 13:24-57.

165. Penumutchu SR, Chou RH, Yu C. Structural insights into calcium-bound S100P and the V domain of the RAGE complex. PLoS One. 2014; 9:e103947.

166. Moser B, Janik S, Schiefer AI, Müllauer L, Bekos C, Scharrer A, Mildner M, Rényi-Vámos F, Klepetko W, Ankersmit HJ. Expression of RAGE and HMGB1 in thymic epithelial tumors, thymic hyperplasia and regular thymic 
morphology. PLoS One. 2014; 9:e94118.

167. Sarang Z, Garabuczi É, Joós G, Kiss B, Tóth K, Rühl R, Szondy Z. Macrophages engulfing apoptotic thymocytes produce retinoids to promote selection, differentiation, removal and replacement of double positive thymocytes. Immunobiology. 2013; 218:1354-1360.

168. Zhang T, Park KA, Li Y, Byun HS, Jeon J, Lee Y, Hong JH, Kim JM, Huang SM, Choi SW, Kim SH, Sohn KC, Ro $\mathrm{H}$, et al. PHF20 regulates NF- $\mathrm{BB}$ signalling by disrupting recruitment of PP2A to p65. Nat Commun. 2013; 4:2062.

169. van Delft MA, Huitema LF, Tas SW. The contribution of $\mathrm{NF}-\kappa \mathrm{B}$ signalling to immune regulation and tolerance. Eur J Clin Invest. 2015; 45:529-539.

170. Jeong D, Kim JM, Cha H, Oh JG, Park J, Yun SH, Ju ES, Jeon ES, Hajjar RJ, Park WJ. PICOT attenuates cardiac hypertrophy by disrupting calcineurin-NFAT signaling. Circ Res. 2008; 102:711-719.

171. Calder PC. Branched-chain amino acids and immunity. J Nutr. 2006; 136:288S-293S.

172. Salcedo-Sicilia L, Granell S, Jovic M, Sicart A, Mato E, Johannes L, Balla T, Egea G. BIII spectrin regulates the structural integrity and the secretory protein transport of the Golgi complex. J Biol Chem. 2013; 288:2157-2166.

173. Neisch AL, Formstecher E, Fehon RG. Conundrum, an ARHGAP18 orthologue, regulates RhoA and proliferation through interactions with Moesin. Mol Biol Cell. 2013; 24:1420-1433.

174. Hirata T, Nomachi A, Tohya K, Miyasaka M, Tsukita S, Watanabe T, Narumiya S. Moesin-deficient mice reveal a non-redundant role for moesin in lymphocyte homeostasis. Int Immunol. 2012; 24:705-717.

175. Papa S, Rasmo DD, Technikova-Dobrova Z, Panelli D, Signorile A, Scacco S, Petruzzella V, Papa F, Palmisano G, Gnoni A, Micelli L, Sardanelli AM. Respiratory chain complex I, a main regulatory target of the cAMP/PKA pathway is defective in different human diseases. FEBS Lett. 2012; 586:568-577.

176. Takada H, Chen NJ, Mirtsos C, Suzuki S, Suzuki N, Wakeham A, Mak TW, Yeh WC. Role of SODD in regulation of tumor necrosis factor responses. Mol Cell Biol. 2003; 23:4026-4033.

177. Liao G, O'Keeffe MS, Wang G, van Driel B, de Waal Malefyt R, Reinecker HC, Herzog RW, Terhorst C. Glucocorticoid-Induced TNF Receptor Family-Related Protein Ligand is Requisite for Optimal Functioning of Regulatory CD4(+) T Cells. Front Immunol. 2014; 5:35.

178. Baseta JG, Stutman O. TNF regulates thymocyte production by apoptosis and proliferation of the triple negative (CD3CD4-CD8-) subset. J Immunol. 2000; 165:5621-5630.

179. Uldrich AP, Berzins SP, Malin MA, Bouillet P, Strasser A, Smyth MJ, Boyd RL, Godfrey DI. Antigen challenge inhibits thymic emigration. J Immunol. 2006; 176:45534561.

180. Werneck CC, Cruz MS, Silva LC, Villa-Verde DM, Savino
W, Mourão PA. Is there a glycosaminoglycan-related heterogeneity of the thymic epithelium? J Cell Physiol. 2000; 185:68-79.

181. Nakagawa Y, Ohigashi I, Nitta T, Sakata M, Tanaka K, Murata S, Kanagawa O, Takahama Y. Thymic nurse cells provide microenvironment for secondary $\mathrm{T}$ cell receptor $\alpha$ rearrangement in cortical thymocytes. Proc Natl Acad Sci U S A. 2012; 109:20572-20577.

182. Zhang Y, Yang Z, Cao Y, Zhang S, Li H, Huang Y, Ding YQ, Liu X. The Hsp40 family chaperone protein DnaJB6 enhances Schlafen1 nuclear localization which is critical for promotion of cell-cycle arrest in T-cells. Biochem J. 2008; 413:239-250.

183. Schwarz DA, Katayama CD, Hedrick SM. Schlafen, a new family of growth regulatory genes that affect thymocyte development. Immunity. 1998; 9: 657-668.

184. Dekker FJ, Rocks O, Vartak N, Menninger S, Hedberg C, Balamurugan R, Wetzel S, Renner S, Gerauer M, Schölermann B, Rusch M, Kramer JW, Rauh D, et al. Small-molecule inhibition of APT1 affects Ras localization and signaling. Nat Chem Biol. 2010; 6:449-456.

185. Daniels MA, Teixeiro E, Gill J, Hausmann B, Roubaty D, Holmberg K, Werlen G, Holländer GA, Gascoigne NR, Palmer E. Thymic selection threshold defined by compartmentalization of Ras/MAPK signalling. Nature. 2006; 444:724-729.

186. Veland IR, Montjean R, Eley L, Pedersen LB, Schwab A, Goodship J, Kristiansen K, Pedersen SF, Saunier S, Christensen ST. Inversin/Nephrocystin-2 is required for fibroblast polarity and directional cell migration. PLoS One. 2013; 8:e60193.

187. He F, Umehara T, Saito K, Harada T, Watanabe S, Yabuki T, Kigawa T, Takahashi M, Kuwasako K, Tsuda K, Matsuda T, Aoki M, Seki E, et al. Raducu as a histone modification reader. Structure. 2010; 18:1127-1139.

188. Raducu M, Baets J, Fano O, Van Coster R, Cruces J. Promoter alteration causes transcriptional repression of the POMGNT1 gene in limb-girdle muscular dystrophy type 2O. Eur J Hum Genet. 2012; 20:945-952.

189. Liou LY, Walsh KB, Vartanian AR, Beltran-Valero de Bernabe D, Welch M, Campbell KP, Oldstone MB, Kunz $\mathrm{S}$. Functional glycosylation of dystroglycan is crucial for thymocyte development in the mouse. PLoS One. 2010; 5:e9915.

190. Oliveira CC, Querido B, Sluijter M, de Groot AF, van der Zee R, Rabelink MJ, Hoeben RC, Ossendorp F, van der Burg SH, van Hall T. New role of signal peptide peptidase to liberate C-terminal peptides for MHC class I presentation. J Immunol. 2013; 191:4020-4028.

191. Swat W, Montgrain V, Doggett TA, Douangpanya J, Puri K, Vermi W, Diacovo TG. Essential role of PI3Kdelta and PI3Kgamma in thymocyte survival. Blood. 2006; 107:24152422.

192. Clark MC, Baum LG. T cells modulate glycans on CD43 
and CD45 during development and activation, signal regulation, and survival. Ann N Y Acad Sci. 2012; 1253:5867.

193. Gubina E, Chen T, Zhang L, Lizzio EF, Kozlowski S. CD43 polarization in unprimed $\mathrm{T}$ cells can be dissociated from raft coalescence by inhibition of HMG CoA reductase. Blood. 2002; 99:2518-2525.

194. Zingoni A, Rocchi M, Storlazzi CT, Bernardini G, Santoni A, Napolitano M. Isolation and chromosomal localization of GPR31, a human gene encoding a putative G proteincoupled receptor. Genomics. 1997; 42:519-523.

195. Gerondakis S, Fulford TS, Messina NL, Grumont RJ. NF$\kappa \mathrm{B}$ control of $\mathrm{T}$ cell development. Nat Immunol. 2014; 15:15-25.

196. Serrano-Candelas E, Alemán-Muench G, Solé-Sánchez S, Aubareda A, Martínez-Høyer S, Adán J, Aranguren-Ibáñez Á, Pritchard MA, Soldevila G, Pérez-Riba M. RCAN 1 and 3 proteins regulate thymic positive selection. Biochem Biophys Res Commun. 2015; 460:295-301.

197. Hergovich A. MOB control: reviewing a conserved family of kinase regulators. Cell Signal. 2011; 23:1433-1440.

198. Nagano T, Hashimoto T, Nakashima A, Hisanaga S, Kikkawa U, Kamada S. Cyclin I is involved in the regulation of cell cycle progression. Cell Cycle. 2013; 12:2617-2624.

199. Mulroy T, Xu Y, Sen JM. beta-Catenin expression enhances generation of mature thymocytes. Int Immunol. 2003; 15:1485-1494.

200. Gosling KM, Goodnow CC, Verma NK, Fahrer AM. Defective T-cell function leading to reduced antibody production in a kleisin-beta mutant mouse. Immunology. 2008; 125:208-217.

201. Tu Q, Yu L, Zhang P, Zhang M, Zhang H, Jiang J, Chen $\mathrm{C}$, Zhao S. Cloning, characterization and mapping of the human ATP5E gene, identification of pseudogene ATP5EP1, and definition of the ATP5E motif. Biochem J. 2000; 347 Pt 1:17-21.

202. Darshi M, Trinh KN, Murphy AN, Taylor SS. Targeting and import mechanism of coiled-coil helix coiled-coil helix domain-containing protein 3 (ChChd3) into the mitochondrial intermembrane space. J Biol Chem. 2012; 287:39480-39491.

203. Chen S, Novick P, Ferro-Novick S. ER network formation requires a balance of the dynamin-like GTPase Seylp and the Lunapark family member Lnp1p. Nat Cell Biol. 2012; 14:707-716.

204. Zhao X, Huang Z, Liu X, Chen Y, Gong W, Yu K, Qin L, Chen H, Mo D. The switch role of the Tmod4 in the regulation of balanced development between myogenesis and adipogenesis. Gene. 2013; 532:263-271.

205. Yang H, Youm YH, Sun Y, Rim JS, Galbán CJ, Vandanmagsar B, Dixit VD. Axin expression in thymic stromal cells contributes to an age-related increase in thymic adiposity and is associated with reduced thymopoiesis independently of ghrelin signaling. J Leukoc Biol. 2009; 85:928-938.

206. Bantscheff M, Hopf C, Savitski MM, Dittmann A, Grandi P, Michon AM, Schlegl J, Abraham Y, Becher I, Bergamini G, Boesche M, Delling M, Dümpelfeld B, et al. Chemoproteomics profiling of HDAC inhibitors reveals selective targeting of HDAC complexes. Nat Biotechnol. 2011; 29:255-265.

207. Razin SV, Borunova VV, Maksimenko OG, Kantidze OL. Cys2His2 zinc finger protein family: classification, functions, and major members. Biochemistry (Mosc). 2012; 77:217-226.

208. Gocke CB, Yu H. ZNF198 stabilizes the LSD1-CoRESTHDAC1 complex on chromatin through its MYM-type zinc fingers. PLoS One. 2008; 3:e3255.

209. Lefebvre V, Du Q, Baird S, Ng AC, Nascimento M, Campanella M, McBride HM, Screaton RA. Genomewide RNAi screen identifies ATPase inhibitory factor 1 (ATPIF1) as essential for PARK2 recruitment and mitophagy. Autophagy. 2013; 9:1770-1779.

210. Mukherjee D, Gao M, O’Connor JP, Raijmakers R, Pruijn G, Lutz CS, Wilusz J. The mammalian exosome mediates the efficient degradation of mRNAs that contain AU-rich elements. EMBO J. 2002; 21:165-174.

211. Markus MA, Morris BJ. RBM4: a multifunctional RNAbinding protein. Int J Biochem Cell Biol. 2009; 41:740-743.

212. Höck J, Weinmann L, Ender C, Rüdel S, Kremmer E, Raabe $\mathrm{M}$, Urlaub H, Meister G. Proteomic and functional analysis of Argonaute-containing mRNA-protein complexes in human cells. EMBO Rep. 2007; 8:1052-1060.

213. Bernert G, Fountoulakis M, Lubec G. Manifold decreased protein levels of matrin 3, reduced motor protein HMP and hlark in fetal Down's syndrome brain. Proteomics. 2002; 2:1752-1757.

214. Shi L, Song L, Fitzgerald M, Maurer K, Bagashev A, Sullivan KE. Noncoding RNAs and LRRFIP1 regulate TNF expression. J Immunol. 2014; 192:3057-3067.

215. Liepinsh DJ, Kruglov AA, Galimov AR, Shakhov AN, Shebzukhov YV, Kuchmiy AA, Grivennikov SI, Tumanov AV, Drutskaya MS, Feigenbaum L, Kuprash DV, Nedospasov SA. Accelerated thymic atrophy as a result of elevated homeostatic expression of the genes encoded by the TNF/lymphotoxin cytokine locus. Eur J Immunol. 2009; 39:2906-2915.

216. Lees JG, Bach CT, O’Neill GM. Interior decoration: tropomyosin in actin dynamics and cell migration. Cell Adh Migr. 2011; 5:181-186.

217. Lees JG, Ching YW, Adams DH, Bach CT, Samuel MS, Kee AJ, Hardeman EC, Gunning P, Cowin AJ, O’Neill GM. Tropomyosin regulates cell migration during skin wound healing. J Invest Dermatol. 2013; 133:1330-1339.

218. Devaiah BN, Lu H, Gegonne A, Sercan Z, Zhang H, Clifford RJ, Lee MP, Singer DS. Novel functions for TAF7, a regulator of TAF1-independent transcription. J 
Biol Chem. 2010; 285:38772-38780.

219. Estève PO, Terragni J, Deepti K, Chin HG, Dai N, Espejo A, Corrêa IR Jr, Bedford MT, Pradhan S. Methyllysine reader plant homeodomain (PHD) finger protein 20like 1 (PHF20L1) antagonizes DNA (cytosine-5) methyltransferase 1 (DNMT1) proteasomal degradation. J Biol Chem. 2014; 289:8277-8287.

220. Linder GE, Chuntova PD, McLelland BT, Añó L, Obodo UC, Crider NJ, Matthes DJ, García-Ojeda ME, Manilay JO, Chatterjea D. Semaphorin 4A is dynamically regulated during thymocyte development in mice. Cell Immunol. 2013; 281:150-158.

221. Mendes-da-Cruz DA, Stimamiglio MA, Muñoz JJ, Alfaro D, Terra-Granado E, Garcia-Ceca J, Alonso-Colmenar LM, Savino W, Zapata AG. Developing T-cell migration: role of semaphorins and ephrins. FASEB J. 2012; 26:4390-4399.

222. Baudet ML, Bellon A, Holt CE. Role of microRNAs in Semaphorin function and neural circuit formation. Semin Cell Dev Biol. 2013; 24:146-155.

223. Abbott CA, Yu DM, Woollatt E, Sutherland GR, McCaughan GW, Gorrell MD. Cloning, expression and chromosomal localization of a novel human dipeptidyl peptidase (DPP) IV homolog, DPP8. Eur J Biochem. 2000; 267:6140-6150.

224. Zhang H, Chen Y, Keane FM, Gorrell MD. Advances in understanding the expression and function of dipeptidyl peptidase 8 and 9. Mol Cancer Res. 2013; 11:1487-1496.

225. Klemann C, Schade J, Pabst R, Leitner S, Stiller J, von Hörsten S, Stephan M. CD26/dipeptidyl peptidase 4-deficiency alters thymic emigration patterns and leukcocyte subsets in F344-rats age-dependently. Clin Exp Immunol. 2009; 155:357-365.

226. Isono K, Fujimura Y, Shinga J, Yamaki M, O-Wang J, Takihara Y, Murahashi Y, Takada Y, Mizutani-Koseki Y, Koseki H. Mammalian polyhomeotic homologues Phc2 and Phc1 act in synergy to mediate polycomb repression of Hox genes. Mol Cell Biol. 2005; 25:6694-6706.

227. Tokimasa S, Ohta H, Sawada A, Matsuda Y, Kim JY, Nishiguchi S, Hara J, Takihara Y. Lack of the Polycombgroup gene rae28 causes maturation arrest at the early B-cell developmental stage. Exp Hematol. 2001; 29:93-103.

228. Asangani IA, Ateeq B, Cao Q, Dodson L, Pandhi M, Kunju LP, Mehra R, Lonigro RJ, Siddiqui J, Palanisamy N, Wu YM, Cao X, Kim JH, et al. Characterization of the EZH2MMSET histone methyltransferase regulatory axis in cancer. Mol Cell. 2013; 49:80-93.

229. Drumea-Mirancea M, Wessels JT, Müller CA, Essl M, Eble JA, Tolosa E, Koch M, Reinhardt DP, Sixt M, Sorokin L, Stierhof YD, Schwarz H, Klein G. Characterization of a conduit system containing laminin-5 in the human thymus: a potential transport system for small molecules. J Cell Sci. 2006; 119:1396-1405.

230. Zhou M, McPherson L, Feng D, Song A, Dong C, Lyu SC, Zhou L, Shi X, Ahn YT, Wang D, Clayberger C, Krensky
AM. Kruppel-like transcription factor 13 regulates $\mathrm{T}$ lymphocyte survival in vivo. J Immunol. 2007; 178:54965504.

231. Zahnleiter D, Hauer NN, Kessler K, Uebe S, Sugano Y, Neuhauss SC, Giessl A, Ekici AB, Blessing H, Sticht H, Dörr HG, Reis A, Thiel CT. MAP4-dependent regulation of microtubule formation affects centrosome, cilia, and Golgi architecture as a central mechanism in growth regulation. Hum Mutat. 2015; 36:87-97.

232. Kremer BE, Haystead T, Macara IG. Mammalian septins regulate microtubule stability through interaction with the microtubule-binding protein MAP4. Mol Biol Cell. 2005; 16:4648-4659.

233. Lassen LB, Füchtbauer A, Schmitz A, Sørensen AB, Pedersen FS, Füchtbauer EM. Septin9 is involved in T-cell development and CD8+ T-cell homeostasis. Cell Tissue Res. 2013; 352:695-705.

234. Kraus TF, Greiner A, Guibourt V, Kretzschmar HA. Long non-coding RNA normalisers in human brain tissue. J Neural Transm. 2015; 122:1045-1054.

235. Wevrick R, Kerns JA, Francke U. Identification of a novel paternally expressed gene in the Prader-Willi syndrome region. Hum Mol Genet. 1994; 3:1877-1882.

236. Stelzer Y, Sagi I, Yanuka O, Eiges R, Benvenisty N. The noncoding RNA IPW regulates the imprinted DLK1-DIO3 locus in an induced pluripotent stem cell model of PraderWilli syndrome. Nat Genet. 2014; 46:551-557.

237. Antoine M, Reimers K, Wirz W, Gressner AM, Müller $\mathrm{R}$, Kiefer P. Identification of an unconventional nuclear localization signal in human ribosomal protein S2. Biochem Biophys Res Commun. 2005; 335:146-153.

238. Wang M, Hu Y, Stearns ME. RPS2: a novel therapeutic target in prostate cancer. J Exp Clin Cancer Res. 2009; 28:6.

239. Schramm S, Fraune J, Naumann R, Hernandez-Hernandez A, Höög C, Cooke HJ, Alsheimer M, Benavente R. A novel mouse synaptonemal complex protein is essential for loading of central element proteins, recombination, and fertility. PLoS Genet. 2011; 7:e1002088.

240. Nelson GM, Prapapanich V, Carrigan PE, Roberts PJ, Riggs DL, Smith DF. The heat shock protein 70 cochaperone hip enhances functional maturation of glucocorticoid receptor. Mol Endocrinol. 2004; 18:1620-1630.

241. Talabér G, Boldizsár F, Bartis D, Pálinkás L, Szabó M, Berta G, Sétáló G Jr, Németh P, Berki T. Mitochondrial translocation of the glucocorticoid receptor in doublepositive thymocytes correlates with their sensitivity to glucocorticoid-induced apoptosis. Int Immunol. 2009; 21:1269-1276.

242. Chen Y, Qiao S, Tuckermann J, Okret S, Jondal M. Thymus-derived glucocorticoids mediate androgen effects on thymocyte homeostasis. FASEB J. 2010; 24:5043-5051.

243. Rafei M, Dumont-Lagacé M, Rouette A, Perreault C. Interleukin-21 accelerates thymic recovery from glucocorticoïd-induced atrophy. PLoS One. 2013; 
8:e72801.

244. Lepletier A, de Carvalho VF, Rodrigues e Silva PM, Villar S, Pérez AR, Savino W, Morrot A. Trypanosoma cruzi disrupts thymic homeostasis by altering intrathymic and systemic stress-related endocrine circuitries. PLoS Negl Trop Dis. 2013; 7:e2470.

245. Sahni N, Yi S, Zhong Q, Jailkhani N, Charloteaux B, Cusick ME, Vidal M. Edgotype: a fundamental link between genotype and phenotype. Current Opinion in Genetics \& Development. 2013; 23:649-657.

246. Perluigi M, di Domenico F, Fiorini A, Cocciolo A, Giorgi A, Foppoli C, Butterfield DA, Giorlandino M, Giorlandino $\mathrm{C}$, Schininà ME, Coccia R. Oxidative stress occurs early in Down syndrome pregnancy: A redox proteomics analysis of amniotic fluid. Proteomics Clin Appl. 2011; 5:167-178.

247. Lott IT. Antioxidants in Down syndrome. Biochim Biophys Acta. 2012; 1822:657-663.

248. Meraz-Ríos MA, Franco-Bocanegra D, Toral Rios D, Campos-Peña V. Early onset Alzheimer's disease and oxidative stress. Oxid Med Cell Longev. 2014;2014:375968.

249. Liu R, Li M, Liu ZP, Wu J, Chen L, Aihara K. Identifying critical transitions and their leading biomolecular networks in complex diseases. Sci Rep. 2012; 2:813.

250. Liu Y, Tennant DA, Zhu Z, Heath JK, Yao X, He S. DiME: a scalable disease module identification algorithm with application to glioma progression. PLoS One. 2014; 9:e86693.

251. R Development Core Team. R: A Language and environment for statistical computing. Vienna, Austria: R Foundation for Statistical Computing. 2010; Retrieved from http://www.R-project.org

252. Saeed AI, Sharov V, White J, Li J, Liang W, Bhagabati N, Braisted J, Klapa M, Currier T, Thiagarajan M, Sturn A, Snuffin M, Rezantsev A, et al. TM4: a free, open-source system for microarray data management and analysis. Biotechniques. 2003; 34:374-378.

253. Clauset A, Newman MEJ, Moore C. Finding community structure in very large networks. Phys Rev. 2004; E70:066111.

254. Costa L da F, Oliveira Jr ON, Travieso G, Rodrigues FA, Villas Boas PR, Antiqueira L, Viana MP, Correa Rocha LE. Analyzing and modeling real-world phenomena with complex networks: a survey of applications. Advances in Physics. 2011; 60:329-412.

255. Costa L da F, Rocha LEC. A generalized approach to complex networks. European Physical Journal B. 2006 ; 50:237-242.

256. Brockmann D. Human mobility and spatial disease dynamics. In: Schuster HG, editor. Reviews of Nonlinear Dynamics and Complexity. Weinheim (DE-BW), Germany: Wiley-VCH Verlag GmbH \& Co. KGaA. 2009; p:1-24.

257. Newman MEJ. Networks: An Introduction. New York: Oxford University Press. 2010; 720 p.

258. Newman MEJ, Girvan M. Finding and evaluating community structure in networks. Phys Rev E. 2004; 69:026113.

259. Blondel VD, Guillaume JL, Lambiotte R, Lefebvre E. Fast unfolding of communities in large networks. J Stat Mech. 2008; P10008.

260. Nowicki K, Snijders TAB. Estimation and Prediction for Stochastic Blockstructures. J Am Stat Assoc. 2001; 96:1077-1087.

261. Silva FN, Amancio DR, Bardosova M, Oliveira Jr ON, Costa LdaF. Using network science and text analytics to produce surveys in a scientific topic. 2015. http://arxiv.org/ abs/1506.05690.

262. Rosvall M, Bergstrom CT. Maps of random walks on complex networks reveal community structure. Proc Natl Acad Sci U S A. 2008; 105:1118-1123.

263. Larionov A, Krause A, Miller W. A standard curve based method for relative real time PCR data processing. BMC Bioinformatics. 2005; 6:62. 